
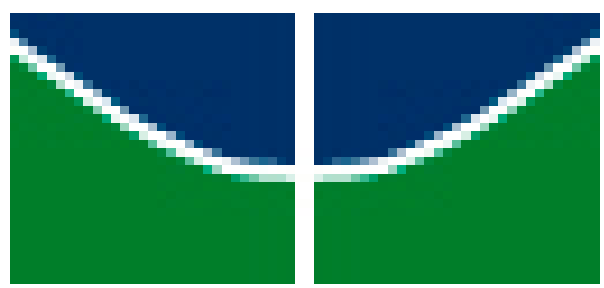

Universidade de Brasília

Departamento de Biologia Celular

Programa de Pós-Graduação em Biologia Molecular

FELIPE SILVA REDORAT

Avaliação in vitro da inibição da atividade de proteínas RAS por derivados de quinolonas no modelo câncer pancreático humano

Brasília - DF 
Avaliação in vitro da inibição da atividade de proteínas RAS por derivados de quinolonas no modelo câncer pancreático humano

Dissertação apresentada ao Programa de Pós-graduação em Biologia Molecular, do Instituto de Ciências Biológicas, da Universidade de Brasília, como parte dos requisitos necessários para a obtenção do título de Mestre em Biologia Molecular.

Orientador: Prof. Dr. José Raimundo Corrêa

Brasília - DF 


\section{Avaliação in vitro da inibição da atividade de proteínas RAS por derivados de quinolonas no modelo câncer pancreático humano}

Dissertação apresentada ao Programa de Pós-graduação em Biologia Molecular, do Instituto de Ciências Biológicas, da Universidade de Brasília, como parte dos requisitos necessários para a obtenção do título de Mestre em Biologia Molecular.

Aprovado em 31/ 03/ 2017.

BANCA EXAMINADORA

Prof. Dr. José Raimundo Corrêa (Presidente)

Prof. Dr. Carlos André Ornelas Ricart (Membro Efetivo)

Profa. Dra. Tatiane Amabile de Campos (Membro Efetivo)

Prof. Dr. Marcelo Oliveira Rodrigues (Membro Suplente) 


\section{AGRADECIMENTOS}

Agradeço primeiramente à minha família pelo apoio, compreensão, auxilio e paciência de todos esses meses, tornando-os o mais leve possível. Sem minha família nunca conseguiria ser o que sou hoje.

Ao professor José Raimundo Corrêa pela orientação, pelos enormes ensinamentos e pela paciência durante todo esse tempo.

Ao professor Brenno Amaro da Silveira Netto pela grande contribuição, colaboração e síntese dos compostos.

A todos os membros do laboratório de microscopia, pelas decisivas ajudas tanto intelectual quanto prática no auxilio do desenvolvimento do nosso projeto.

A todos os membros e ex membros do LIMPP da EMBRAPA Cenargen que me deram as primeiras orientações, críticas e consciência laboratorial, nos quais utilizo e vou utilizar para o resto da minha vida.

A todos os meus amigos, que sempre disseram que eu era uma pessoa difícil de conviver, mas nunca desistiram de mim.

À Universidade de Brasília e ao Programa de Pós-graduação em Biologia Molecular, pela oportunidade de desenvolver esse projeto.

Ao $\mathrm{CNPq}$, pelo apoio financeiro. 


\section{RESUMO}

No Brasil o câncer de pâncreas representa $2 \%$ de todos os tipos de câncer, sendo responsável por $4 \%$ do total de mortes por essa doença. Seu tratamento raramente se restringe a remoção cirúrgica do tumor devido a elevada agressividade desta doença. Para a maioria dos casos a alternativa terapêutica é a cirurgia e/ou a quimioterapia associada ou não a radioterapia. $O$ câncer de pâncreas é uma doença silenciosa com diagnóstico geralmente tardio, o que dificulta significativamente o tratamento devido a presença de metástases. Este fator também contribui decisivamente para um pobre prognóstico e uma sobrevida após o diagnóstico bastante reduzida, variando de seis a dezoito meses para um grande número de casos. As drogas de primeira escolha para serem utilizadas na quimioterapia desse tipo de câncer, Gencitabina e o 5-fluoracila (5-FU), atuam interferindo com a capacidade celular de sintetizar seu DNA, e assim inibindo a mitose e induzindo a morte celular por apoptose. Em razão dos mecanismos de ação destes fármacos causarem elevada toxicidade para todas as células, o tratamento do câncer de pâncreas está associado a diversos efeitos adversos severos como por exemplo a pancitopenia. Apesar dos avanços terapêuticos para o tratamento do câncer, o câncer de pâncreas persiste como o grande desafio, necessitando urgentemente de alternativas terapêuticas centrais e adjuvantes, que sejam eficientes na eliminação das células tumorais e tumorais com menos toxicidade para às células normais. Com base no acima exposto, nosso grupo passou a avaliar a proteína RAS mutada (KRAS), presente em mais de $40 \%$ dos casos de cânceres de pâncreas. Em seguida, nosso grupo sintetizou nove derivados de quinolonas com potencial predito computacionalmente de interferência indireta com a atividade das proteínas RAS. Desta forma, o objeto deste trabalho foi realizar a prova de conceito sobre as propriedades dos derivados das quinolonas atuarem reduzindo ou anulando a atividade anormal de KRAS, na expectativa que este potencial de inibição pudesse contribuir com a redução da taxa de proliferação celular, redução da migração celular e indução da apoptose nestas células tumorais. Embora os agentes aqui avaliados não tenham apresentado resultados promissores para o seu emprego direto, nossos resultados abrem um amplo horizonte para a síntese de outras séries de derivados das quinolonas que com elevado potencial de uso como drogas efetivas no tratamento do câncer de pâncreas.

Palavras-chave: Câncer, Pâncreas, RAS, Quimioterapia, Quinolonas. 


\section{ABSRACT}

In the Brazil, pancreatic cancer represents $2 \%$ of all cancer types. Accounting for $4 \%$ of all deaths from this disease. Its treatment is rarely restricted to the surgical removal of the tumor due to the high aggressiveness of this disease. For most cases the alternative therapy is surgery and/or chemotherapy associated or not with radiotherapy. Pancreatic cancer is a silent disease with a generally late diagnosis, which makes treatment difficult because of metastases presence. This factor also contributes decisively to a poor prognosis and a very short life after diagnosis, ranging from six to eighteen months for many the cases. The first choice drugs that are used in chemotherapy of this type of cancer, Gemcitabine and the 5-fluororacil (5-FU), act interfering with the cellular capacity to synthesize its DNA, thus inhibiting the mitosis and inducing the cell death by apoptosis. Because the mechanisms of action of these drugs cause high toxicity to all cells, the treatment of pancreatic cancer is associated with several severe adverse effects such as pancytopenia. Despite therapeutic advances in the treatment of cancer, pancreatic cancer persists as the major challenge, urgently requiring central therapeutic alternatives and adjuvants, which are efficient in eliminating tumor and tumor cells with less toxicity to normal cells. Based on the above, our group went on to evaluate the RAS protein (KRAS), changed in more than $40 \%$ of cases of pancreatic cancers. Next, our group synthesized nine quinolone derivatives with computational potential of indirectly interfering with the activity of RAS proteins. Thus, the objective of this work was to carry out the proof of concept on the properties of the quinolones derivatives to reduce or cancel the abnormal activity of KRAS, in the expectation that this potential inhibition could contribute to the reduction of the rate of cell proliferation, reduction of migration Cell and induction of apoptosis in these tumor cells. Although the agents evaluated here have not presented promising results for their direct use, our results open a wide horizon for the synthesis of other series of quinolone derivatives that with high potential of use as effective drugs in the treatment of pancreatic cancer.

Key words: Cancer, Pancreas, RAS, Chemotherapy, Quinolones. 


\section{ÍNDICE DE FIGURAS}

Figura 1. Principais eventos para a formação de uma célula tumoral.

Figura 2. Representação artística do pâncreas e sua localização, adaptado de www.ohealth.com.

Figura 3. Vias de sinalização reguladas pela proteína RAS.

Figura 4. Processo de ativação da proteína RAS.

Figura 5. Comparação entre a cascata de sinalização da proteína RAS normal e a mutada.

Figura 6. Viabilidade celular das linhagens tumorais CAPAN - 2 e PANC - 1 no período de tempo de $24 \mathrm{~h}$.

Figura 7. Viabilidade celular das linhagens tumorais CAPAN - 2 e PANC - 1 nos períodos de tempo de 48 e $72 \mathrm{~h}$.

Figura 8. Avaliação do perfil de morte celular da linhagem tumoral CAPAN - 2 tratada com os derivados de quinolonas.

Figura 9. Avaliação do perfil de morte celular da linhagem tumoral PANC-1 tratada com os derivados de quinolonas.

Figura 10. Morte celular da linhagem tumoral CAPAN - 2 tratada com os derivados de quinolonas.

Figura 11. Morte celular da linhagem tumoral PANC - 1 tratada com os derivados de quinolonas.

Figura 12. Análise morfológica das células da linhagem tumoral CAPAN - 2 tratadas com os quatro derivados de quinolonas nos períodos de tempo de 24, 48 e $72 \mathrm{~h}$.

Figura 13. Análise morfológica das células da linhagem tumoral PANC - 1 tratadas com os quatro derivados de quinolonas nos períodos de tempo de 24,48 e $72 \mathrm{~h}$.

Figura 14. Avaliação da proliferação celular de células CAPAN - 2 tratadas com os derivados de quinolonas.

Figura 15. Intensidade de fluorescência do marcador CFSE na linhagem tumoral PANC - 1 tratada com os derivados de quinolonas.

Figura 16. Índice de proliferação das linhagens tumorais CAPAN - 2 e PANC - 1 tratadas com os derivados das quinolonas.

Figura 17. Presença de Vesículas Acídicas na linhagem tumoral PANC - 1 tratada com os derivados das quinolonas.

Figura 18. Presença de Vesículas Acídicas na linhagem tumoral PANC - 1 tratada com os derivados das quinolonas.

Figura 19. Quantificação pela intensidade de fluorescência (IF) das linhagens tumorais tratadas com os derivados das quinolonas.

Figura 20. Avaliação da migração celular em células tumoral CAPAN - 2 nos intervalos de tempo de 0,12 e $24 \mathrm{~h}$. 
Figura 21. Avaliação da migração celular em células tumoral CAPAN - 2 nos intervalos de tempo de 36,48 e $60 \mathrm{~h}$.

Figura 22. Avaliação da migração celular em células tumoral CAPAN - 2 nos intervalos de tempo de $72 \mathrm{~h}$.

Figura 23. Avaliação da migração celular em células tumoral PANC - 1 nos intervalos de tempo de 0,12 e $24 \mathrm{~h}$.

Figura 24. Avaliação da migração celular em células tumoral PANC - 1 nos intervalos de tempo de 36,48 e $60 \mathrm{~h}$.

Figura 25. Avaliação da migração celular em células tumoral PANC - 1 nos intervalos de tempo de $72 \mathrm{~h}$.

Figura 26. Avaliação quantitativa da taxa de migração das células tumorais em intervalos regularesde 12 horas por um período de 72 horas sob tratamento com os derivados de quinolonas. 


\section{ÍNDICE DE TABELAS}

Tabela 1. Distribuição proporcional dos dez tipos de câncer mais incidentes estimados para 2016 por sexo, exceto pele não melanoma* (INCA, 2016). 05

Tabela 2. Prevalência dos diferentes tipos de mutação da proteína RAS nos órgãos. $\quad 14$

Tabela 3. Compostos utilizados no presente trabalho com suas respectivas Fórmulas

Estruturais, Fórmulas Moleculares e Massas Molares. 


\section{LISTA DE ABREVEATURAS E SIGLAS}

\begin{tabular}{|c|c|}
\hline 3-MA & 3-Metiladenina \\
\hline $5-\mathrm{FU}$ & 5-Fluoracila \\
\hline APC & Complexo promotor da anáfase \\
\hline ATP & Adenosina trifosfato \\
\hline BRCA1 & Proteína do tipo 1 de susceptibilidade ao câncer de mama \\
\hline BRCA2 & Proteína do tipo 2 de susceptibilidade ao câncer de mama \\
\hline BSA & Albumina Sérica Bovina \\
\hline CFSE & Éster carboxifluoresceína succinimidil \\
\hline $\mathrm{CO}_{2}$ & Dióxido de carbono \\
\hline СТT & Célula-tronco tumoral \\
\hline DCC & Deleted in Colorectal Carcinoma \\
\hline DMEM & Meio de Eagle modificado por Dulbecco \\
\hline DMSO & Dimetilsulfóxido \\
\hline DNA & Ácido Desoxirribonucleico \\
\hline EDTA & Ácido etilenodiamino tetra-acético \\
\hline EFG & Fator de crescimento epidérmico \\
\hline HER2 & Receptor do fator de crescimento epidermal humano 2 \\
\hline HER3 & Receptor do fator de crescimento epidermal humano 3 \\
\hline HER4 & Receptor do fator de crescimento epidermal humano 4 \\
\hline HGF & Fator de crescimento do hapatócio \\
\hline HT-29 & Linhagem celular de adenocarcinoma colorretal \\
\hline $\mathrm{IC}_{50}$ & Concentração Inibitória de 50\% \\
\hline INCA & Instituto Nacional do Câncer \\
\hline K-RAS & Homólogo do oncogene viral do sarcoma de rato v-Ki-ras2 Kirsten \\
\hline MCR & Reação Multicomponente (Multicomponente Reaction) \\
\hline MGMT & Metiltransferase metilada-DNA-proteína-cisteína \\
\hline MLH1 & MutL Homologo 1 \\
\hline MTT & Brometo de 3-(4,5-dimetiltiazol-2-il)-2,5-difeniltetrazolium multidrogas \\
\hline NT & Não tratado \\
\hline$\stackrel{\circ}{\circ}$ & Graus Celsius \\
\hline OMS & Organização Mundial de Saúde \\
\hline p16 & inibidor de CDK \\
\hline p53 & Proteína reguladora do ciclo celular e supressora de tumor \\
\hline PanIN-2 & Pancreatic intraepithelial neoplasia 2 \\
\hline PanIN-3 & Pancreatic intraepithelial neoplasia 3 \\
\hline PBS & Tampão Fosfato Salina \\
\hline $\mathrm{PI}$ & lodeto de Propídio (Propidium lodide) \\
\hline Rapa & Rapamicina \\
\hline
\end{tabular}


RE Retículo endoplasmático

RNA Ácido ribonucleico

SDS Dodecil sulfato de sódio

SFB Soro fetal bovino

SMAD4 Proteína homóloga mãe contra decapentaplégico 4

TGF- $\beta \quad$ Fator transformador do crescimento $\beta$

VEGF Fator de crescimento endotelial vascular

WHO World Health Organization 
SUMÁRIO

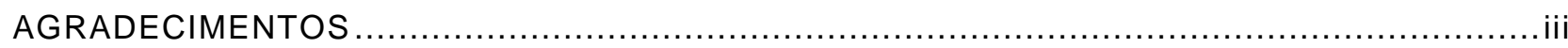

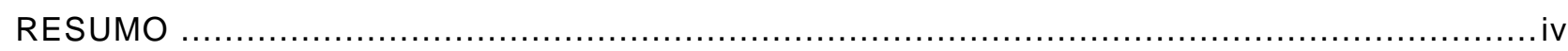

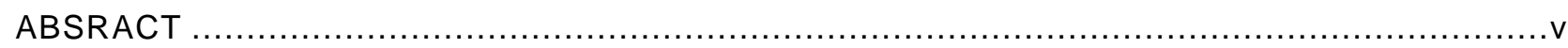

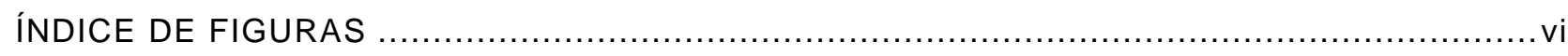

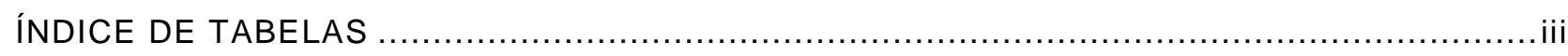

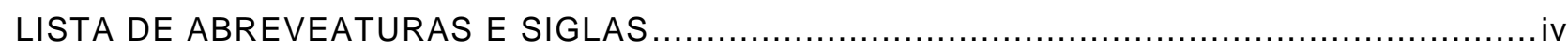

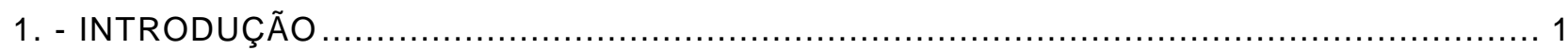

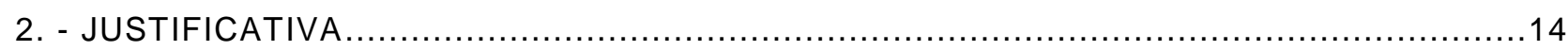

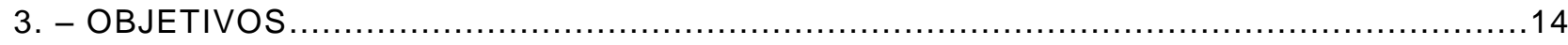

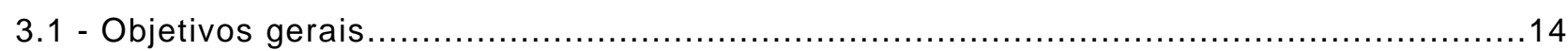

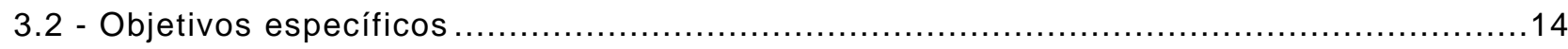

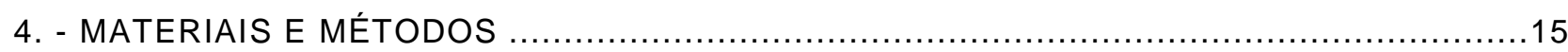

4.4 - Desenho experimental de testes dos derivados das quinolonas ...........................17

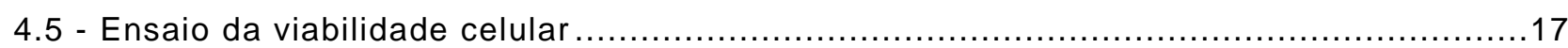

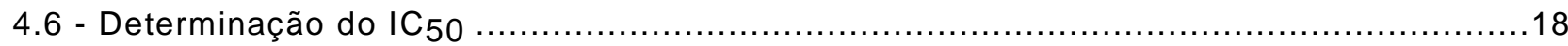

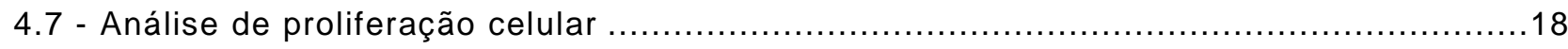

4.8 - Caracterização da morte celular induzida pelos derivados das quinolonas ..................18

4.9 - Análise de presença de vesículas acídicas ..................................................... 19

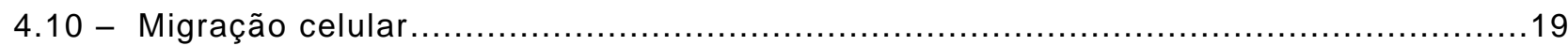

4.11 - Avaliações morfológicas das células tumorais tratadas com os derivados das

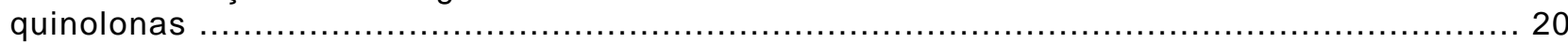

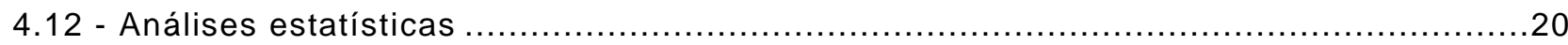

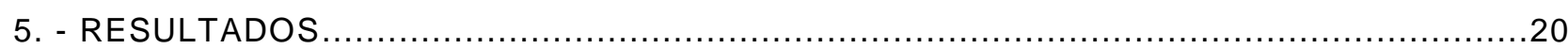

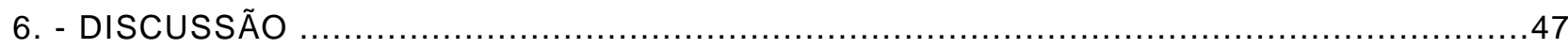

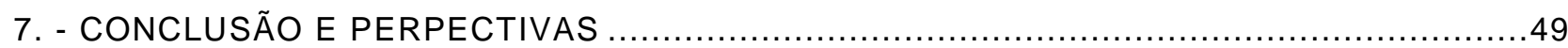

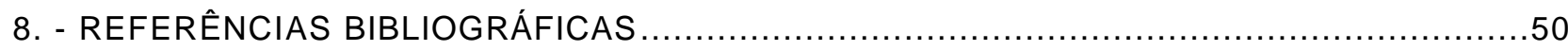




\section{1. - INTRODUÇÃO}

\section{O Câncer}

A proliferação, diferenciação e morte programada das células, são eventos comuns, frequentes e necessários para o funcionamento normal do organismo. Quando o controle da taxa de proliferação celular e da morte celular programa são perdidos, geram uma condição anormal produzindo uma população celular imortalizada e com elevada taxa de replicação. A esta população celular que se desenvolve de forma adjacente ao tecido normal define-se como neoplasias (KIRCHNER, 2014; BIRBRAIR et al., 2014; UHR et al., 2015; CHENG, 2016). As neoplasias podem ser classificadas em benigna (crescimento restrito ao local de surgimento, lento e expansivo), pré-maligna (carcinoma in situ, não invasiva, porém propensa a se transformar em maligna), e maligna (crescimento rápido e invasivo de extratos no mesmo tecido e de outros tecidos adjacentes ou distantes da região de seu surgimento através do processo de metástase) (ABRAMS, 2012, WHO, 2014; INCA, 2016).

O surgimento do câncer depende de diversos eventos abrangentes e complexos, controlados por fatores genéticos e epigenéticos, que induzem mutações e/ou descontrole da expressão e regulação gênica, o que leva a alterações irreversíveis da homeostase celular. Esta condição se traduz em proliferação acelerada e descontrolada, inibição dos processos naturais de morte celular, perda da inibição por contato, mudanças no metabolismo normal, incapacidade de adesão de células justapostas, capacidade de migração para outros tecidos e propriedades de modulação do sistema imunológico. Todas estas modificações impedem que estas células possam desempenhar suas funções teciduais normais comprometendo também a atividade do órgão onde se originam (GRIFFITHS et al., 2006, STYLIANOPOULOS, 2016; SINGH et al., 2017; SUN; ZHANG; MA, 2014). Dentre os principais fatores epigenéticos relacionados ao surgimento do câncer, temos as modificações dos padrões de metilação do DNA e das acetilações e fosforilações das histonas que podem inibir, ativar ou ainda promover a super expressão de genes primordiais a manutenção da fisiologia normal das células (NOVAK, 2004; LOKODY, 2013; SETON-ROGERS, 2013). Inúmeros genes que regulam o sistema de reparo de DNA e o ciclo celular estão sujeitos a mudanças epigenéticas o que pode acarretar em sua transformação para célula tumoral (COLEMAN, 2016; MCCARREY, 2016). Dentre as modificações mais observadas podemos citar a hipermetilação dos seguintes elementos gênicos: (a) complexo promotor da anáfase (APC), (b) p53 (proteína reguladora do ciclo celular e supressora de tumor), (c) 6-Metilguanina-DNA Metiltransferase (MGMT), MutL Homologo 1 (MLH1), Breast Câncer 1 (BRCA1) todos genes ligados ao reparo do DNA, e (d) p16 (inibidor de CDK). Esta hirpermetilação promove o silenciamento transcricional destes genes levando a célula a perder o controle de seu ciclo celular e estabelecendo o seu estado transformado (JONES, BAYLIN, 2002; GOMES et al., 2014; LI et al., 2014, MANTRIPRAGADA et al., 2015; GAO et al., 2016; SZOPA et al., 2017).

Diversas são as fontes que podem levar a mutações no material genético e que contribuem para o desenvolvimento do câncer, geralmente são apresentadas como fontes 
externas, como exposição a radiações ionizantes, substâncias químicas, ou infecções virais e outros organismos patogênicos. Fontes internas podem ser representadas pela desregulação hormonal, propensão genética hereditária e imunodeficiência (AMERICAN CANCER SOCIETY, 2016; INCA, 2016). Com o estabelecimento das mutações, diversas mudanças metabólicas e fisiológicas ocorrem nas células, que passam do seu estado normal para o estado tumoral, em seguida estas células geram o tecido tumoral o qual devido a instabilidade genética destas células é totalmente heterogêneo e incompatível ao tecido original (DRY; YANG; SAEZRODRIGUEZ, 2016; TIROSH et al., 2016; MEACHAM; MORRISON, 2014). O metabolismo acelerado, super expressão de receptores ligados a captação de macromoléculas, e o estado indiferenciado de subpopulações celulares, traz diversas vantagens competitivas para este tecido, permitindo uma melhor adaptação, sobrevivência e exploração dos recursos de forma mais eficiente que as células normais (DRY; YANG; SAEZ-RODRIGUEZ, 2016; MEACHAM; MORRISON, 2014). Estas diferenças ainda contribuem para a comunicação entre as células tumorais e as células do sistema imune, o que leva ao organismo tolerar este tecido. Além disso, a medida que o tecido tumoral se desenvolve, inicia-se o seu processo de angiogênese através do qual ocorre a indução da ligação de vasos do organismo aos vasos do tumor iniciando o complexo sistema de suprimento necessário para o desenvolvimento do tumor, o que posteriormente também contribuirá para metástase tumoral (HANAHAN; WEINBERG, 2011, ADAMSON, 1987; WEINBERG, 2006; MENG, 2012; TODD. WONG, 1999; WEINSTEIN, JOE, 2006).

O processo de metástase compreende na propriedade das células tumorais de migrar pelo tecido, invadir vasos sanguíneos e linfáticos, se espalhar pelo organismo, encontrar um tecido alvo, migrar novamente do vaso para o tecido, estabelecendo tumores secundários, geralmente distantes do tumor primário (FIDLER, 2003). A metástase é dependente de diversos processos celulares incomuns em células diferenciadas, como o remodelamento do citoesqueleto, substituição de proteínas de adesão, migração, expressão e secreção de metaloproteinases (ZHAO, 2014; KUMAR et al., 2017). A metástase não apenas tipifica o câncer como maligno, mas também está diretamente associada com a gravidade da doença, servindo ainda como parâmetro para o estadiamento dos diversos tipos de cânceres humanos (FRIEDL; ALEXANDER, 2011, CHAMBERS et al., 2002; FRIEDL; WOLF, 2003; SAHAI, 2007). Na figura 1 estão sumarizados os principais eventos que levam ao estabelecimento do câncer, Hanahan and Weinberg, 2011. 


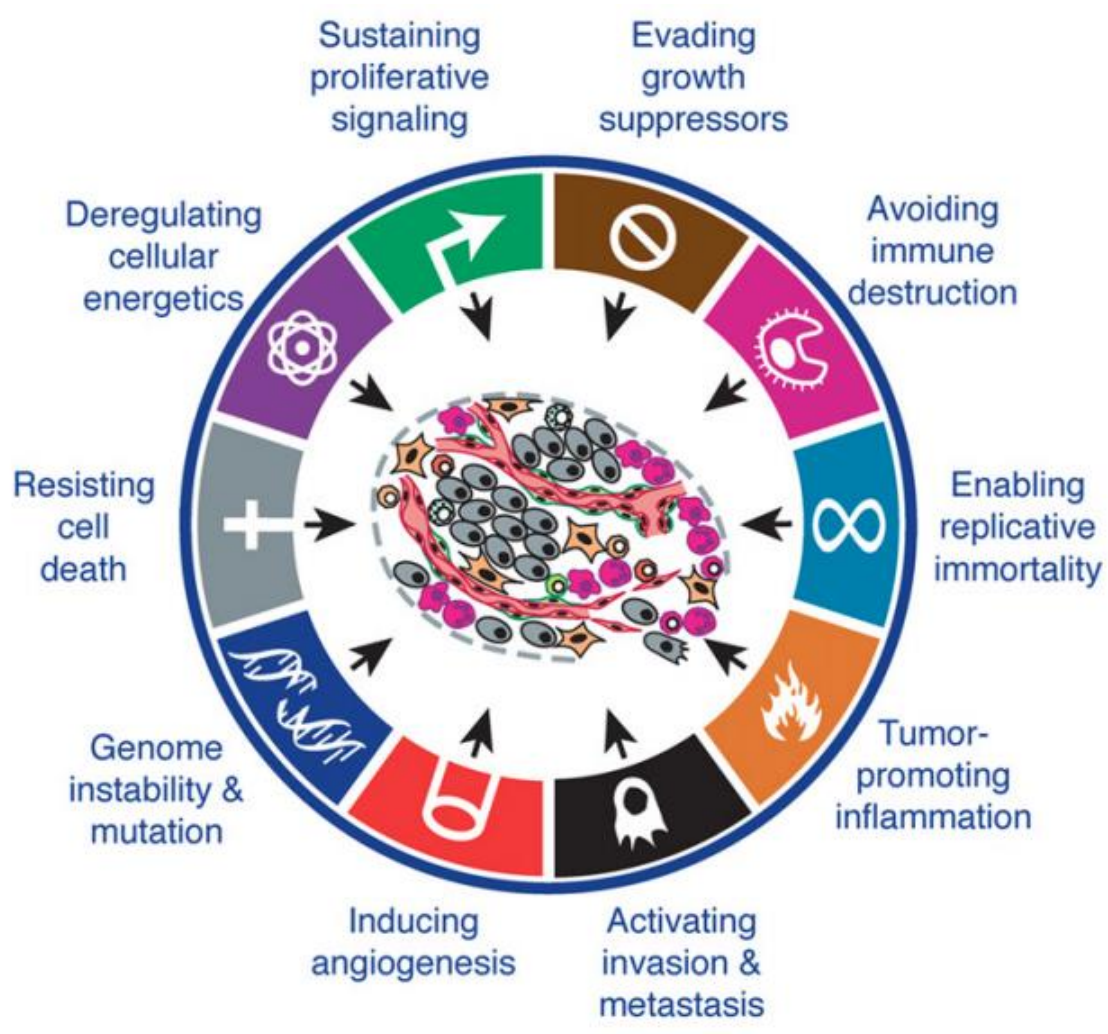

Figura 1. Principais eventos para a formação de uma célula tumoral. As principais características de adquiridas por uma célula tumoral são a perda se supressores de crescimento, prevenção da destruição imune, capacidade de imortalidade replicativa, inflamação promovida pelo tumor, ativação da invasão e da metástase, indução de angiogênese, instabilidade genômica e alta taxa d mutação, alta resistência aos tipos de morte celular, desregulação do metabolismo energético e fisiológico, manutenção constante da sinalização proliferativa (Hanahan and Weinberg, 2011).

O câncer, por ter inúmeras características singulares e dependentes de diversos fatores pode ser classificado de diversas formas dentre elas a histológica, ou seja, de acordo com o tipo de tecido no qual o câncer é originado. Esta classificação é subdividida em seis categorias (carcinoma, linfoma, mieloma, leucemia, sarcoma, e tipos mistos) (KANDOTH, 2013; SEER, 2014). O carcinoma é o tipo mais comum do câncer e é caracterizado de duas maneiras, os adenocarcinomas (situados em tecido glandular) e carcinomas de células escamosas (pertencentes ao epitélio escamoso) (TRAVIS, 1999; DABBS, SILVERMAN, 2001).

Através de análises estatísticas apresentadas pela Internacional Agency of Research on Cancer ( $\operatorname{larc}$ ), administrados pela Organização Mundial da Saúde (OMS), no ano de 2014, o câncer foi considerado um problema de saúde de escala mundial, afetando não só países em desenvolvimento, mas também países desenvolvidos (INCA, 2016; GLOBOCAN, 2012). Nos países em desenvolvimento, o aumento desta doença está relacionado ao controle ineficiente das exposições a fatores de risco, diagnósticos tardios da doença, redução na taxa de mortalidade causada por doenças infecciosas e pela diminuição considerável da mortalidade 
infantil. No caso de países desenvolvidos, o aumento de novos casos de câncer deve-se aos fatores ligados ao envelhecimento, obesidade, sedentarismo, crescimento populacional e aumento do consumo de substâncias cancerígenas (INCA, 2016; JEMAL et al., 2011).

Cerca de 14 milhões de novos casos de câncer com 8 milhões de óbitos, em 2012, foram preditos pela larc/GLOBOCAN, sendo que dos quais $60 \%$ (8,4 milhões) ocorreram em países em desenvolvimento com uma taxa de $70 \%$ de óbito (5,88 milhões). Em homens, a frequência de casos de câncer é maior do que em mulheres, cerca de $25 \%$ a mais, com um índice de mortalidade de $15 \%$ para homens e $8 \%$ para mulheres, comparando com países desenvolvidos (dados esses não aplicados para câncer de pele não melanoma) (FERLAY, 2013; INCA, 2016; GLOBOCAN, 2012). Os tipos mais frequentes de câncer no mundo são: pulmão (1,8 milhão), mama (1,7 milhão), intestino (1,4 milhão) e próstata (1,1 milhão). Em homens, as incidências são de pulmão $(16,7 \%)$, próstata (15\%), intestino $(10 \%)$, estômago $(8,5 \%)$, e fígado $(7,5 \%)$. Já em mulheres as incidências são mama $(25,2 \%)$, intestino $(9,2 \%)$, pulmão $(8,7 \%)$, colo do útero $(7,9 \%)$ e estômago $(4,8 \%)$. Mais de 20 milhões de novos casos de câncer com taxa de mortalidade de mais de 13 milhões são estimados para 2025 de acordo com a OMS (INCA, 2016).

No Brasil mais de 570 mil novos casos de câncer, exceto os de pele não melanoma, foram estimados para o ano de 2014, com frequência de $52 \%$ em homens com as maiores taxas de incidência de sítios primários na próstata, pulmão e cólon, e 48\% em mulheres nas maiores frequências em mama, cólon e útero (INCA, 2016). Em 2016-2017, os estudos apontam um aumento desse número para 600 mil novos casos de câncer (excluindo de pele não melanoma, cerca de 180 mil novos casos) com uma incidência de próstata $(28,6 \%)$, pulmão $(8,1 \%)$, intestino $(7,8 \%)$, estômago $(6 \%)$ e cavidade oral $(5,2 \%)$ em homens. No caso das mulheres mama $(28,1 \%)$, intestino $(8,6 \%)$, colo do útero $(7,9 \%)$, pulmão $(5,3 \%)$ e estômago $(3,7 \%)$ conforme pode ser observado na tabela 1 (INCA, 2016).

Tabela 1. Distribuição proporcional dos dez tipos de câncer mais incidentes estimados para 2016 por sexo, exceto pele não melanoma* (INCA, 2016).

\begin{tabular}{|c|c|c|c|c|c|c|c|}
\hline Localização Primária & Casos & $\%$ & & & Localização Primária & Casos & $\%$ \\
\hline Próstata & 61.200 & $28,6 \%$ & Homens & Mulheres & Mama feminina & 57.960 & $28,1 \%$ \\
\hline Traqueia, Brônquio e Pulmão & 17.330 & $8,1 \%$ & & & Cólon e Reto & 17.620 & $8,6 \%$ \\
\hline Cólon e Reto & 16.660 & $7,8 \%$ & & & Colo do útero & 16.340 & $7,9 \%$ \\
\hline Estômago & 12.920 & $6,0 \%$ & & & Traqueia, Brônquio e Pulmão & 10.890 & $5,3 \%$ \\
\hline Cavidade Oral & 11.140 & $5,2 \%$ & & & Estômago & 7.600 & $3,7 \%$ \\
\hline Esôfago & 7.950 & $3,7 \%$ & & & Corpo do útero & 6.950 & $3,4 \%$ \\
\hline Bexiga & 7.200 & $3,4 \%$ & & & Ovário & 6.150 & $3,0 \%$ \\
\hline Laringe & 6.360 & $3,0 \%$ & & & Glândula Tireoide & 5.870 & $2,9 \%$ \\
\hline Leucemias & 5.540 & $2,6 \%$ & & & Linfoma não Hodgkin & 5.030 & $2,4 \%$ \\
\hline Sistema Nervoso Central & 5.440 & $2,5 \%$ & & & Sistema Nervoso Central & 4.830 & $2,3 \%$ \\
\hline
\end{tabular}

*Números arredondados para múltiplos de 10. 


\section{O Câncer de pâncreas}

O pâncreas é uma glândula exócrina e endócrina localizada na parte superior do abdome e atrás do estômago. Possui a forma de gancho e é dividido em três segmentos, a cabeça (lado direito do órgão, encostando-se ao duodeno), o corpo (seção central) e a cauda (lado esquerdo do órgão), figura 2. É responsável pela produção de enzimas, que atuam na digestão dos alimentos (exócrino), e por hormônios que regulam os níveis de glicose no sangue (endócrino) (BRAGA, 2014).

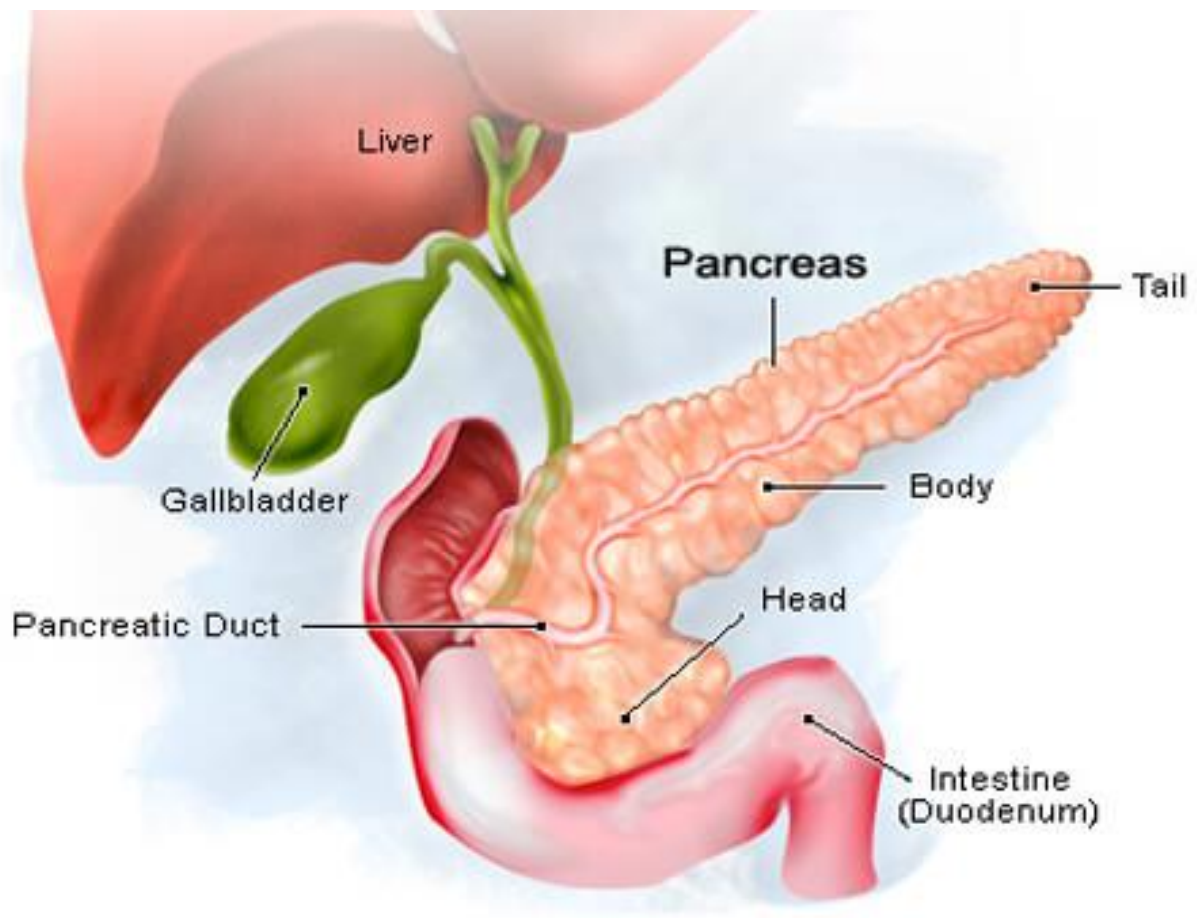

Figura 2. Representação artística do pâncreas e sua localização, adaptado de www.ohealth.com.

O câncer de pâncreas é pouco comum antes dos 30 anos de idade, tendo seu pico de prevalência a partir dos 60 anos de idade. Segundo a União Internacional Contra o Câncer (UICC), os casos da doença aumentam com o avanço da idade: de 10/100.000 casos entre 40 e 50 anos para 116/100.000 entre 80 e 85 anos. No Brasil, o câncer de pâncreas representa $2 \%$ de todos os tipos de câncer, sendo responsável por $4 \%$ do total de mortes por câncer (INCA, 2016). Por ano, nos Estados Unidos, mais de 25 mil pessoas são diagnosticadas com essa doença, é o $11^{\circ}$ com maior prevalência estando em $4^{\circ}$ lugar na frequência de mortalidade para homens, atrás de próstata, pulmão e cólon. A maior parte dos casos da doença localiza-se na região da cabeça do órgão e é diagnosticada em fase avançada, portanto é tratada apenas para fins paliativos (BRAGA, 2014). Os tipos mais frequentes são os exócrinos, dentre eles o adenocarcinoma com $90 \%$ dos casos (na região direita do órgão, a cabeça). Os neuroendócrinos (no corpo e na cauda do órgão, regiões centrais e a esquerda do órgão, 
respectivamente) são os tipos mais incomuns, porém com um prognóstico melhor aos pacientes (INCA, 2016).

Esse tipo de câncer é uma doença grave com sintomas iniciais inespecíficos e podem ser confundidos com manifestações de outras enfermidades. Por não apresentar sinais típicos, e com sintomatologia tardia o seu diagnóstico precoce não é comum. Os sintomas dependem da região onde está localizado o tumor, e os mais perceptíveis são perda de apetite e de peso, fraqueza, diarreia, tontura, dor abdominal de leve a intensa que irradia para as costas, icterícia, anemia e diabetes tipo 2 (AMERICAN CANCER SOCIETY, 2016). Infelizmente, alguns desses sinais podem indicar que as células malignas já invadiram a corrente sanguínea e já se estabeleceram em órgãos vizinhos (metástase). Nesses casos, a doença pode estar numa fase mais avançada sendo mais difícil o tratamento (AMERICAN CANCER SOCIETY, 2016).

O diagnóstico do câncer de pâncreas leva em conta os sinais, sintomas, avaliações de imagens do órgão somadas a análise de resultados de exames de laboratório como hemograma, uréia, creatinina, glicemia, coagulograma, bilirrubina total e frações (BTF), enzimas hepáticas e canaliculares, amilase, lípase, tipagem sanguínea, cromogranina A (marcador tumoral utilizado em neoplasias endócrinas), antígeno carcinoembrionário (CEA, presentes em mais de $60 \%$ dos casos de neoplasia pancreática), CA 72.4 (conhecido como TAG - 72, com taxa de sensibilidade de $45 \%$ para neoplasia pancreática, utilizado para controle de remissão e recidiva de carcinoma), CA 50 (antígeno de glicoproteína que é expresso pela maioria dos carcinomas epiteliais e CA19.9 (antígeno de glicoproteína de superfície celular, alterado em mais de $90 \%$ dos casos de neoplasia pancreática (ALMEIDA et al, 2007; MARCHI; PAIELLA; LUCHINI, 2016; HOLDENRIEDER et al. 2016; PRESS, 2016; KAUR et al., 2016). O CA 19.9 é de grande importância no acompanhamento da doença e valor limitado na triagem, pois de 10 a $15 \%$ dos indivíduos não secretam esta glicoproteína (não possuem o gene de Lewis) e tumores pequenos e assintomáticos geralmente têm níveis normais de CA 19.9. Além disso, seus níveis podem estar aumentados em patologias benignas das vias biliares e pancreáticas (ALMEIDA et al., 2007).

O acompanhamento por imagens, tais como ultrassonografia, tomografia computadorizada, ressonância magnética e a colangiopancreatografia retrógrada endoscópica são metodologias utilizadas como auxiliares na avaliação da resposta a quimioterapia, por apresentarem limitações na identificação do tecido alvo. Em alguns casos, é preciso realizar uma biópsia para ter-se um diagnóstico conclusivo (INCA, 2016; ALMEIDA et al., 2007).

O tratamento do câncer de pâncreas pressupõe, sempre que possível, uma cirurgia para a retirada completa do tumor. Quando já existem focos de metástases prejudicando o funcionamento de outros órgãos, ela ainda pode ser realizada para reduzir os sintomas adversos causados pela doença. A quimioterapia, associada ou não à radioterapia, é o recurso terapêutico utilizado para controle da doença ou alívio dos sintomas e para evitar recidivas do tumor, (AMERICAN CANCER SOCIETY, 2016). Como normalmente o diagnóstico dos casos de câncer de pâncreas é tardio, ponto em que a doença já apresenta metástase, as chances de cura são de praticamente zero mesmo com todos os tratamentos existentes. É comum se adotar uma conduta de tratamento paliativo, em busca sobrevida e qualidade de vida destes pacientes 
(AMERICAN CANCER SOCIETY, 2016).

O tabagismo, o consumo de bebidas alcóolicas, alimentos industrializados, bem como ocorrência da pancreatite crônica, diabetes, histórico familiar de câncer, e submissão a procedimentos cirúrgicos para o tratamento de úlcera no estômago e/ou duodeno e retirada de vesícula biliar, são fatores de risco que contribuem fortemente para formação das neoplasias pancreáticas (INCA, 2016).

Atualmente os agentes quimioterápicos de escolha para o tratamento do câncer de pâncreas são: Cisplatina, 5-Fluorouracila (5 - FU) e Gemcitabina (UCHIHARA et al., 2015). Essas drogas ou interferem com a síntese de DNA, ou no caso da cisplatina devido a sua associação com o DNA, originando ligações intra e intercadeias, as quais induzem alterações estruturais no material genético. O seu efeito citotóxico é devido a inibição da transcrição e replicação, induzindo as células a morte por apoptose (CHAO et al., 2014; HUANG et al., 2016). No entanto, este esquema de tratamento é altamente inespecífico, produzindo intensa citotoxicidade o que gera diversos efeitos adversos nocivos aos pacientes como pancitopenia, diarréia severa, alopecia, hemorragias, dentre outros.

O adenocarcinoma pancreático vem sendo associado a três tipos de disfunções genéticas: (1) ativação de oncogenes promotores de proliferação celular, (2) inativação de genes supressores de tumor e (3) expressão excessiva de fatores de crescimento e/ou seus receptores (YU et al.,2014; NORRIS et al.,2013). Um fator genético muito importante para o estabelecimento do câncer no pâncreas são mutações no gene supressor tumoral p53 (YU et al., 2014). Este evento genético é o mais comum em todos os tipos de cânceres humanos, e é observado em $75 \%$ dos cânceres pancreáticos. Este gene codifica uma fosfoproteína nuclear de 53-kD que tem um papel importante na regulação do ciclo celular, síntese e reparo de DNA, apoptose e diferenciação celular (YU et al., 2014; NORRIS et al., 2013). Apesar de mutações do gene p53 resultarem em perda da sua função, as mutações do gene p53 isoladas não são suficientes para causar transformação maligna (YU et al., 2014; NORRIS et al., 2013).

Mutações que resultam em perda funcional de outros genes supressores de tumor, incluindo p16, SMAD-4 (SMAD familymember4), e DCC (Deleted in Colorectal Carcinoma) são comumente observadas em cânceres pancreáticos (YU et al., 2014; NORRIS et al., 2013). Deleções, muito menos frequentes de genes de supressão tumoral, foram observadas em cânceres pancreáticos resultando na perda do gene de retinoblastoma e do gene da polipose adenomatosa coli (APC). Há relatos na literatura que genes de reparo do DNA sofrem mutação e são funcionalmente excluídos em cânceres pancreáticos. Esses genes codificam enzimas reparadoras de alterações potencialmente patológicas que ocorrem durante a replicação do DNA (YU et al., 2014; NORRIS et al., 2013).

Muitos fatores de crescimento são supra regulados no câncer pancreático, ou por aumento da expressão de seus receptores ou ainda por aumento nos seus ligantes. As alterações mais comumente observadas envolvem a família do receptor do fator de crescimento epidérmico (EGF) (DI LEO et al., 2002, RIESCO et al., 2017), que inclui o receptor de EGF (que responde ao EGF e ao fator transformador de crescimento-alfa) e os receptores HER2, HER3 e HER4 (LIZARAZO; IVÁN, 2008, CHEN et al., 2017). A expressão excessiva dos receptores de 
EGF e seus ligantes é associada à agressividade do tumor, maior potencial para metástase e um mau prognóstico (DI LEO et al., 2002, RIESCO et al., 2017). O aumento da expressão do HER2 é associado a maior diferenciação fenotípica (CHEN et al, 2017). Outros sistemas de fator de crescimento implicados no desenvolvimento de câncer pancreático incluem aqueles de crescimento do hepatócito (HGF) e para transformação de crescimento do fator-p (TFG- $\beta$ ) (RUCKI et al., 2016; MELCHIONNA et al., 2016). Alterações no p16 são encontradas primariamente no PanIN-2 e PanIN-3 (Pancreatic intraepithelial neoplasia, grade 2/3) (MIYAZAKI et al., 2017; ZHU et al., 2015). DPC4, BRCA2 e p53 são inativados durante os estágios tardios de progressão deste tipo câncer e são encontrados quase exclusivamente em lesões invasivas (DI LEO et al., 2002, STOJANOVIC et al., 2015).

\section{Proteína RAS}

O nome RAS é derivado do inglês "RAt Sarcoma vírus" devido a um tipo de sarcoma de rato ter origem em uma infecção viral. Nestes sarcomas foi observado o desequilíbrio na função de controle da divisão celular (MALUMBRES; BARBACID, 2003). Os dois primeiros genes RAS identificados foram HRAS e KRAS, resultantes de estudos com dois tipos de câncer causados por viroses, denominados de Harvey sarcoma virus e Kirsten sarcoma virus. Estudos estes realizados por Edward $\mathrm{M}$. Scolnick e colaboradores no National Institutes of Health (NIH) (CHANG et al., 1982). Estes vírus foram originalmente identificados em ratos durante a década de 60 por Jennifer Harvey (HARVEY, 1964) e Werner Kirsten, (KIRSTEN et al., 1970).

O interesse pelas proteínas RAS intensificou-se a partir de 1982, quando mutações nos genes RAS foram implicadas no desenvolvimento de câncer em humanos (COOPER, 1982). A seguir a importância da proteína RAS na sinalização intracelular foi elucidada por meio de experimentos com microinjeção de RAS ativa e anticorpos anti-RAS, mostrando que RAS não é somente capaz de induzir o crescimento anormal característico de células de câncer, mas é necessária para a resposta de células normais à estimulação por fatores de crescimento (LUNKE et al., 2017, VARGA et al., 2017). RAS é uma proteína pertencente a família das proteínas $G$ que participam de inúmeras cascatas de ativação por transdução de sinal com atividade GTPásica intrísica promovendo proliferação, crescimento, sobrevivência, diferenciação e migração celular (Figura 3) (BERNDT; AMILTON; SEBTI, 2011). 


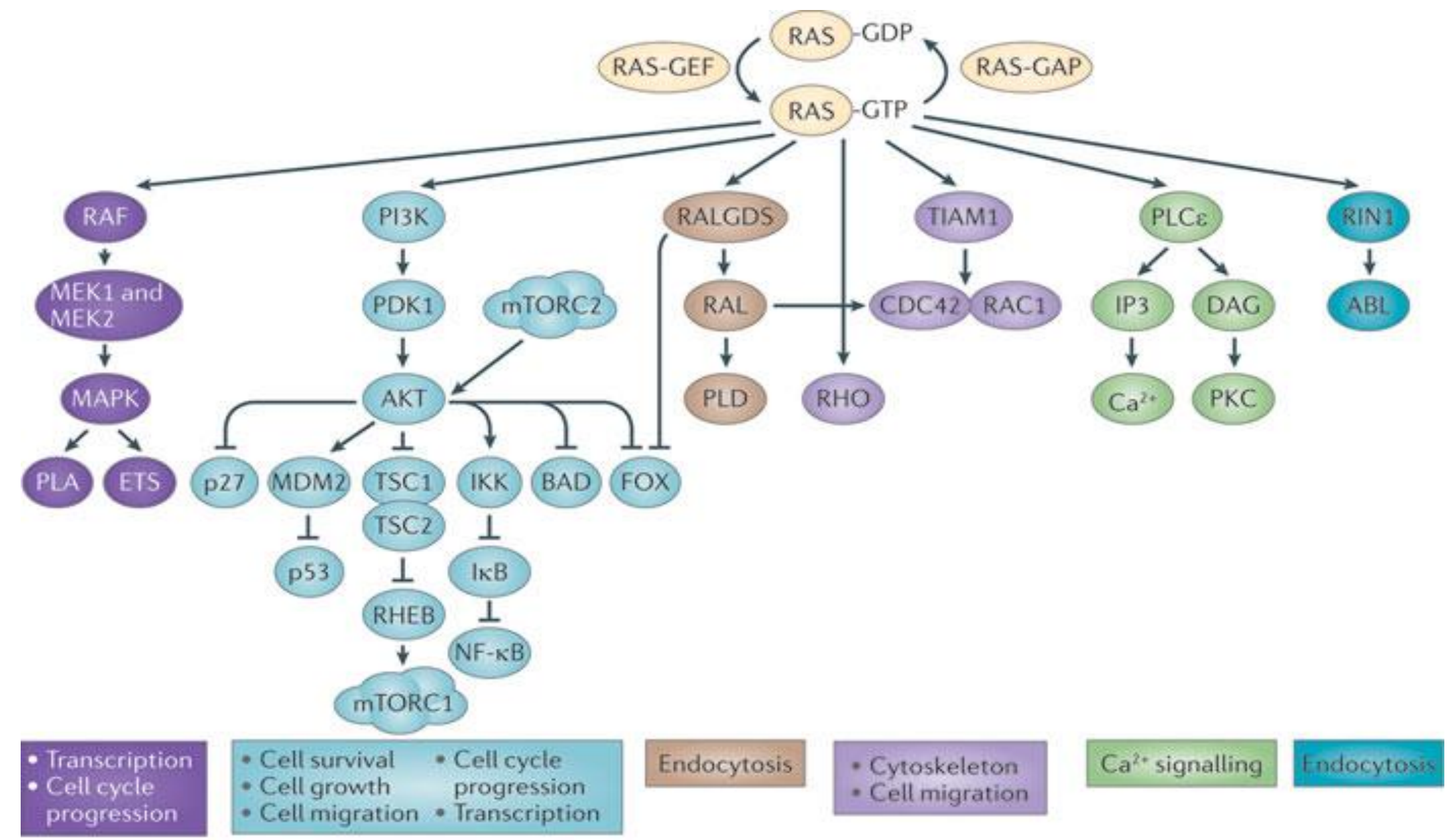

Nature Reviews | Cancer

Figura 3. Vias de sinalização reguladas pela proteína RAS. A proteína RAS, quando ativada, participa em diversas cascatas de sinalização essenciais para o desenvolvimento e homeostase celular (BERNDT; HAMILTON; SEBTI, 2011). 
As proteínas RAS residem livremente no citosol quando inativas e recebem modificações específicas pós-traducionais para suas ativações (RAJASEKHARAN; RAMAN, 2013; VETTER; WITTINGHOFER, 2007). Primeiramente dois tipos de enzima, a farnesiltranferase (FTase) que catalisa a transferência para a proteína RAS de um isoprenóidefarnesil (um grupo composto por 15 Carbonos) ou a geraniltransferase tipo I (GGTase - I), enzima que catalisa a transferência para a proteína RAS de um isoprenóidegeranil (constituído por um grupo de 20 carbonos). Ambos radicais hidrofóbicos são ligados ao resíduo de Cisteína da região terminal CAAX (C representa o aminoácido Cisteína, $A$ traduz em qualquer aminoácido alifático e $X$ qualquer aminoácido) da proteína RAS, promovendo um aumento de sua hidrofobicidade (CARR et al., 2016, SANTIAGO-TIRADO; DOERINGT, 2016). Após isso o complexo proteína - CAAX isoprenóide se liga a superfície do Retículo Endoplasmático (RE). O Resíduo AAX da porção terminal é clivado do complexo pela enzima RAS - converting (Rcel) com posterior adição de um grupo metil pela enzima isoprenilcisteína metil transferase (Icmt). Por fim o complexo recebe um grupo de cadeia longa de ácido graxo, pela palmitoil transferase, para aumentar ainda mais a sua hidrofobicidade, o que auxilia e estabiliza a sua ligação com a membrana plasmática (CARR, 2016, SANTIAGO-TIRADO; DOERINGT, 2016). Se a prenilação for inibida por inibidores de FTase e GGTase- I o complexo proteico com a porção terminal CAAX não se liga ao retículo endoplasmático, não sendo processado e não adquirindo as propriedades ideais para a sua associação com a membrana plasmática. Como consequência não haverá o desencadeamento da ativação da transdução de sinal mediada pela proteína RAS. (Figura 4) (SHEN et al., 2014).

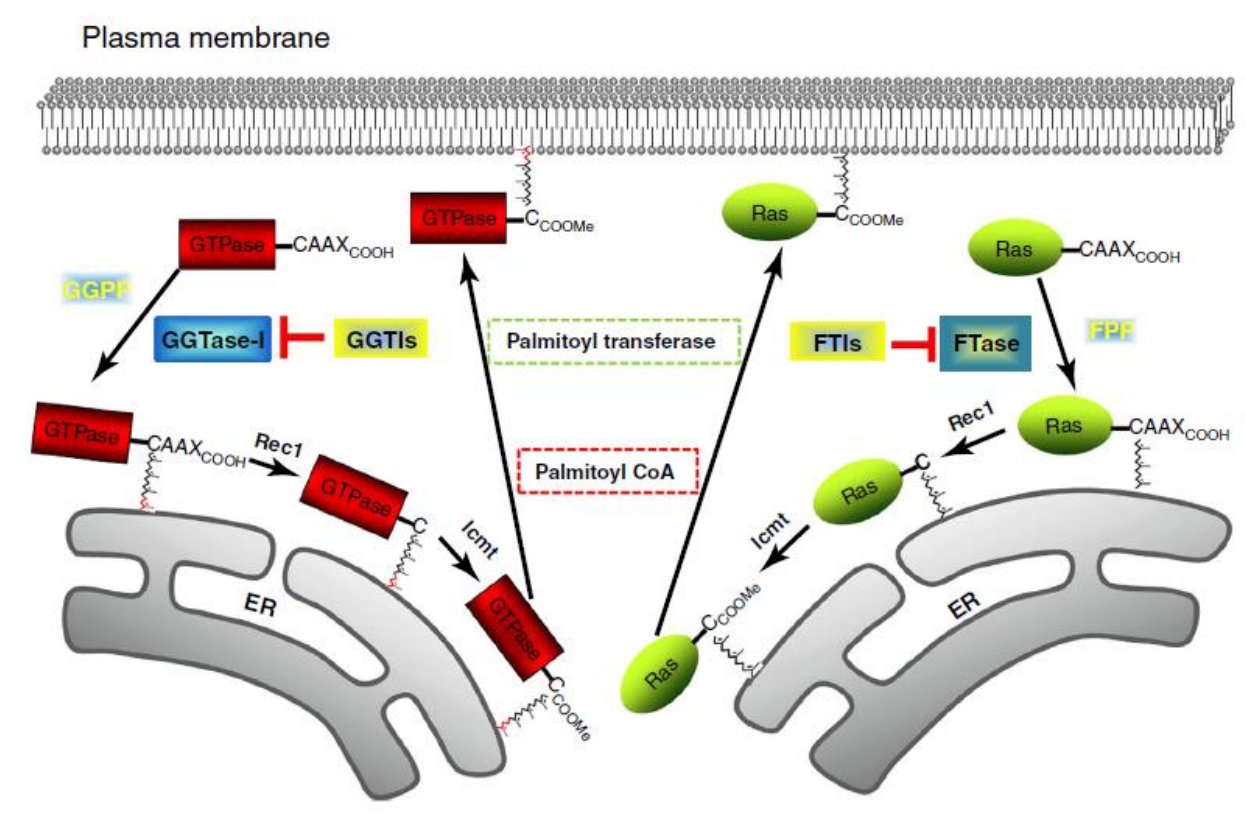

Figura 4. Processo de ativação da proteína RAS. A figura representa o processo de ativação da RAS pelas enzimas farnesiltranferase (FTase) ou a geraniltransferase tipo I (GGTase - I). Diversas etapas são requeridas para o aumento da hidrofobicidade da proteína, como prenilação, proteólise e metilação. Tais etapas possibilitam a interação proteína - membrana plasmática promovendo sua ativação e desencadeando os processos de transdução de sinal (SHEN et al., 2014, CARR, 2016). 
Quase todos os tipos de cânceres pancreáticos e grande parte das lesões precursoras são decorrentes de mutações no códon 12 do oncogene K-RAS (Tabela 2) (VASAN; BOYER; HERBST, 2014, SANTARPIA, 2017). Esta mutação é reconhecida como o evento mais precoce da tumorigênense do câncer pancreático (RAJASEKHARAN; RAMAN, 2013, SANTARPIA, 2017). A proteína K-RAS tem um papel chave na regulação de muitos eventos celulares, incluindo a proliferação celular. Essa ativação é um evento GTP-dependente e finalizado pela hidrólise do GTP com formação de GDP (VETTER; WITTINGHOFER, 2001, SANTARPIA, 2017).

Tabela 2. Prevalência dos diferentes tipos de mutação da proteína RAS nos órgãos. $O$ gráfico mostra a porcentagem dos cânceres com as mutações de RAS (KRAS, HRAS e NRAS), em diferentes tipos de órgãos (Adaptado de VASAN; BOYER; HERBST, 2014).

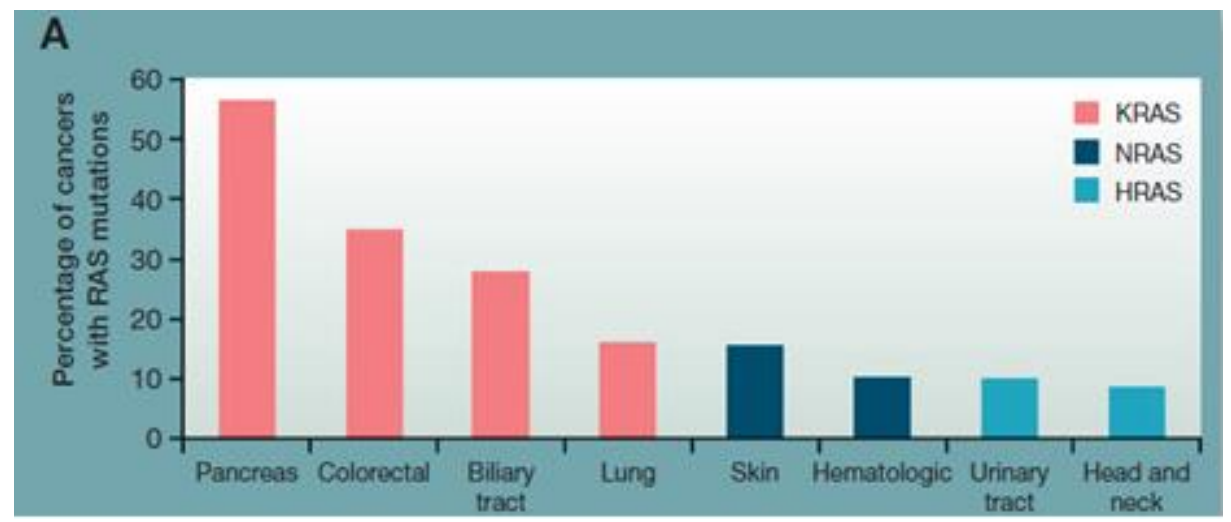

No estado normal da proteína RAS sua ativação é mediada pelo fator de troca de nucleotídeos de guanina (GEF) substituindo o GDP associado à aproteína RAS pelo GTP. Para inativação da proteína RAS, as proteínas ativadoras de GTPase catalisam a hidrólise do GTP para GDP. A mutação oncogênica principal da proteína K-RAS interfere no evento terminal e, como resultado, a proteína é mantida permanentemente ativada e um sinal contínuo de indução de proliferação é transmitido ao núcleo destas células, (Figura 5) mediados por KRAS, HRAS e NRAS, em diferentes tipos de órgãos (VASAN; BOYER; HERBST, 2014; RAJASEKHARAN; RAMAN, 2013; VETTER; WITTINGHOFER, 2007). A ativação oncogênica da K-RAS pode ocorrer em cerca de $97 \%$ das neoplasias pancreáticas (COX et al., 2014). Por estas razões as proteínas da família RAS são consideradas alvos promissores para produção de moléculas inibitórias de sua atividade (SANTARPIA, 2017, NAGY et al., 2016). Além do câncer de pâncreas, diversos outros cânceres humanos ocorrem em decorrência de mutações diretamente nas proteínas RAS ou suas derivadas RAS-Driven (RAJASEKHARAN; RAMAN, 2013, NAGY et al., 2016). Estas doenças atualmente são de difícil tratamento, sendo ainda excluídas de tratamentos com terapias alvo-específicas (RAJASEKHARAN; RAMAN, 2013, NAGY et al., 2016). 


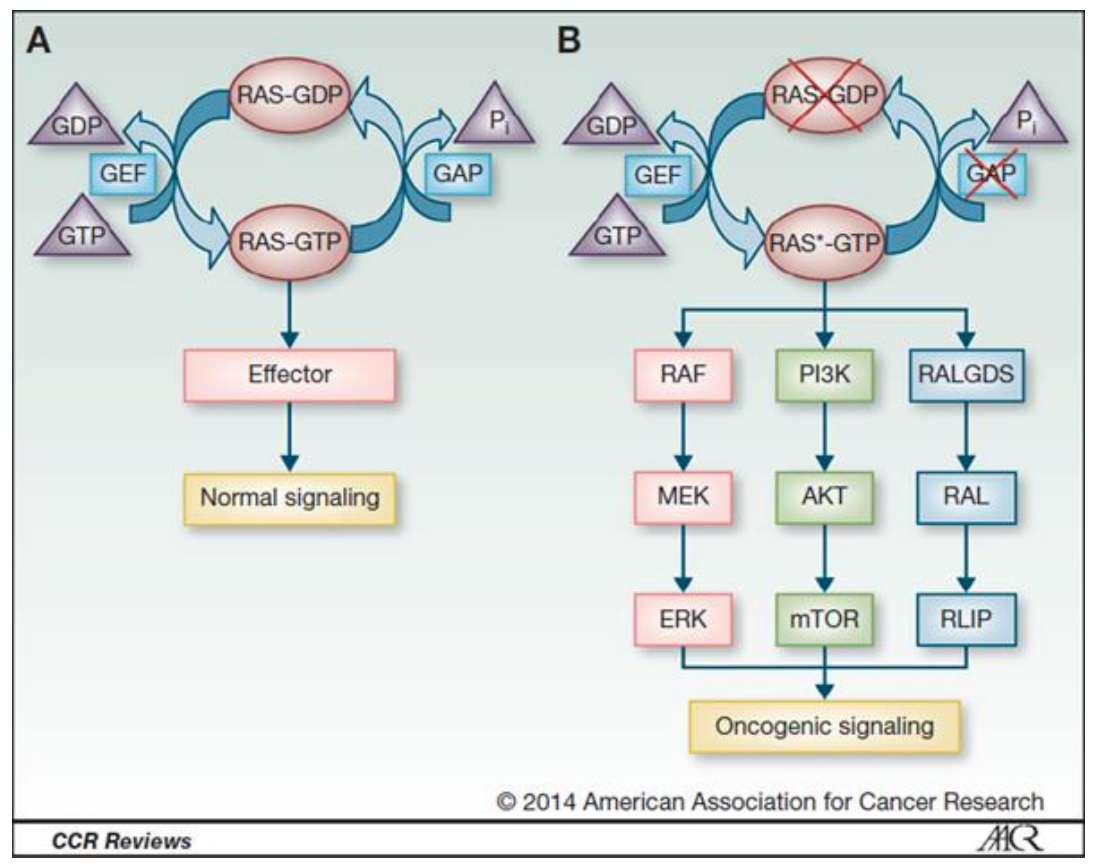

Figura 5. Comparação entre a cascata de sinalização da proteína RAS normal e a mutada. A. Processo de ativação da RAS regulada por GAP e GEF, desencadeando cascata de sinalização normal. B. Na presença da RAS mutada, sua ativação é constante inibindo a capacidade de regulação por GAP, o que promove a sinalização contínua das vias metabólicas nas quais a RAS participa (KRAS, HRAS e NRAS), em diferentes tipos de órgãos (Adaptado de VASAN; BOYER; HERBST, 2014).

\section{As quinolonas}

As quinolonas são moléculas derivadas das quinolinas, substância essa obtida pela destilação alcalina da quinina. Este composto foi primeiramente isolado da casca de Chinchona em 1811, o que gerou um impulso na descoberta de outros derivados de quinina obtidos de fontes naturais (HEEB, S. et al 2011). Posteriormente, foi possível identificar e isolar derivados de quinolonas em animais, plantas e microorganismos, o que gerou a caracterização de diferentes atividades terapêuticas como antialérgica e antimicrobiana. Considerando sua alta potencialidade, amplo espectro de atividade, boa biodisponibilidade e vasto volume de distribuição sistêmica, somado a brandos efeitos adversos, as quinolonas são moléculas promissoras para aplicação terapêutica humana e veterinária (ANDERSSON; MACGOWAN, 2003, LAKHANI et al.,2017, KOCSIS; DOMOKOS; SZABO, 2016).

O primeiro derivado de quinolona produzido foi o ácido nalidíxico, porém foram gastos mais de dez anos entre sintese, testes e formulações para que outros derivados se tornassem viáveis para liberação do seu uso medicinal, como os derivados flumequinina, norfloxacina e enoxacina (a formulação foi focada para a principal função de tratamento que foi na infecção urinaria) (ANDERSSON; MACGOWAN, 2003, KOCSIS; DOMOKOS; SZABO, 2016). Com base nesta linha de raciocínio, diversos derivados de quinolonas foram sintetizados visando atender 
demandas específicas de determinadas doença através de modificações pontuais em suas estruturas moleculares (ANDERSSON; MACGOWAN, 2003, KOCSIS; DOMOKOS; SZABO, 2016). No total, quatro gerações foram produzidas desses derivados, com características especificas em cada uma delas, considerando o ácido nalidíxico como precursor em todas elas, sendo conhecidas comumente como fluoroquinolonas (LAKHANI et al.,2017, KOCSIS; DOMOKOS; SZABO, 2016). Os derivados das primeiras gerações, atualmente, não são mais utilizados por não possuírem uma atividade tão efetiva e de amplo espectro como os das gerações posteriores e por alguns apresentarem potencial cancerígeno, como foi determinado para o ácido nalidíxico em 1998 (OEHHA, 2017). Alguns outros compostos das gerações mais recentes foram retirados do uso medicinal por apresentarem atividade citotóxica não seletiva, o que impacta negativamente na indução de efeitos adversos, o que impões que novos testes mais rigorosos devam ser aplicados aos demais derivados que estão em uso no mercado (BALL, 2000).

A atividade antimicrobiana dos derivados de quinolonas consiste basicamente na inibição da replicação do DNA bacteriano, em bactérias gram-negativas suscetíveis. As quinolonas inibem seletivamente o domínio de ligação das enzimas topoisomerase IV e DNA girase, pertencentes à família das topoisomerases tipo II (QANDIL et al., 2017, ALDRED; KEMS; OSHEROFF, 2014). Durante a replicação do DNA, ocorre o deslocamento da forquilha de replicação na fita dupla de DNA, esta abertura da fita induz a formação do superenovelamento das fitas a frente da forquilha de replicação, o que resulta no comprometimento do processo normal de duplicação do DNA por impedimento físico devido a tensão nas fitas superenoveladas. As topoisomerases atuam inibindo esse superenovelamento através da clivagem reversível de uma das fitas do DNA, passagem da fita adjacente pelo espaço clivado da primeira fita e posterior religação da fita que foi clivada (ALDRED; KEMS; OSHEROFF, 2014, RODEROVA et al., 2017). A interferência com esse processo induz a formação de um complexo de clivagem que fragmenta o DNA bacteriano (HOOPER, 2001, POMMIER et al., 2010).

Recentemente, muita atenção vem sendo dedicada não a atividade antimicrobiana da classe das quinolonas, mas às suas propriedades citotóxicas. Esta classe tornou-se objeto de interesse devido sua ação sobre a topoisomerase II, mecanismo semelhante à ação de vários compostos antitumorais clinicamente importantes como o etoposide, doxorrubicina, mitoxantrona e ansacrina. Estudos realizados com a ciprofloxacina, um derivado de quinolona de segunda geração (sintetizado na década 80 ), demonstraram efeitos inibidores do crescimento de células tumorais humanas da bexiga, da próstata, da região colorretal, de células não pequenas do pulmão, de linhagens celulares de leucemia humana e de células do osteossarcoma (GURTOWSKA; KLOSKOWSKI; DREWA, 2010, KHAN et al., 2016, SUN et al., 2013). A ciprofloxacina em altas concentrações inibe a atividade da topoisomerase II, o que não ocorre quando administrada em baixas concentrações. Mesmo assim, são capazes de reduzir a proliferação celular, estabelecendo uma atividade citostática (HALFTER et al., 2015). Foi proposto que mecanismos adicionais responsáveis pela ação citotóxica da ciprofloxacina, podem estar relacionados com sua ação na membrana celular e nas mitocôndrias (HOLTOM et al.,2000, SUN, 2013). 


\section{2. - JUSTIFICATIVA}

Apesar dos avanços na terapêutica e nas técnicas de diagnóstico, o câncer de pâncreas persiste como um grande desafio. Quando a doença é identificada precocemente, a cura pode ser alcançada com emprego combinado de diferentes modalidades terapêuticas. Entretanto, nas situações nas quais a doença esteja disseminada, o que representa a maioria dos casos, o prognóstico é invariavelmente pobre, tornando os métodos de tratamento apenas paliativos e não curativos.

Dessa forma, há uma necessidade urgente de busca por novos compostos cuja atividade possa trazer melhores resultados para o tratamento do câncer no pâncreas, visando melhorar a qualidade de vida e principalmente ampliar a expectativa de vida destes pacientes. Assim, neste trabalho se buscou avaliar in vitro o potencial de derivados de quinolonas na inibição da atividade de proteínas RAS, em conformidade com dados computacionais anteriores a síntese. Esta abordagem poderá abrir um novo caminho para o desenvolvimento de drogas para serem aplicadas no tratamento do câncer no pâncreas, tanto como fármaco principal como adjuvante.

Este projeto se ampara em extensa colaboração com grupo do Dr. Brenno A. da Silveira Neto, o qual foi o responsável pelo design, síntese e purificação dos derivados de quinolonas. As análises in vitro aqui realizadas são extremamente relevantes e essenciais, pois tais parâmetros são empregados para auxiliar no entendimento dos mecanismos pelos quais os derivados das quinolonas interagem e interferem com a fisiologia das células tumorais assim como os seus efeitos em células normais. Os dados aqui gerados servirão não apenas como suporte a prospecção de atividade antitumoral, aplicada ao câncer de pâncreas, mas também serão avaliados de forma a orientar o design para a síntese de uma segunda geração destes derivados que será produzida e avaliada em breve pelo nosso grupo.

\section{3. - OBJETIVOS}

\section{1 - Objetivos gerais}

Avaliar in vitro, no modelo câncer de pâncreas humano, a atividade de inibição da proteína RAS mediada por derivados das quinolonas.

\section{2 - Objetivos específicos}

a) Determinar in vitro o perfil de citotoxicidade dos derivados de quinolonas sobre células normais e tumorais;

b) Avaliar de forma indireta a inibição da atividade da proteína RAS em células do carcinoma (PANC - 1) e adenocarcinoma (CAPAN - 2) pancreático humano;

c) Avaliar in vitro o perfil de morte celular, a proliferação celular e potencial de migração 
celular em linhagens celulares do carcinoma e adenocarcinoma pancreático humano, tratadas com os derivados da quinolona.

\section{4. - MATERIAIS E MÉTODOS}

\section{1 - Equipamentos e reagentes}

Os nove compostos utilizados neste trabalho foram sintetizados e cedidos pelo Laboratório de Química Medicinal e Tecnológica da Universidade de Brasília (UnB), coordenado pelo Prof. Brenno Amaro da Silveira Neto.

Para o cultivo celular, foram utilizados os meios de cultura Dulbecco's Modified Eagle's Medium (DMEM) e McCoy's 5A Medium (McCoy's), Soro Fetal Bovino (SFB) da empresa Gibco - Life Technologies (Carlsbad, CA, EUA), Tripsina 0,25\% em EDTA (T4049) e antibiótico Penicilina - Estreptomicina (P4333), esses últimos obtidos da empresa Sigma - Aldrich (St. Louis, Mo, EUA). Nas estimulações os compostos utilizados foram Rapamicina (R8781), 3 Metiladenina (M9281), adquiridos da Sigma - Aldrich (St. Louis, Mo, EUA). O marcador fluorescente utilizado foi Laranja de Acridina (AO) (6130), da empresa ImmunoChemistry Technologies, LLC (Bloomington, MN, EUA).

Alguns kits foram utilizados para análise de morte celular, Anexina-V conjugada a FITC (BMS500FI), da eBioscience (San Diego, CA, EUA), lodeto de Propídeo (P3566) e MTT (brometo de 3-[4,5-dimetil-tiazol-2-il]-2,5-difeniltetrazólio) da Molecular Probes - Life Technologies (Carlsbad, CA, EUA). OCellTrace ${ }^{\mathrm{TM}}$ CFSE CellProliferation Kit (C34554), da Invitrogen - Life Technologies (Carlsbad, CA, EUA) e Colchicina da Sigma-Aldrich, St.Louis, MO, EUA foram utilizados para análise de proliferação.O DMSO, da Sigma-Aldrich, St. Louis, MO, EUA foi utilizado em mais de um tipo de análise.

$\mathrm{Na}$ análise da morfologia celular o Microscópio de luz Axiovert foi utilizado e as imagens capturadas com o auxílio do software AxioVision100 - ambos da Zeiss, Alemanha.

O equipamento Spectramax M5 e o programa SoftMax Pro 5.2, ambos da Molecular Devices, LLC, EUA foram utilizados para leitura de absorbâncias e análise de dados, respectivamente. O citômetro de fluxo utilizado foi FACTTalibur, BD Biosciences, Inc., San Jose, CA e a análise dos dados realizada no programa FlowJo v.8.2.7 e vX.0.7), Tree Star, Inc. Os dados estatísticos e gráficos foram analisados e feitos no programa GraphPadPrism 5, GraphPad Software, Inc.

A análise morfológica celular foi feita através do Microscópio de luz Axiovert e as imagens capturadas com o auxílio do software AxioVision 100, Zeiss, Alemanha.

\section{2 - Síntese dos derivados das quinolonas}

Com o objetivo da produção de compostos para os testes necessários para avaliação indireta da atividade inibitória da proteína RAS a metodologia de reações multicomponentes (MCRs) foi utilizada no âmbito de maior aproveitamento dos reagentes precursores convertidos em um único produto. Essa metodologia consegue minimizar os problemas causados pela 
reação linear de síntese já que a mesma passa por um processo intermediário de purificação o que demanda a utilizando grande quantidade de solvente, gerando uma produção considerável de resíduos (ALVIM, 2013). Além disso, como na síntese linear o rendimento entre as etapas é incerto, o tempo para a obtenção do produto final pode ser demasiadamente extendido em virtude de rendimentos intermediários baixos.

Os nove compostos utilizados nesse trabalho com suas estruturas molecular e massa molar estão representados na Tabela 3.

Tabela 3. Compostos utilizados no presente trabalho com suas respectivas Fórmulas Estruturais, Fórmulas Moleculares e Massas Molares.

\begin{tabular}{|c|c|}
\hline № & Massa molar \\
\hline Quinol 1 & $241 \mathrm{~g} \cdot \mathrm{mol}^{-1}$ \\
\hline Quinol 2 & $308 \mathrm{~g} \cdot \mathrm{mol}^{-1}$ \\
\hline Quinol 3 & $360.46 \mathrm{~g} \cdot \mathrm{mol}^{-1}$ \\
\hline Quinol 4 & $273.29 \mathrm{~g} \cdot \mathrm{mol}^{-1}$ \\
\hline Quinol 5 & $299 \mathrm{~g} \cdot \mathrm{mol}^{-1}$ \\
\hline Quinol 6 & $480 \mathrm{~g} \cdot \mathrm{mol}^{-1}$ \\
\hline Quinol 7 & $403.50 \mathrm{~g} \cdot \mathrm{mol}^{-1}$ \\
\hline Quinol 8 & $284.36 \mathrm{~g} \cdot \mathrm{mol}^{-1}$ \\
\hline Quinol 9 & $256.30 \mathrm{~g} \cdot \mathrm{mol}^{-1}$ \\
\hline
\end{tabular}




\section{3 - Manutenção das linhagens celulares}

As linhagens celulares de adenocarcinoma CAPAN - 2 e carcinoma PANC - 1 foram adquiridas pelo Banco de Células do Rio de Janeiro (BCRJ) e cultivadas em meio McCoy's 5A Medium (McCoy's) e Dulbecco's Modified Eagle's Medium (DMEM), respectivamente, suplementados com $10 \%$ soro fetal bovino (SFB) e tratadas com antibiótico (100.000 U/L de penicilina e $100 \mathrm{mg} / \mathrm{L}$ de estreptomicina) em atmosfera contendo $5 \%$ de $\mathrm{CO}_{2}$ a3 $3{ }^{\circ} \mathrm{C}$.

Cada linhagem foi selecionada de acordo com a porcentagem de mutação na proteína KRAS fornecida pela Cancer Cell Line Encyclopedia (CCLE, 2016) e por representar os dois tipos mais frequentes em neoplasias pancreáticas, o adenocarcinoma, presente em mais de 90\% dos casos de câncer de pâncreas, e o carcinoma, ambos da região exócrina do pâncreas (INCA, 2016). A quantidade de células utilizadas foi dependente da especificidade de cada experimento.

\section{4 - Desenho experimental de testes dos derivados das quinolonas}

Nove compostos derivados das quinolonas, com possível atividade de inibição da proteína KRAS, foram solubilizados em DMSO para os estudos in vitro. Concentrações testadas variaram de $10 \mathrm{nmol}$ a $1 \mathrm{mmol}$ com tratamentos utilizados em tempos de 24 , 48 e $72 \mathrm{~h}$. O controle negativo, células não tratadas, foi feito apenas utilizando meio suplementado.

\section{5 - Ensaio da viabilidade celular}

A viabilidade das células tratadas com os compostos derivados das quinolonas foi determinada pelo ensaio padrão por brometo de 3-(4,5-dimetiltiazol-2-il) -2,5- difeniltetrazolium (MTT), segundo as recomendações do fabricante. As células CAPAN - 2 e PANC - 1 foram incubadas por 12 horas a $37^{\circ} \mathrm{C}$ em placas de 96 poços. Após a adesão, as células foram tratadas com concentrações de $10 \mathrm{nM}$ a $1 \mathrm{mM}$ dos derivados de quinolonas ou seus respectivos controles. Com o término do período de tratamento $(24,48$ e $72 \mathrm{~h})$, os poços foram incubados por $4 \mathrm{~h}$, com $150 \mu \mathrm{L}$ da solução de MTT $\left(0,5 \mathrm{mg} / \mathrm{mL}\right.$ em meio de cultura) no escuro a $37^{\circ} \mathrm{C}$, com posterior retirada da solução, $200 \mu \mathrm{L}$ de DMSO foram adicionados em cada poço para a dissolução dos cristais de formazan. Para a obtenção dos dados experimentais as placas foram lidas no espectrofotômetro Spectramax M5 (Molecular Devices - USA). O ensaio de MTT foi feito em triplicata para cada composto e cada concentração em três experimentos independentes. Comparando a densidade das células tratadas com as células controle nos tempos respectivos de incubação foi possível determinar a porcentagem de inibição [porcentagem de inibição $=(1-$ densidade das células do grupo tratado $) /$ densidade das células do grupo controle]. 


\section{6 - Determinação do IC 50}

O IC 50 , concentração que inibe $50 \%$ da viabilidade celular é calculada baseada na porcentagem de células viáveis contra a dose de tratamento em escala logarítmica.

\section{7 - Análise de proliferação celular}

Para análise de proliferação celular o Carboxyfluorescein Diacetate Succinimidyl Ester (CFSE) é um marcador utilizado, por não ser citotóxico e ser incorporado pelas células (com sua clivagem, torna-se fluorescente). Após as divisões celulares, parte do marcador é repassado para as novas células fazendo com que a intensidade da fluorescência diminua pela metade em cada ciclo de divisão celular.

$2 \times 10^{5}$ células foram incubadas por 12 horas a $37^{\circ} \mathrm{C}$ em placas de 24 poços contendo $400 \mu \mathrm{L}$ de meio de cultura por poço. Após adesão as células foram tratadas de acordo com a determinação do $\mathrm{IC}_{50}$ no período de $24 \mathrm{~h}$ ou em meio de cultivo para as células controle. Para controle positivo das células com inibição de proliferação, foi utilizado o tratamento com Colchicina $(10 \mu \mathrm{M})$ por um período de $1 \mathrm{~h}$. Posteriormente aos tratamentos as células foram lavadas três vezes com PBS e o CFSE foi adicionado durante 15 minutos a $37^{\circ} \mathrm{C}$ na concentração de $10 \mu \mathrm{M}$ final (diluído em PBS/BSA 0,1\%), abrigado da luz. As células foram novamente lavadas e os meios específicos de cada linhagem foram adicionados por 30 minutos. As células foram ressuspendidas em $500 \mu \mathrm{L}$ PBS para a análise por citometria de fluxo.

Nesta análise 10.000 eventos foram obtidos com a fluorescência no canal FL1-H em escala logarítmica, e a quantificação proliferativa celular foi feita no software FlowJo de acordo com os parâmetros de proliferação recomendados neste mesmo software.

\section{8 - Caracterização da morte celular induzida pelos derivados das quinolonas}

A análise de viabilidade celular foi obtida pela marcação das linhagens celulares com Anexina - V FITC e lodeto de Propídio (PI). Este teste permite a identificação e quantificação das células viáveis, em estagio de apoptose inicial (quando a fosfatidilserina é marcada pela Anexina-V, por conta da perda da assimetria dos componentes da membrana), apoptose tardia e necrose (células que perdem a integridade da membrana permitem a passagem do PI pela membrana celular).

$2 \times 10^{5}$ células foram incubadas por 12 horas a $37^{\circ} \mathrm{C}$ em placas de 24 poços contendo $400 \mu \mathrm{L}$ de meio de cultura por poço. Após adesão as células foram tratadas de acordo com a determinação do $\mathrm{IC}_{50}$ no período de $24 \mathrm{~h}$ ou em meio de cultivo para as células controle. Como controle positivo experimental, foi induzido a apoptose em uma amostra celular tratadas com $20 \%$ de DMSO por 15 minutos em meio de cultura. Para obtenção de células necróticas uma outra amostra foi submetida ao aquecimento a $70^{\circ} \mathrm{C}$ por 15 minutos. Posteriormente ao tratamento o sobrenadante foi coletado e centrifugado com o intuito de resgate de células 
mortas desaderidas. Após isso as células foram lavadas três vezes com PBS e ressuspendidas em $100 \mu \mathrm{L}$ de Tampão de Ligação de Anexina - V 1X (HEPES 10mM; NaCl 140mM; CaCl2 $2,5 \mathrm{mM}-\mathrm{pH} 7,4)$ e incubadas com $2 \mu \mathrm{L}$ de Anexina-V FITC por 15 minutos, em temperatura ambiente, abrigado da luz. 400 $\mu \mathrm{L}$ de Tampão de Ligação de Anexina - V $1 \mathrm{X}$ e $500 \mu \mathrm{L}$ da solução de PI (PBS e lodeto de Propídio, $2 \mu \mathrm{g} / \mathrm{ml}$ de concentração final) por 5 minutos foram adicionados posteriormente a $4^{\circ} \mathrm{C}$, abrigado da luz. Por fim as células foram lavadas e ressuspendidas em $500 \mu \mathrm{L}$ de PBS para análise no citômetro de fluxo FACTTalibur (Becton Dickinson) usando o software CellQuest - Pro.

Nesta análise 10.000 eventos foram obtidos com a fluorescência no canal FL1-H e FL3$\mathrm{H}$ em escalas logarítmicas em 3 experimentos independentes realizados em monoplicata e avaliado através da porcentagem de células obtidas em cada quadrante gerado pelo gráfico específico de morte celular.

\section{9 - Análise de presença de vesículas acídicas}

A confirmação da indução de autofagia, que é um processo dependente de proteína RAS, pode ser corroborada pela presença de vesículas acídicas através da marcação com Laranja de Acridina. Esse marcador se acumula nos lisossomos das células já que possuem um pH baixo e por ser uma base fraca. Essa ligação, quando excitada por luz azul, produz uma fluorescência vermelha.

$2 \times 10^{5}$ células foram incubadas por 12 horas a $37^{\circ} \mathrm{C}$ em placas de 24 poços contendo $400 \mu \mathrm{L}$ de meio de cultura por poço. Após adesão as células foram tratadas de acordo com a determinação do $I_{50}$ no período de $24 \mathrm{~h}$ ou em meio de cultivo para as células controle. Posteriormente ao tratamento as células foram lavadas três vezes com PBS e incubadas com solução de Laranja de Acridina $1 \mu \mathrm{g} / \mathrm{mL}$, concentração final, por 15 minutos a $37^{\circ} \mathrm{C}$, abrigada da luz. As células então foram lavadas e ressuspendidas em $500 \mu \mathrm{L}$ de PBS.

Nesta análise 10.000 eventos foram obtidos com a fluorescência no canal FL1-H e FL3$\mathrm{H}$ em escalas logarítmicas. A análise dos dados foi comparada com as médias geométricas de intensidade de fluorescência das células tratadas com as células-controle.

\subsection{0 - Migração celular}

Para avaliar a migração das células de linhagem tumoral CAPAN - 2 e PANC - 1, in vitro, foi utilizado o ensaio de "wound healing" ou "cell scratch" (ZHANG et al., 2013). Este método mimetiza a migração celular durante a cicatrização de feridas in vivo. O ensaio consiste na realização de uma raspagem na superfície de uma camada de células confluentes, e avaliação do fechamento desta lesão através da migração celular. Para isso, as células foram mantidas em placas de 24 poços, nas condições padrões de cultivo de cada linhagem, até atingirem confluência de aproximadamente $90 \%$. Após este período foi realizada uma raspagem na camada de células utilizando a ponta de uma ponteira de $200 \mu \mathrm{L}$. Em seguida as células foram lavadas com meio completo e a imagem da cultura obtida por registro fotográfico através de 
uma câmera acoplada ao Microscópio de luz Axiovert na objetiva de 10X com o auxílio do software AxioVision 100, Zeiss, Alemanha. A migração foi observada em intervalos regulares de 12 horas por um período de 72 horas. As imagens obtidas comparadas e analisadas através do software FIJI (SCHINDELIN; ARGANDA-CARRERAS, 2012).

4.11- Avaliações morfológicas das células tumorais tratadas com os derivados das quinolonas

Para a avaliação de mudança morfológica, as células das linhagens tumorais CAPAN 2 e PANC - 1 foram tratadas com os quatro derivados de qinolonas em placas de 12 poços, nos periodos de tempo de 24, 48 e $72 \mathrm{~h}$, e analisadas pelo microsccópio de luz Axiovert na objetiva de $32 \mathrm{X}$ com o auxílio do software AxioVision 100, Zeiss, Alemanha.

\subsection{2 - Análises estatísticas}

Os dados foram analisados pelos testes de variância simples (ANOVA) e pós-teste Bonferroni. Os cálculos e gráficos foram reproduzidos usando o Software GraphPad Prisme v 5 . Valores de $p<0,05$ foram considerados estatisticamente significativos.

\section{5. - RESULTADOS}

\section{1 - Os derivados de quinolonas testados não apresentaram citotoxicidade significativa para células tumorais do pâncreas dose nem tempo dependentes}

Primeiramente, foram analisados os níveis de citotoxicidade dos nove derivados de quinolonas para as linhagens tumorais CAPAN - 2 e PANC - 1 através de uma triagem por ensaio de MTT nas concentrações de $10 \mathrm{nM}$ a $1 \mathrm{mM}$ nos períodos de tempo de 24, 48 e $72 \mathrm{~h}$.

Apesar de uma leve diminuição da viabilidade celular observada para algumas concentrações dos nove derivados, em ambas as linhagens tumorais testadas os resultados não foram estatisticamente significativos para citotoxicidade no tempo de 24 h (Figura 6).

Com esse resultado preliminar, foram feitas avaliações nos períodos de tempo de 48 e $72 \mathrm{~h}$ para a verificação de possível atividade citotóxica tempo dependente. Estes ensaios foram realizados apenas com os derivados que possuíam a coloração mais clara em solução (Quinol 1, Quinol 2, Quinol 3 e Quinol 4), devido a diversas dificuldades surgidas nas análises por MTT dos compostos que produziam soluções de coloração escura. (Figura 7).

O mesmo resultado negativo foi obtido com os quatro derivados mais claros para os períodos de 48 e $72 \mathrm{~h}$. Nenhum dos derivados aqui testados apresentaram atividade citotóxica estatisticamente significativa, dose e tempo dependentes, para as linhagens tumorais utilizadas CAPAN - 2 e PANC - 1. Logo, com esses resultados os quatro derivados no período de $24 \mathrm{~h}$ foram utilizados para posteriores análises com o intuito de identificar uma possível interferência nas atividades normais metabólicas das linhagens tumorais pancreáticas na concentração de $100 \mu \mathrm{M}$ (caso os derivados tenham alguma atividade antitumoral nas análises in vitro, a próxima etapa é a ánalise in vivo, concentração máxima não citotóxica utilizada nesse tipo de análise). 


\section{CAPAN - 2}

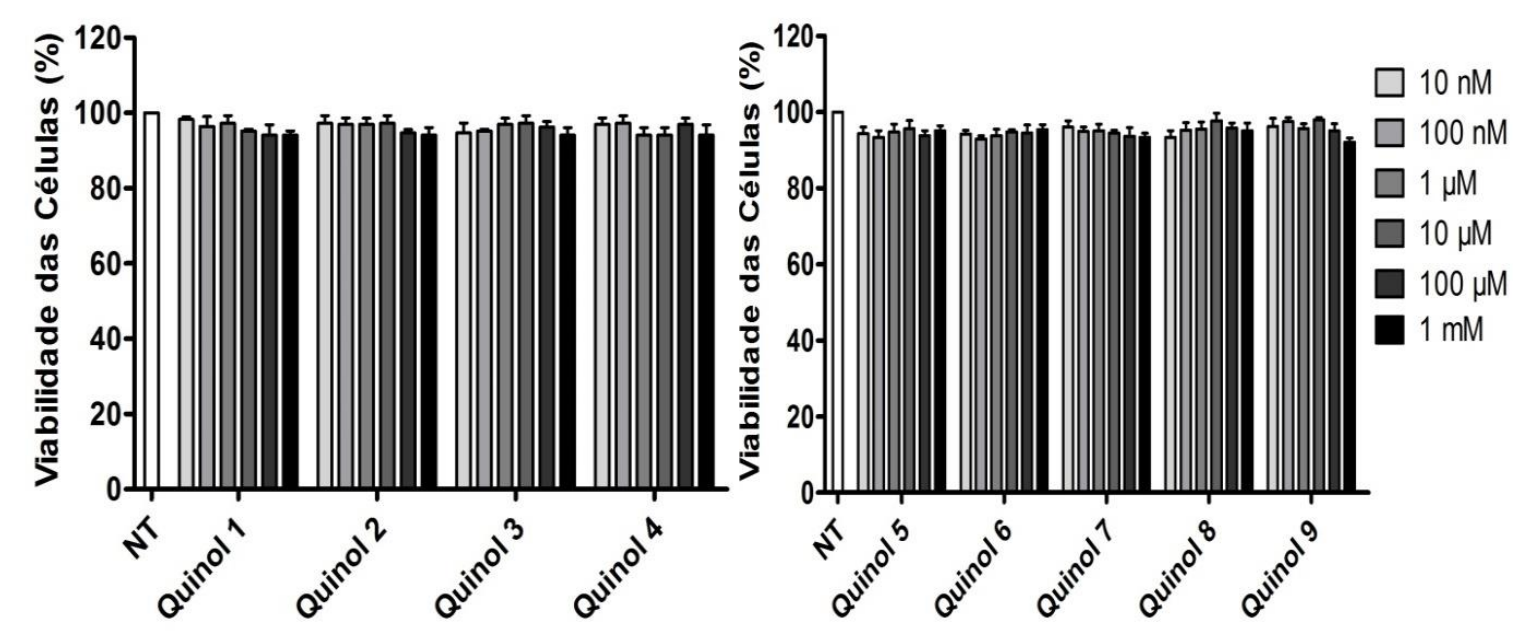

PANC - 1

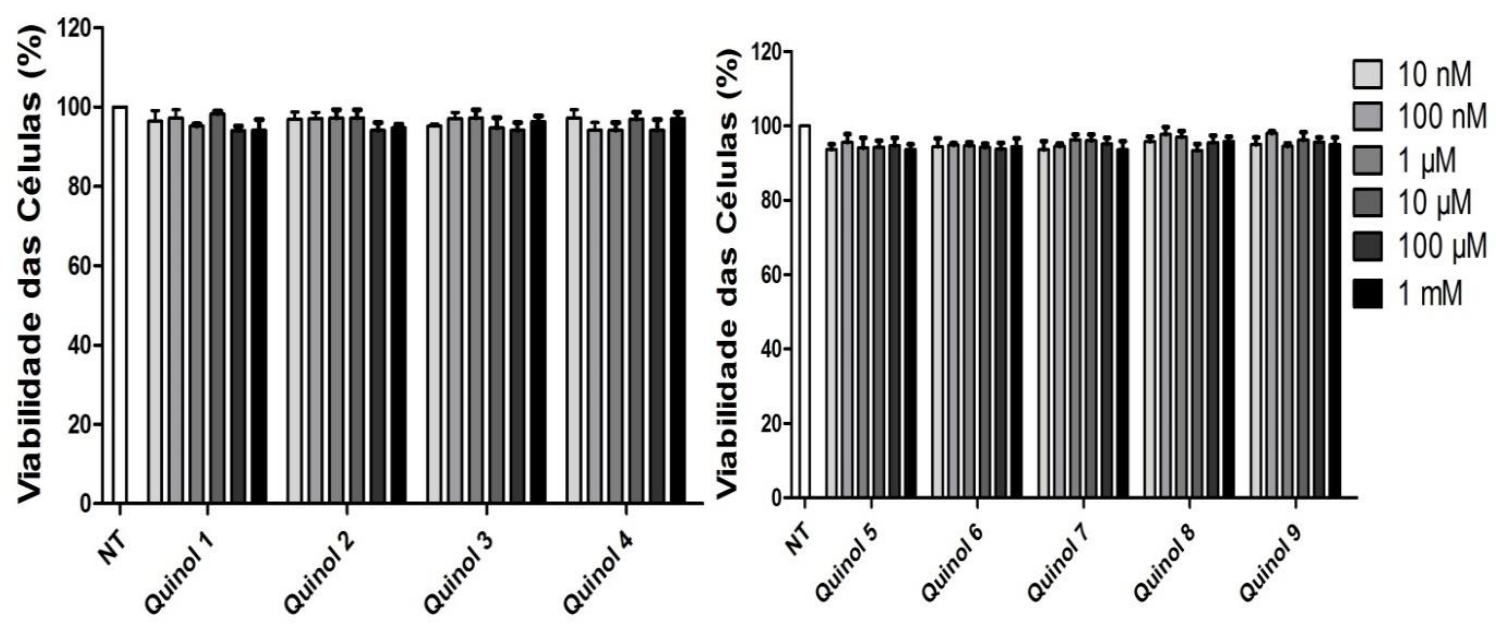

Figura 6. Viabilidade celular das linhagens tumorais CAPAN - 2 e PANC - 1 no período de tempo de 24h. Os nove derivados de quinolonas foram utilizados para o tratamento das linhagens tumorais CAPAN - 2 e PANC - 1 nas concentrações de $10 \mathrm{nM}$ a $1 \mathrm{mM}$ no período de $24 \mathrm{~h}$ e analisados por espectofotometria. Não foi observada diferença estatisticamente significativa entre o controle negativo e os tratamentos. 
CAPAN - 2

A

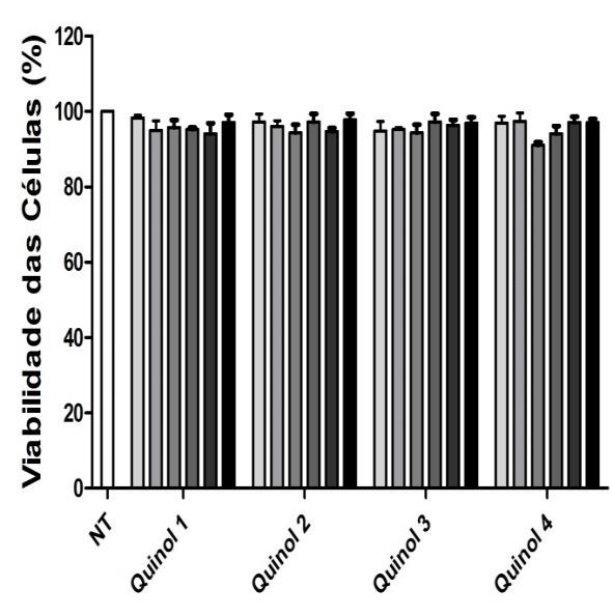

C

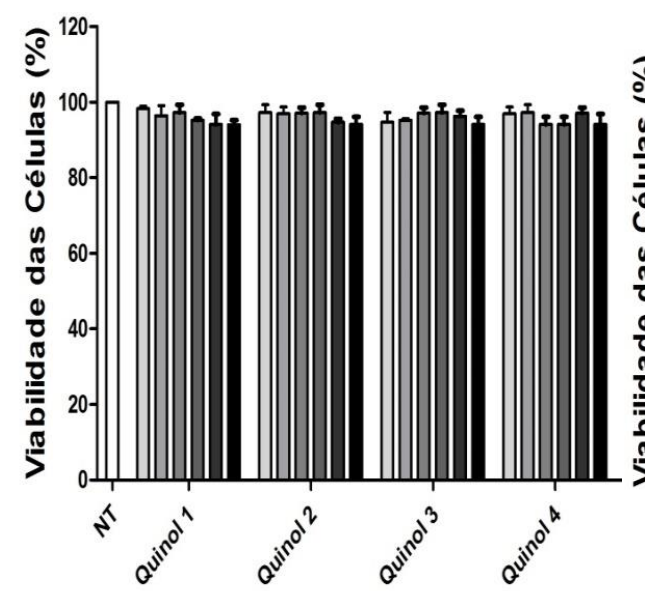

B

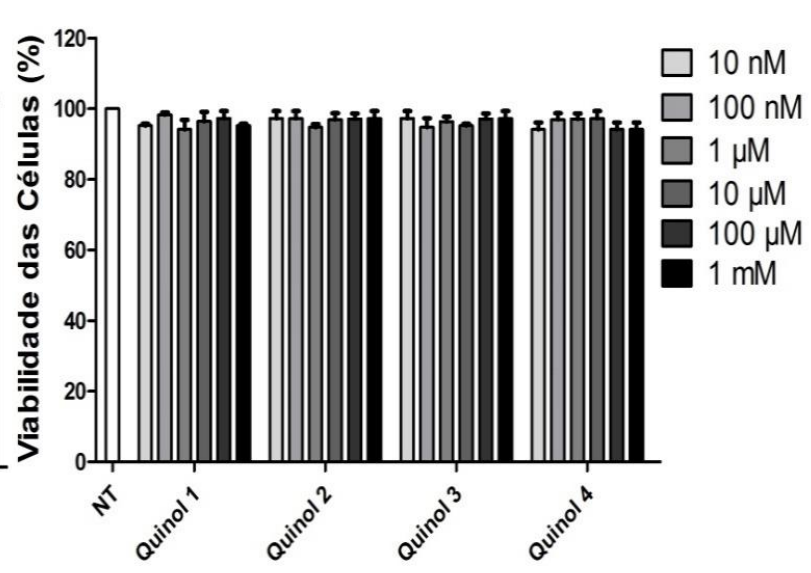

D

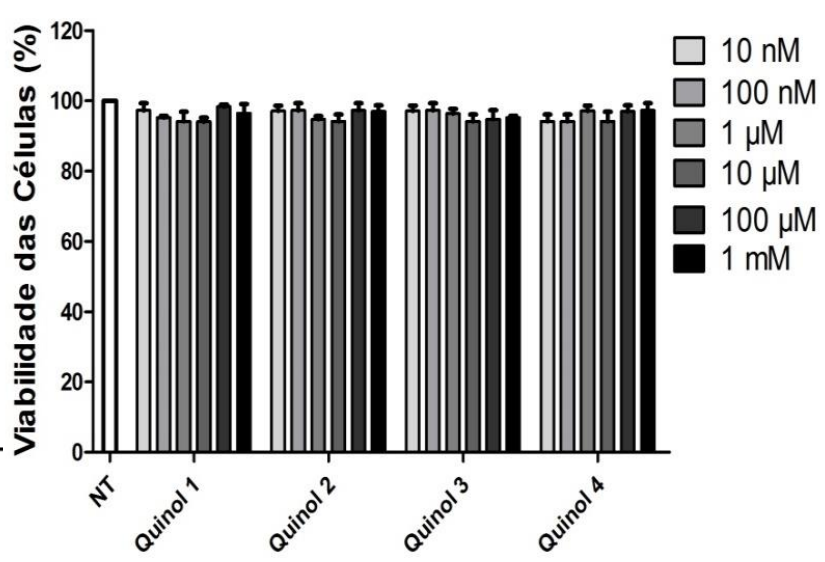

Figura 7. Viabilidade celular das linhagens tumorais CAPAN - 2 e PANC - 1 nos períodos de tempo de 48 e $72 \mathrm{~h}$. A e B. Citotoxicidade produzida por derivados de quinolona utilizados para o tratamento das linhagens tumorais CAPAN - 2 e PANC - 1, respectivamente, no intervalo de concentração de $10 \mathrm{nM}$ a $1 \mathrm{mM}$ no período de $48 \mathrm{~h}$. C e D. Citotoxicidade produzida por derivados de quinolona utilizados para o tratamento das linhagens tumorais CAPAN - 2 e PANC - 1, respectivamente, no intervalo de concentração de $10 \mathrm{nM}$ a $1 \mathrm{mM}$ no período de $72 \mathrm{~h}$ e analisados por espectofotometria. Não foi observada diferença estatisticamente significativa entre o controle negativo e os tratamentos. 


\section{2 - Os derivados de quinolonas não foram capazes de induzir a morte celular nas linhagens tumorais de pâncreas de forma significativa}

Com o intuito de avaliação da indução de morte celular pelos derivados de quinolonas nas linhagens tumorais de pâncreas, foi selecionada a concentração de $100 \mu \mathrm{M}$ para ser utilizada. Esta concentração está dentro dos critérios de aplicabilidade prática exigidos em fases posteriores de testes, como a determinação da dose máxima não citotóxica in vivo. Foi avaliada a indução de morte celular dentro do período de $24 \mathrm{~h}$, uma vez que não fora observada diferença na viabilidade celular pelo método do MTT nos tempos posteriores a 24 horas. ensaio de perfil morte celular, consistiu na marcação das amostras com os marcadores Anexina - V, e lodeto de Propideo (PI).

Do ponto de vista estatístico, foram observadas diferenças da associação das células aos marcadores o que pode ser traduzido em fase inicial e tardia da apoptose assim como também para a necrose. No entanto, todos estes indicadores apresentaram valores extremamente baixos (maioria absoluta abaixo de $1 \%$ com apenas um evento de fase tardia da apoptose alcançando 1,59\%). Sendo assim, em nossa avaliação, para ambas as linhagens tumorais de pâncreas, os quatro derivados de Quinolonas utilizados não foram capazes de induzir nem a morte celular por apoptose, nem o processo de necrose celular (Figuras 8 e 9).

Apesar disso, quando aplicado tratamento estatístico foi possível observar aumento dos níveis de apoptose das células tratadas com os quatro derivados em relação ao controle, aumento do nível de necrose das células tratadas com o derivado Quinol 2 e não indução de da necrose nas células tratadas com os derivados Quinol 1, Quinol 3 e Quinol 4. Também podemos observar aumento do nível de apoptose tardia das células tratadas com o derivado Quinol 3 e redução do número de células em de apoptose tardia nas células tratadas com os derivados Quinol 1, Quinol 2 e Quinol 4, na linhagem tumoral CAPAN - 2, figura 10. Embora o tratamento dos números gere resultados estatisticamente significativos, nós não podemos considerar estes dados como úteis para qualquer extrapolação em prol da aplicabilidade destes compostos como agentes antitumorais. (Figura 10).

Da mesma forma, o tratamento estatístico dos números gerou para a linhagem tumoral PANC - 1, o aumento dos níveis de apoptose nas células tratadas com os quatro derivados (Figura 11); assim como o aumento do nível de necrose das células tratadas com o derivado Quinol 2 e a não indução da necrose nas células tratadas com os derivados Quinol 1, Quinol 3

e Quinol 4. É possível observar ainda, através dos dados estatísticos, um aumento da quantidade de células na fase tardia da apoptose quando tratadas com os quatro derivados (Figura 11). Da mesma maneira, estes dados são embasados em valores extremamente baixos, os quais não consideramos úteis para qualquer tipo de extrapolação em prol da aplicabilidade destes compostos como agentes antitumorais. Esta avaliação serviu ainda para confirmar o resultado de não citotoxicidade destes derivados de quinolonas empregados nas linhagens tumorais de pâncreas nos testes CAPAN - 2 e PANC - 1. 


\section{CAPAN - 2}

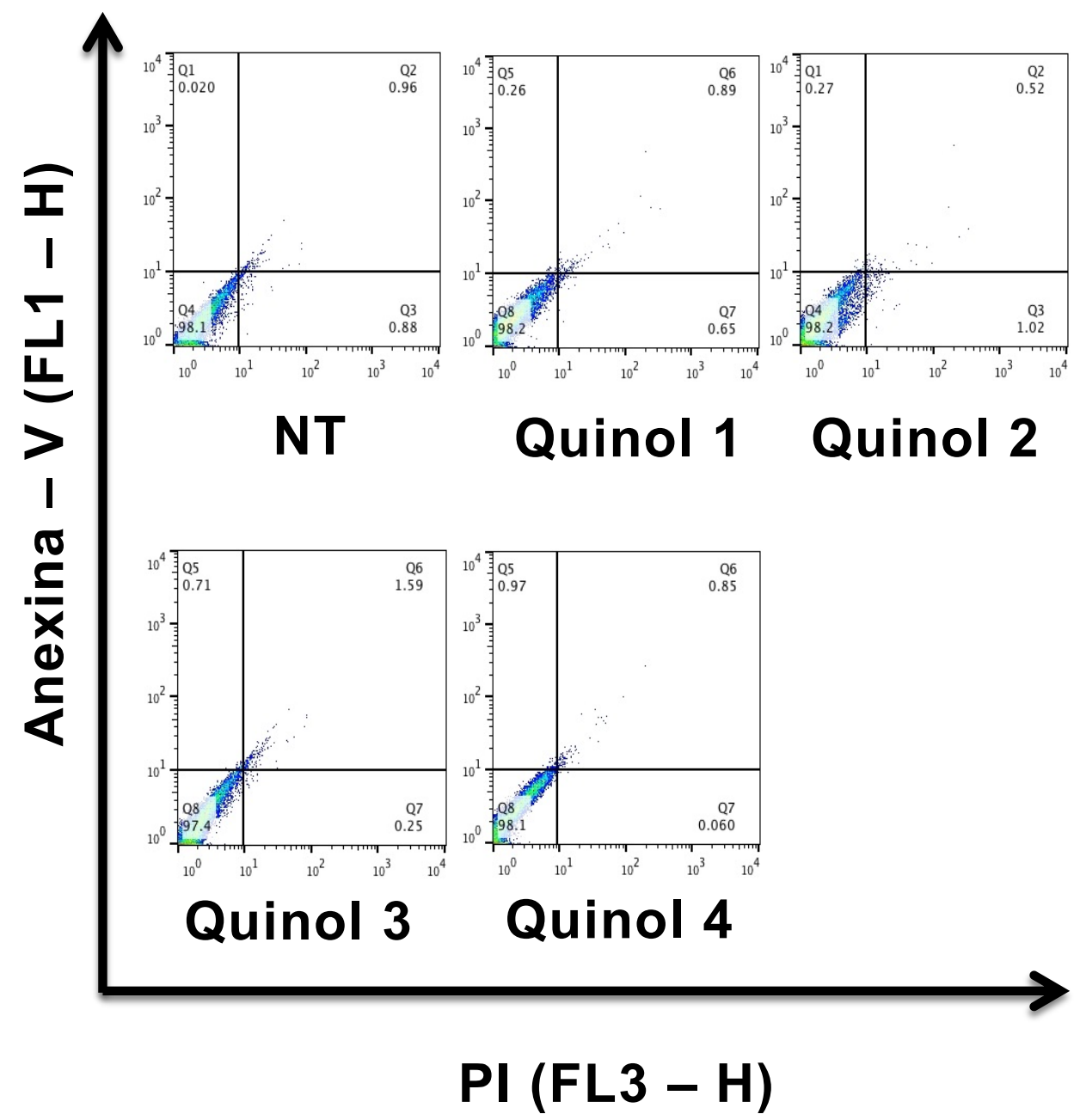

Figura 8. Avaliação do perfil de morte celular da linhagem tumoral CAPAN - 2 tratada com os derivados de quinolonas. A maioria dos pontos avaliados apresentam variações abaixo de $1 \%$. Com apenas um resultado para necrose chegando a $1,02 \%$. Amostras tratadas com os quatro derivados de quinolonas no período de tempo de $24 \mathrm{~h}$ na concentração de $100 \mu \mathrm{M}$ e analisadas por citometria. 


\section{PANC - 1}

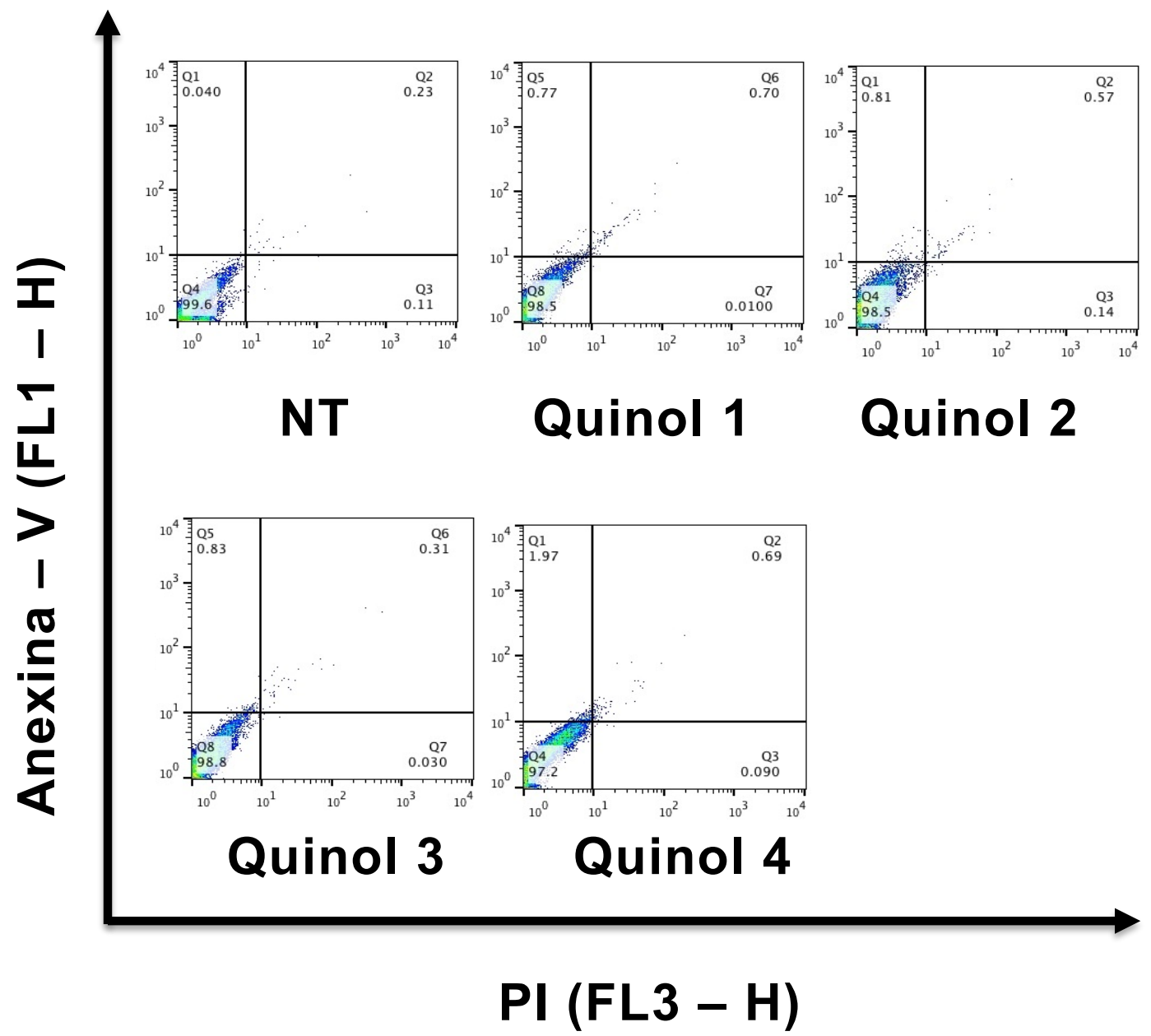

Figura 9. Avaliação do perfil de morte celular da linhagem tumoral PANC-1 tratada com os derivados de quinolonas. Todos os pontos avaliados apresentam variações abaixo de $1 \%$. Amostras tratadas com os quatro derivados de quinolonas no período de tempo de $24 \mathrm{~h}$ na concentração de $100 \mu \mathrm{M}$ e analisadas por citometria. 


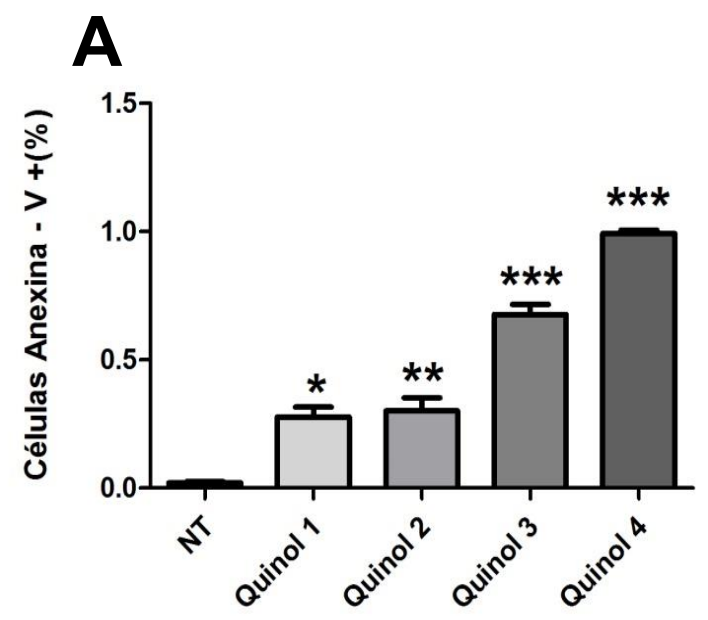

B
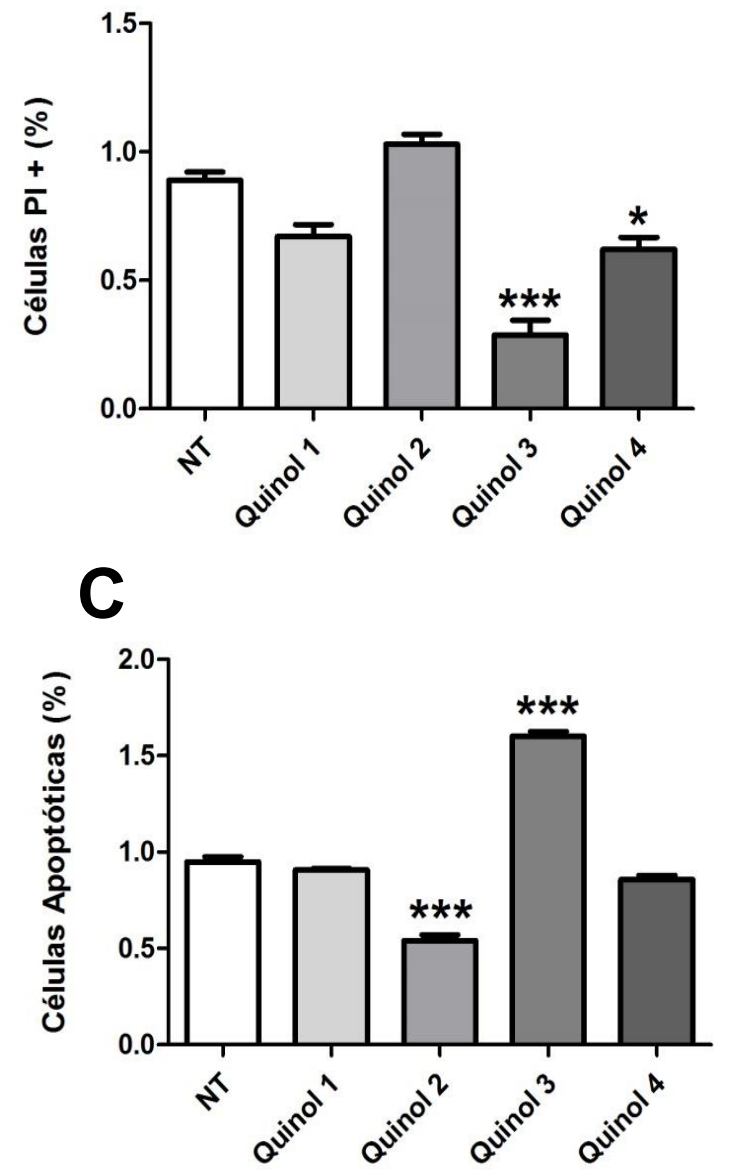

Figura 10. Morte celular da linhagem tumoral CAPAN - 2 tratada com os derivados de quinolonas. A. Porcentagem de células em fase de apoptose inicial. B. Porcentagem de células em necrose. C. Porcentagem de células em fase de apoptose tardia. As colunas representam médias e desvios padrão de três experimentos independentes. ${ }^{*} P<0.05,{ }^{* *} P<0,01$ e ${ }^{* * *} P$ $<0,001$. 

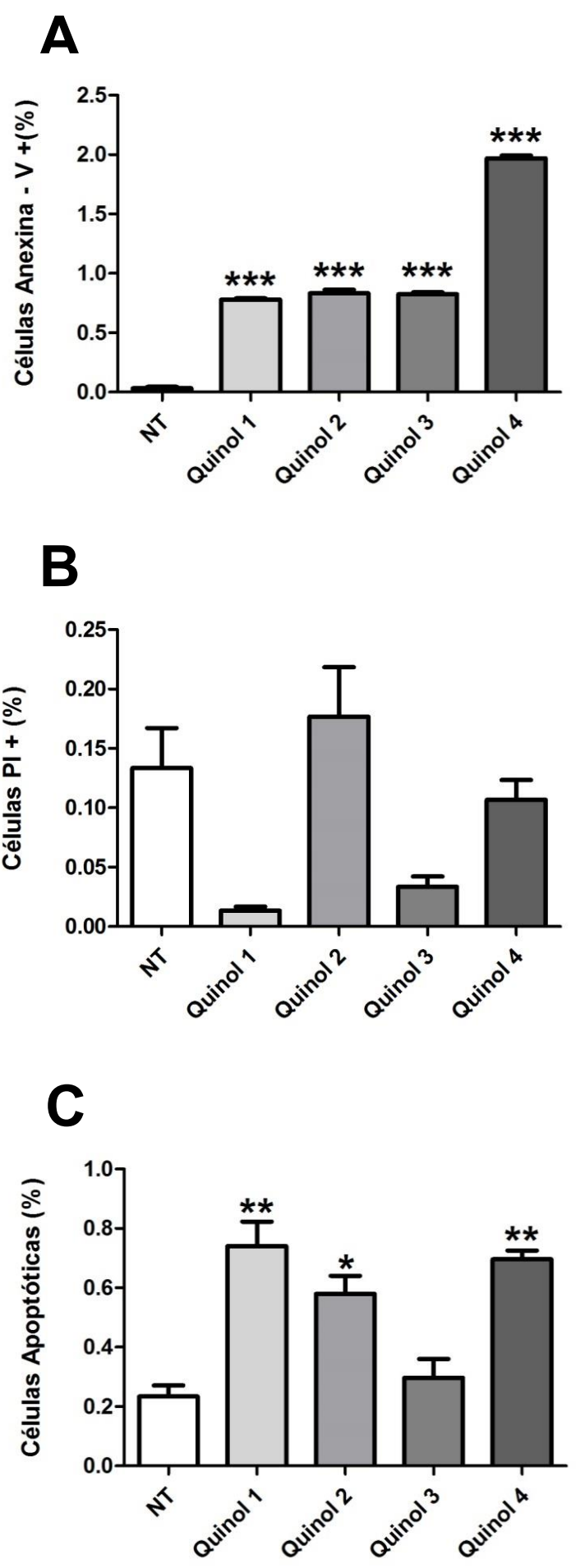

Figura 11. Morte celular da linhagem tumoral PANC - 1 tratada com os derivados de quinolonas. A. Porcentagem de células em fase de apoptose inicial. B. Porcentagem de células em necrose. C. Porcentagem de células em fase de apoptose tardia. As colunas representam médias e desvios padrão de três experimentos independentes. ${ }^{*} \mathrm{P}<0.05,{ }^{* *} \mathrm{P}<0,01$ $e^{* * *} P<0,001$. 


\section{3 - Não houve alterações morfológicas significativas nas linhagens tumorais de pâncreas tratadas com os derivados de quinolonas}

Mudanças no padrão morfológico das células podem traduzir em uma interferência metabólica com o comprometimento fisiológico normal celular. Tais mudanças podem interferir na homeostase celular e modificar os pontos de adesão focal com o subsequente arredondamento celular. Este efeito pode ser seguido ou não do rompimento celular e/ou da fragmentação em corpos apoptóticos. No contexto do nosso ensaio, tais mudanças representariam um efeito citotóxico e antitumoral para os modelos celulares empregados.

Os quatro derivados de quinolonas utilizados não foram capazes de induzir nenhuma alteração morfológica observareis pela microscopia de campo claro nas duas linhagens tumorais avaliadas, tratadas na concentração de $100 \mu \mathrm{M}$ nos períodos de tempo de 24, 48 e $72 \mathrm{~h}$ em relação aos seus respectivos controles negativos (Figuras 12 e 13).

O número de células aderidas e sua morfologia se mantiveram semelhantes nas células tratadas e nas células controle. Em um outro nível de avaliação, os resultados se repetem, nos mostrando nenhum efeito citotóxico sobre os modelos celulares empregados. 


\section{CAPAN - 2}

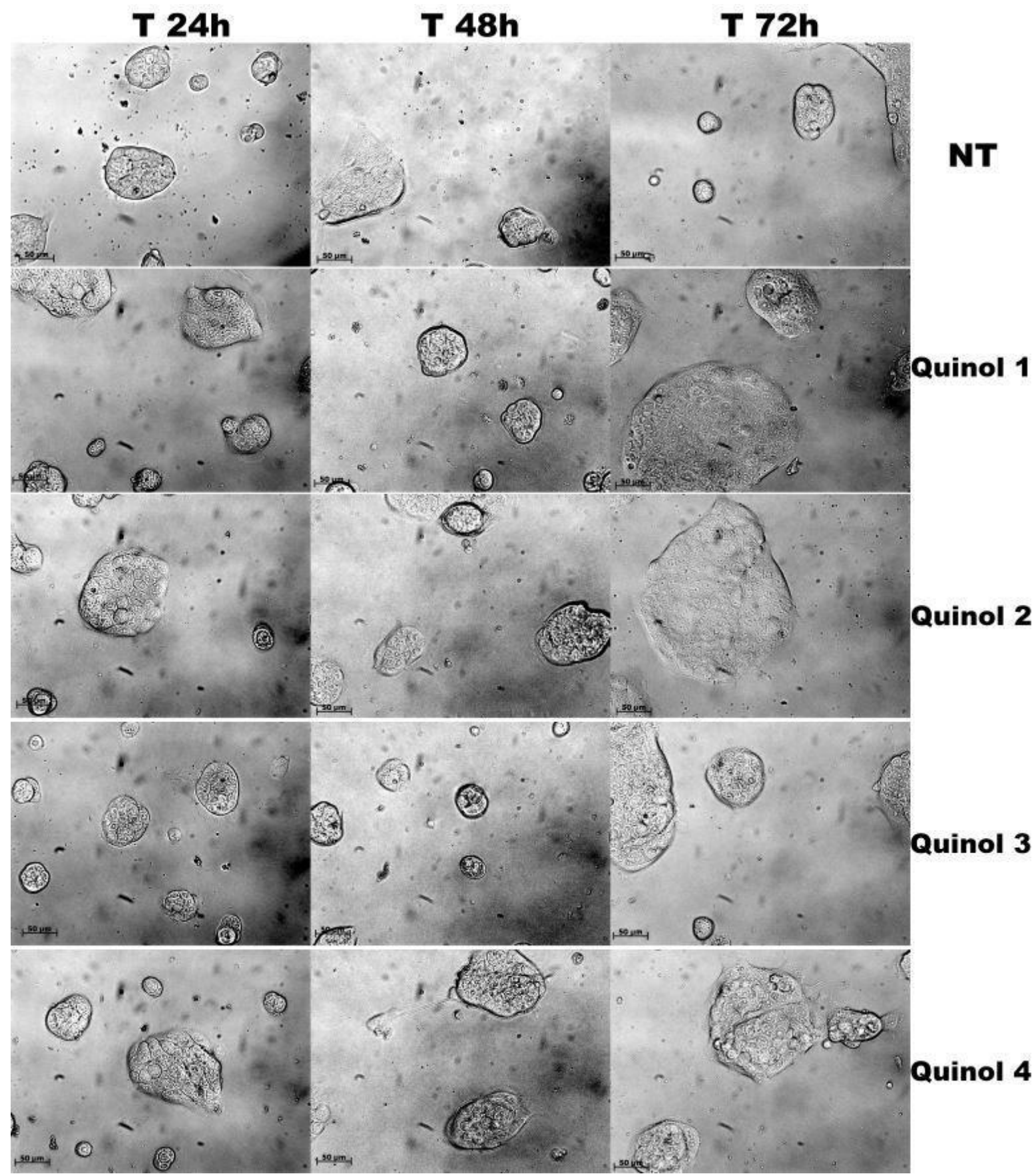

Figura 12. Análise morfológica das células da linhagem tumoral CAPAN - 2 tratadas com os quatro derivados de quinolonas nos períodos de tempo de 24,48 e $72 \mathrm{~h}$. Não se observa modificações morfológicas nas células tratadas com os derivados aqui avaliados. Imagens obtidas por microscopia de campo claro na objetiva de 10X. Barras de referência $50 \mu \mathrm{m}$. 


\section{PANC - 1}

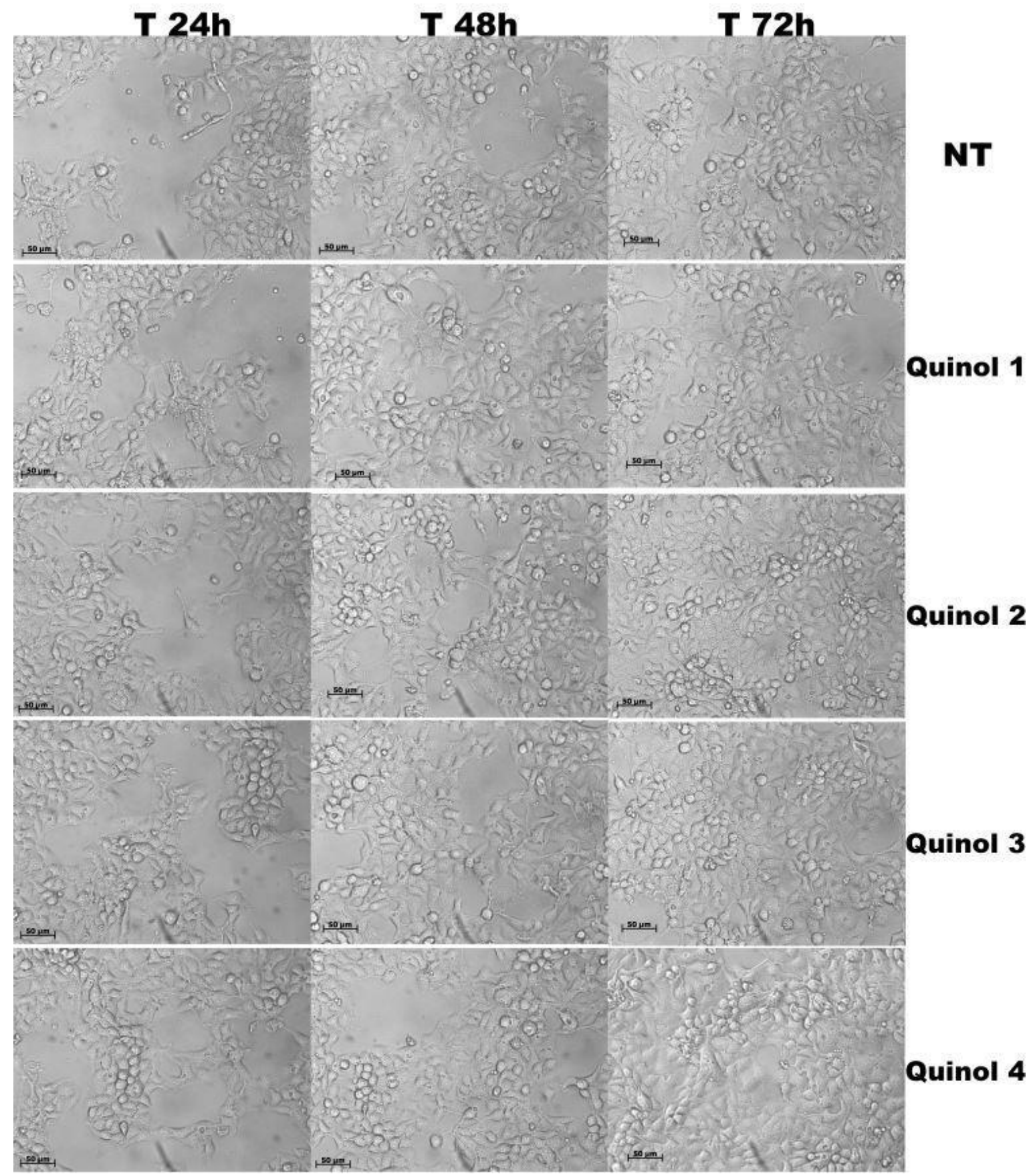

Figura 13. Análise morfológica das células da linhagem tumoral PANC -1 tratadas com os quatro derivados de quinolonas nos períodos de tempo de 24,48 e $72 \mathrm{~h}$. Não se observa modificações morfológicas nas células tratadas com os derivados aqui avaliados. Imagens obtidas por microscopia de campo claro na objetica de 10X. Barras de referência $50 \mu \mathrm{m}$. 


\section{4 - A proliferação das linhagens tumorais de pâncreas não foi inibida pelos derivados}

de quinolonas

Um dos principais eventos celulares relacionados a manutenção e perpetuação de células tumorais, é a elevada taxa de proliferação celular da maioria de suas subpopulações. Esta característica é observada virtualmente em todos os tipos de cânceres. Para avaliar a provável interferência com proliferação celular, as amostras foram tratadas e marcadas com o marcador comercial padrão para este tipo de análise, CFSE.

O tratamento com os quatro derivados de quinolonas não foram capazes de induzir de forma estatisticamente significativa a inibição da proliferação celular das linhagens tumorais de pâncreas na concentração de $100 \mu \mathrm{M}$ por um período de 24h (Figuras 14 e 15).

$\mathrm{Na}$ linhagem tumoral CAPAN - 2 o índice de proliferação do derivado Quinol 2 diminuiu de forma branda, porém não significativo estatisticamente. Na linhagem tumoral PANC - 1, o derivado Quinol 1 induziu também uma branda diminuição, porém sem significância estatística (Figura 16).

Esses resultados demonstram claramente que estes derivados também não apresentam nenhum tipo de atividade citostática contra as duas linhagens tumorais de câncer aqui avaliadas. 


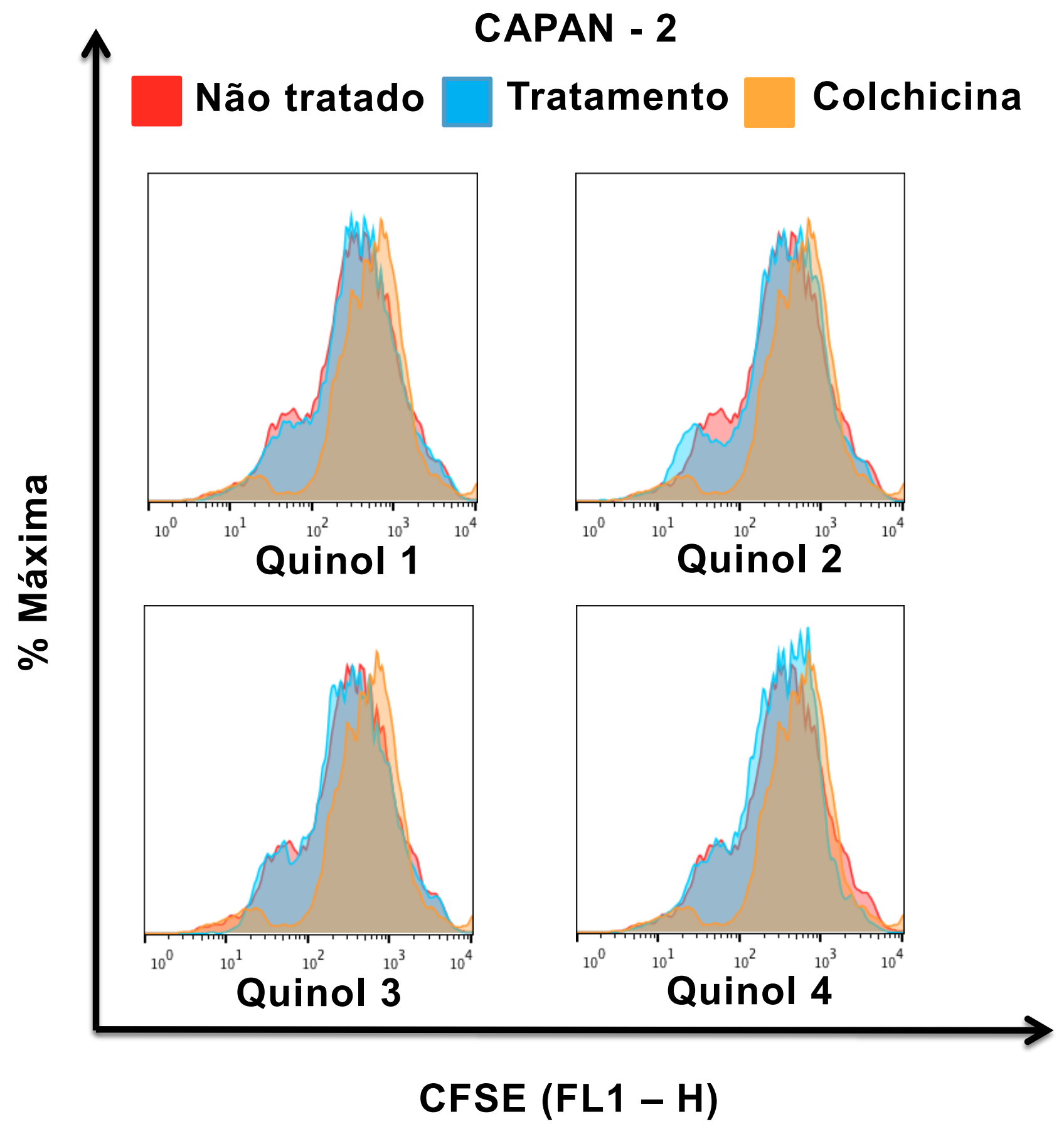

Figura 14. Avaliação da proliferação celular de células CAPAN - 2 tratadas com os derivados de quinolonas. Não houve inibição da proliferação celular em células CAPAN- 2 tratadas com quatro derivados das Quinolonas por 24h na concentração de $100 \mu \mathrm{M}$ e analisadas por citometria. Cada histograma representa a comparação entre não tratado (vermelho) com tratamento dos derivados (azul) e colchicina (Iaranja). 


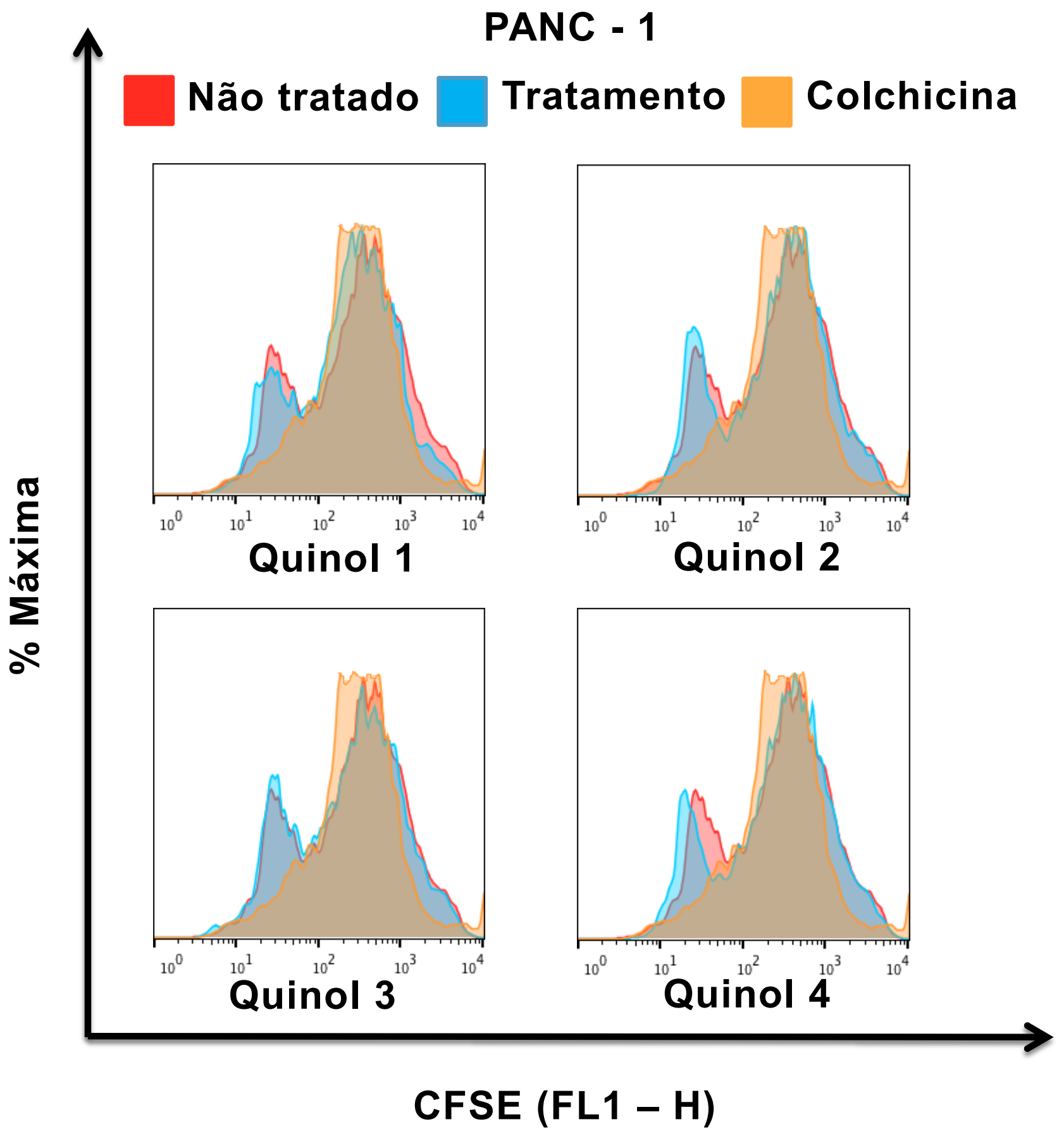

Figura 15. Intensidade de fluorescência do marcador CFSE na linhagem tumoral PANC - 1 tratada com os derivados de quinolonas. Não houve inibição da proliferação celular em células PANC - 1 tratadas com quatro derivados das Quinolonas por $24 \mathrm{~h}$ na concentração de $100 \mu \mathrm{M}$ e analisadas por citometria. Cada histograma representa a comparação entre não tratado (vermelho) com tratamento dos derivados (azul) e colchicina (Iaranja). 

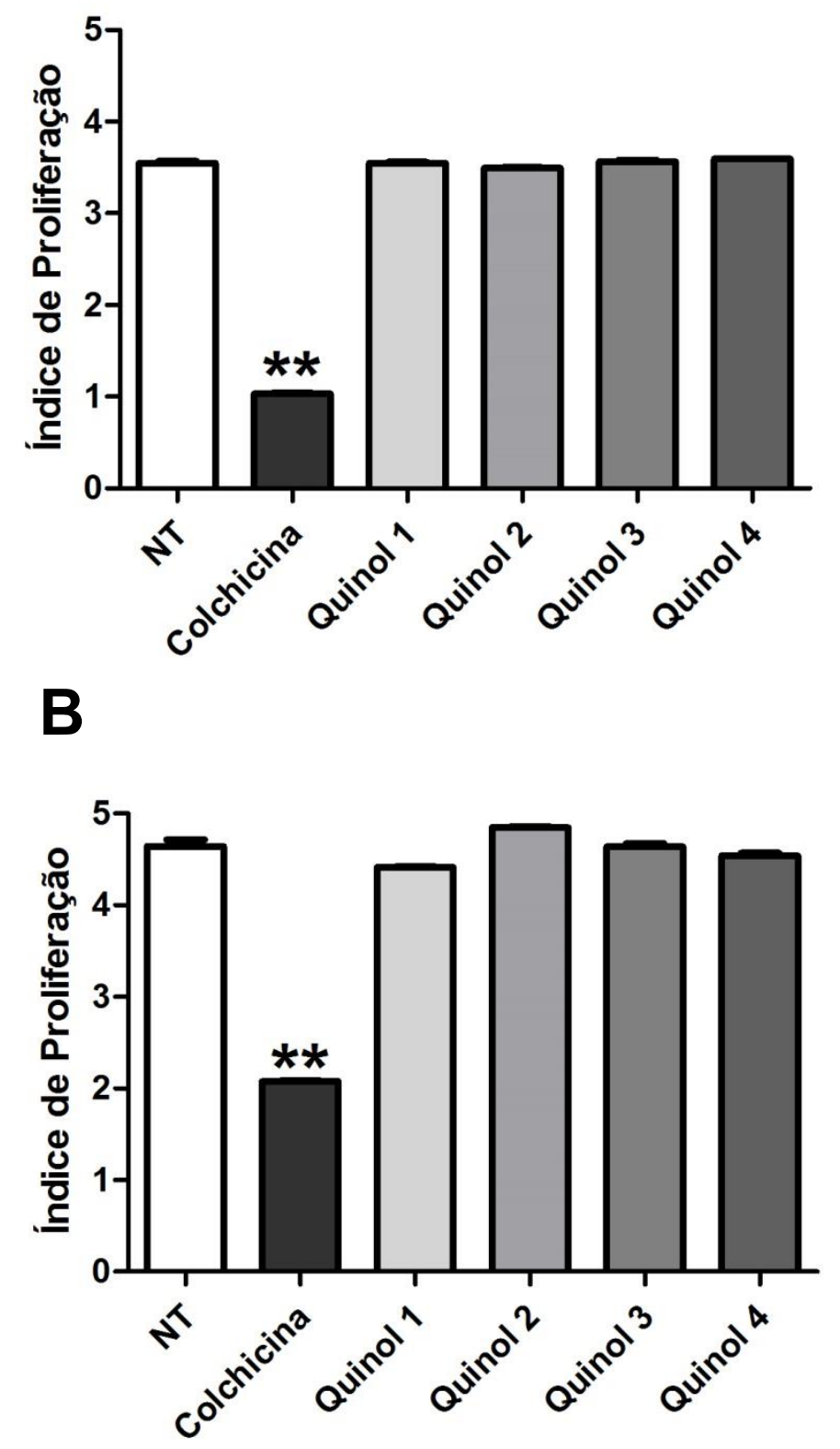

Figura 16. Índice de proliferação das linhagens tumorais CAPAN - 2 e PANC - 1 tratadas com os derivados das quinolonas. Não foi observado nenhum efeito citostático sobre as células CAPAN - 2 em (A) e PANC - 1 em (B) tratadas por quatro derivados de quinolona. ${ }^{*} \mathrm{P}<0,01$. 


\section{5 - Análises de presença de vesículas acídias nas linhagens tumorais de câncer do pâncreas não produziram resultados significativos com os tratamentos dos derivados de quinolonas}

A presença de vesículas acídias no citoplasma das células é um comprobatório de indução do processo autofágico celular que é iniciado pela ativação da proteína RAS. Essa análise é feita por marcação das células por Laranja de Acridina (AO) que, quando excitada por luz azul, produz uma fluorescência vermelha (Figuras 17 e 18).

Os resultados obtidos mostraram que os quatro derivados de quinolonas não reduziram significativamente a formação do processo autofágico celular, avaliados através da presença de vesículas acídias, nas duas linhagens tumorais de pâncreas no período de 24h (Figuras 17 e 18).

Houve um aumento tênue da quantidade de vesículas acídias quando aplicado o derivado Quinol 1 e uma diminuição tênue quando aplicado o derivado Quinol 4 na linhagem tumoral PANC - 1, porem ambas não são estatisticamente significativas. Na linhagem tumoral CAPAN - 2, o resultado da presença de vesículas acídias foi inverso ao da linhagem tumoral CAPAN - 2. O derivado Quinol 4 induziu um aumento tênue da quantidade de vesículas acídias, e o derivado Quinol 1 uma diminuição tênue da quantidade de vesículas acídias, em ambos os casos os resultados também não foram estatísticamente significativos (Figura 19).

Esse resultado aponta para a provável inatividade destes compostos como potenciais inibidores da proteína RAS, nas duas linhagens celulares testadas (CAPAN - 2 e PANC - 1). 


\section{PANC - 1}

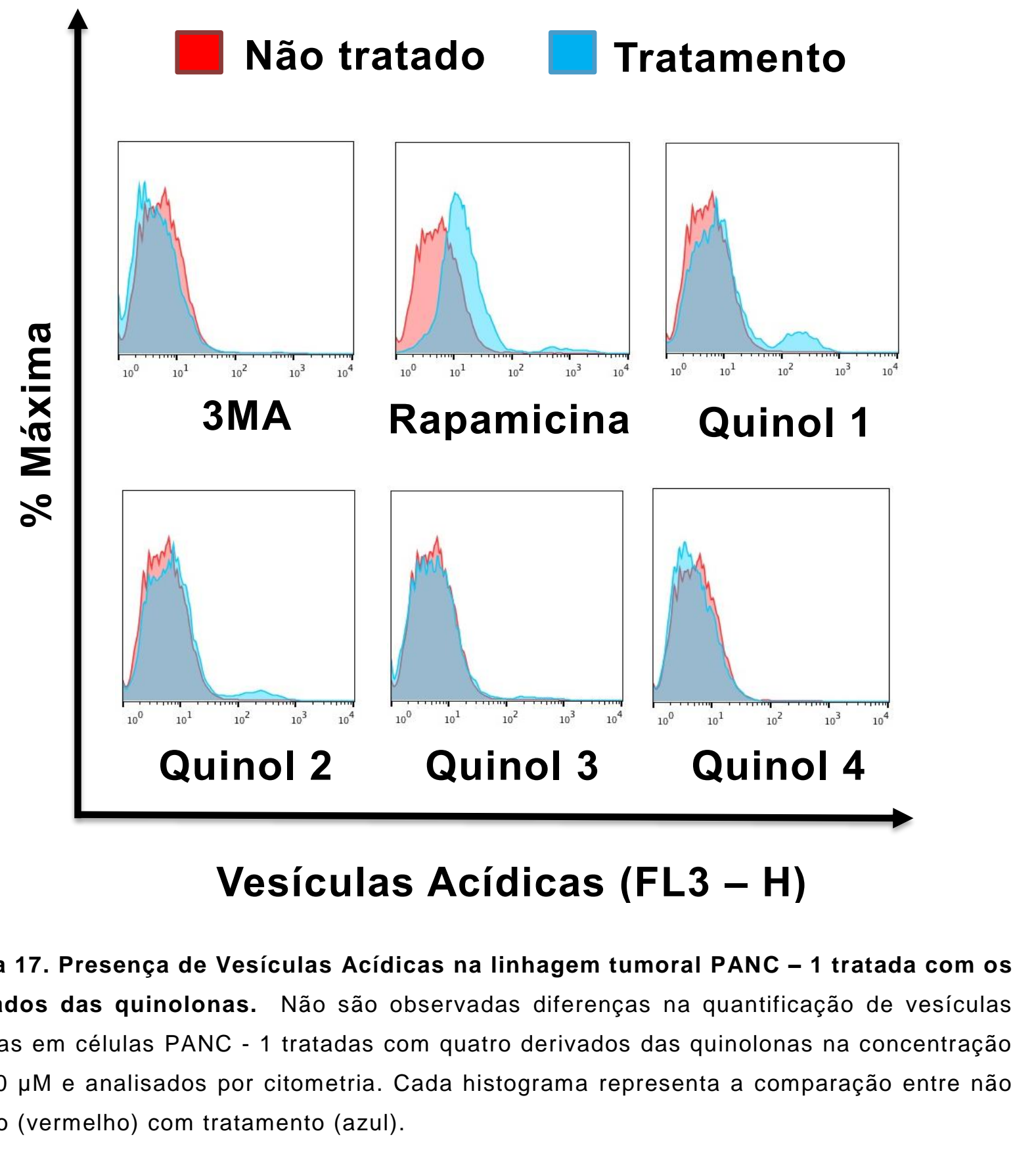




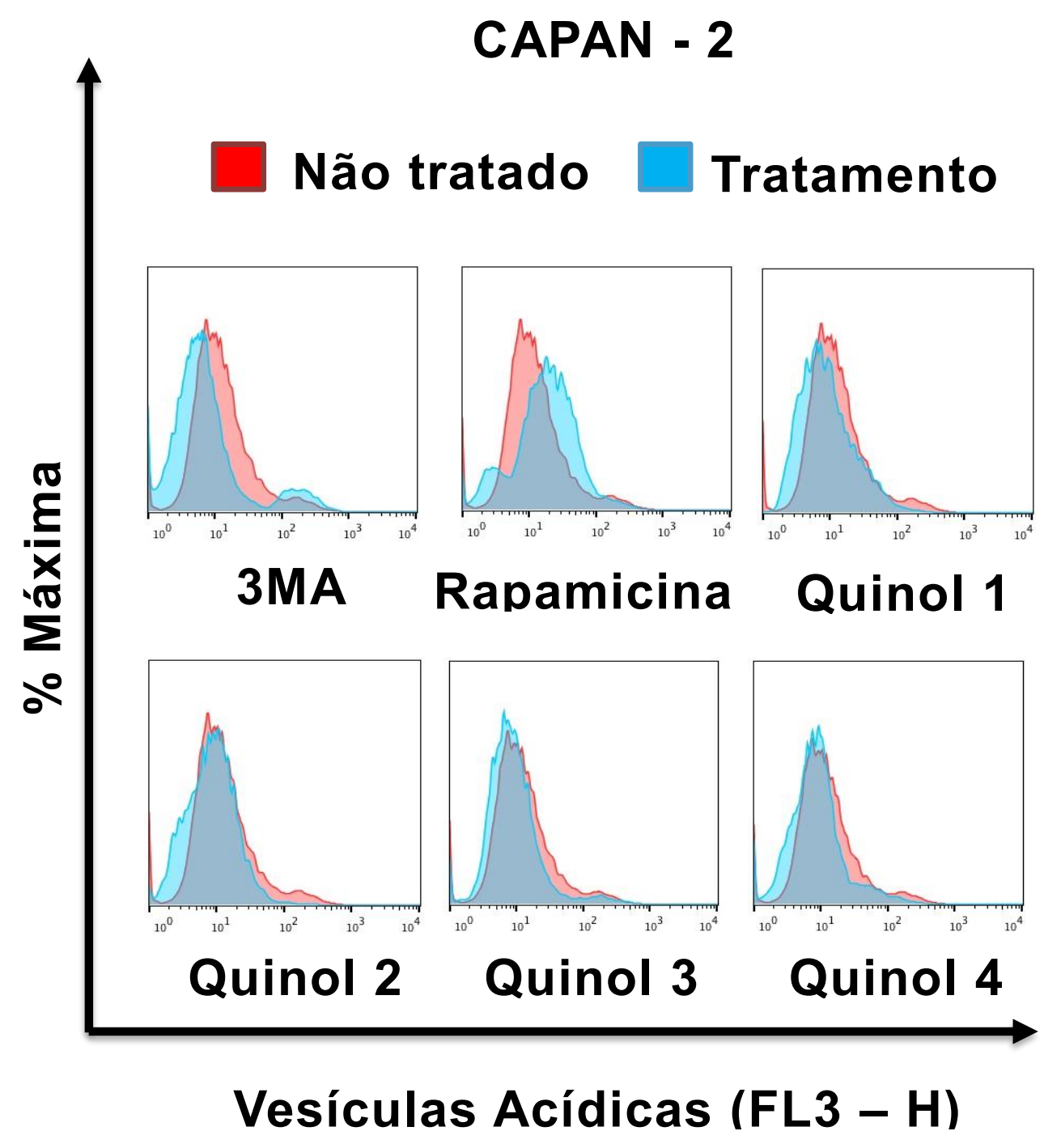

Figura 18. Presença de Vesículas Acídicas na linhagem tumoral PANC - 1 tratada com os derivados das quinolonas. Não são observadas diferenças na quantificação de vesículas acídicas em células CAPAN-2 tratadas com quatro derivados das quinolonas na concentração de $100 \mu \mathrm{M}$ e analisados por citometria. Cada histograma representa a comparação entre não tratado (vermelho) com tratamento (azul). 

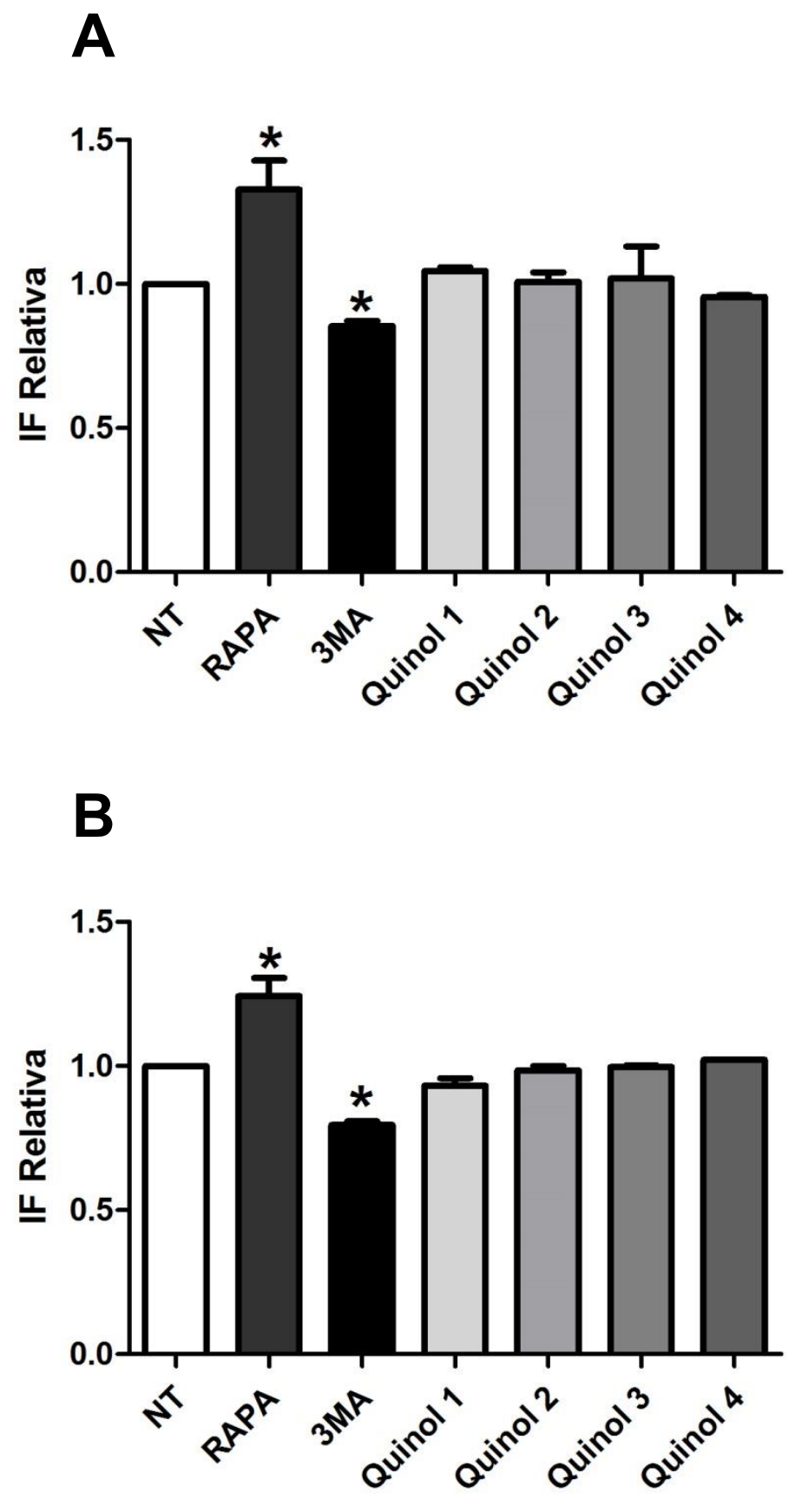

Figura 19. Quantificação pela intensidade de fluorescência (IF) das linhagens tumorais tratadas com os derivados das quinolonas. Não houve diferença estatisticamente significativa para nenhuma variação observada pelos tratamentos com os derivados das quinolonas. A. Células PANC - 1. B. Células CAPAN - 2. ${ }^{\star} P<0,05$. 


\section{6 - Avaliação da capacidade de migração das células tumorais de pâncreas. Não foi observada inibição na migração celular nas células tratadas com os derivados das Quinolonas}

A capacidade de migração das células tumorais é um dos principais fatores relacionados ao agravamento da doença, pois é determinante para o processo de estabelecimento das metástases. Compostos que apresentem a propriedade de inibição da migração celular são potenciais candidatos para uso no tratamento do câncer mesmo que seja como uma droga adjuvante.

Para a análise de uma possível inibição da migração celular das linhagens tumorais tratadas com os derivados de quinolonas, foi empregada a metodologia de wound healing cuja proposta é a de mimetizar a migração celular durante a cicatrização de feridas in vivo. O ensaio consiste na realização de uma raspagem na superfície de uma camada de células semi confluentes, e avaliação do fechamento desta lesão, no período de $72 \mathrm{~h}$, a partir de aquisição de imagens por microscopia de campo claro em intervalos de 12h. (Figuras 20 a 26).

Apesar de diferenças nas taxas de migração celular nas duas linhagens tumorais tratadas com os quatro derivados de quinolonas, nenhum dos resultados foi estatisticamente significativo.

Na linhagem tumoral CAPAN - 2 o derivado Quinol 3 induziu uma diminuição branda da migração celular a partir do intervalo de tempo de 36h. Os derivados Quinol 1 e Quinol 2 induziram uma diminuição branda da migração no intervalo de tempo de $72 \mathrm{~h}$ (figura 22). Os derivados Quinol 1, Quinol 2 e Quinol 4 induziram um aumento da migração a partir do período de intervalo de $12 \mathrm{~h}$ até o intervalo de $60 \mathrm{~h}$ (figuras 20 e 21). No intervalo de período de $72 \mathrm{~h}$ apenas o derivado Quinol 4 induziu o aumento de migração celular (Figura 22). Todos os resultados não foram estatisticamente significativos (Figura 26A)

Na linhagem tumoral PANC - 1 o derivado Quinol 1 induziu uma diminuição da migração celular no intervalo de tempo de $60 \mathrm{~h}$ (figura 24). Os derivados Quinol 2 e Quinol 4 induziram uma diminuição da migração celular no intervalo de tempo de $72 \mathrm{~h}$ (figura 25). Os derivados Quinol 2 e Quinol 4 induziram o aumento da migração celular a partir do período de tempo de $12 \mathrm{~h}$ até o período de tempo de $48 \mathrm{~h}$ (figura 23). Todos os resultados obtidos nessa linhagem não foram estatisticamente significativos (Figura 26B)

Os resultados obtidos em ambas as linhagens tumorais estabelecem a não inibição da migração celular nos modelos aqui testados quando tratados por estes quatro derivados das Quinolonas. 


\section{CAPAN - 2}

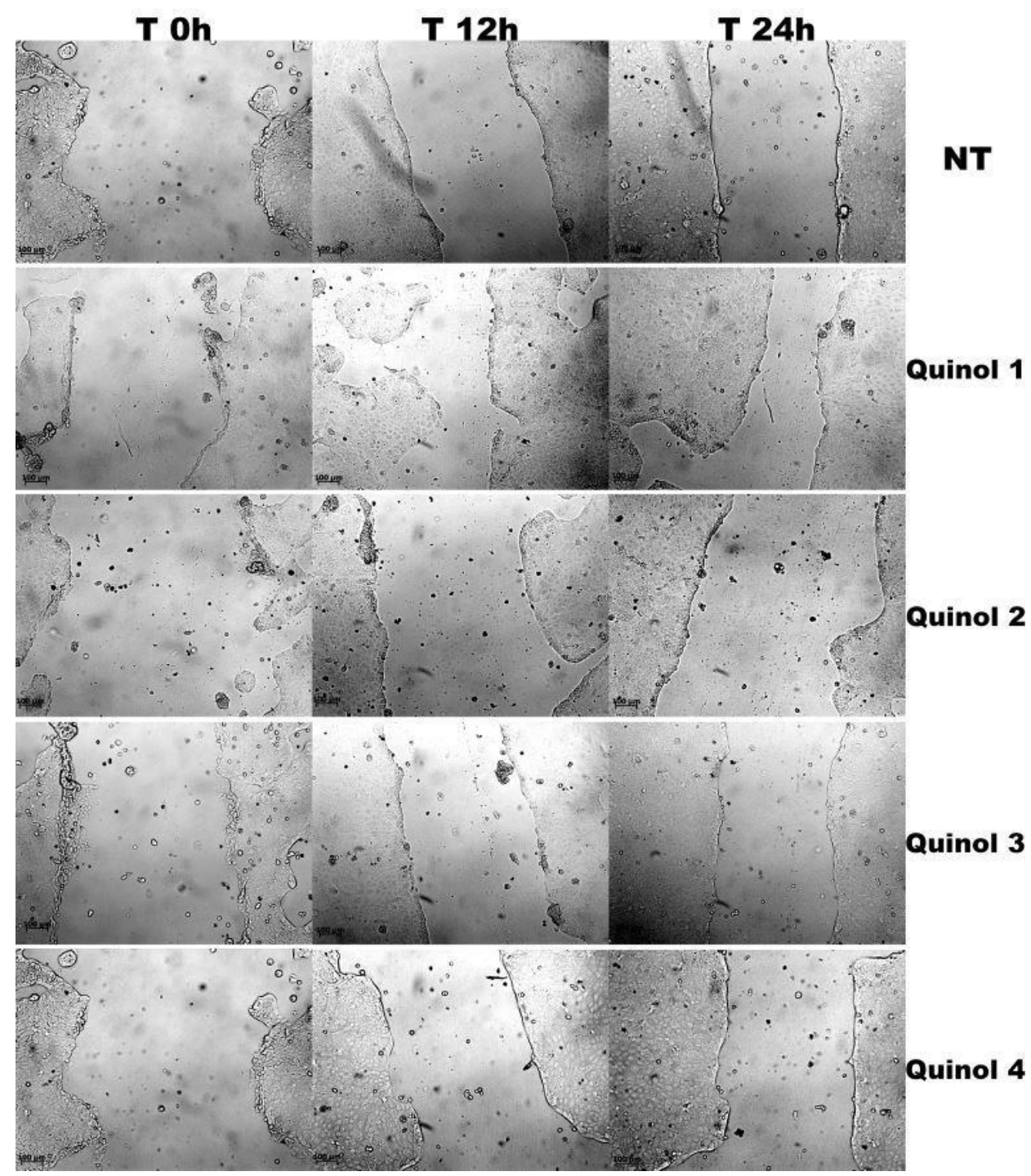

Figura 20. Avaliação da migração celular em células tumoral CAPAN - 2 nos intervalos de tempo de 0, 12 e 24h. Não foram observadas inibições da migração celular nas células tratadas com os quatro derivados das Quinolonas na concentração de $100 \mu \mathrm{M}$ e analisadas por microscopia de campo claro. Barras de $100 \mu \mathrm{m}$. 


\section{CAPAN - 2}

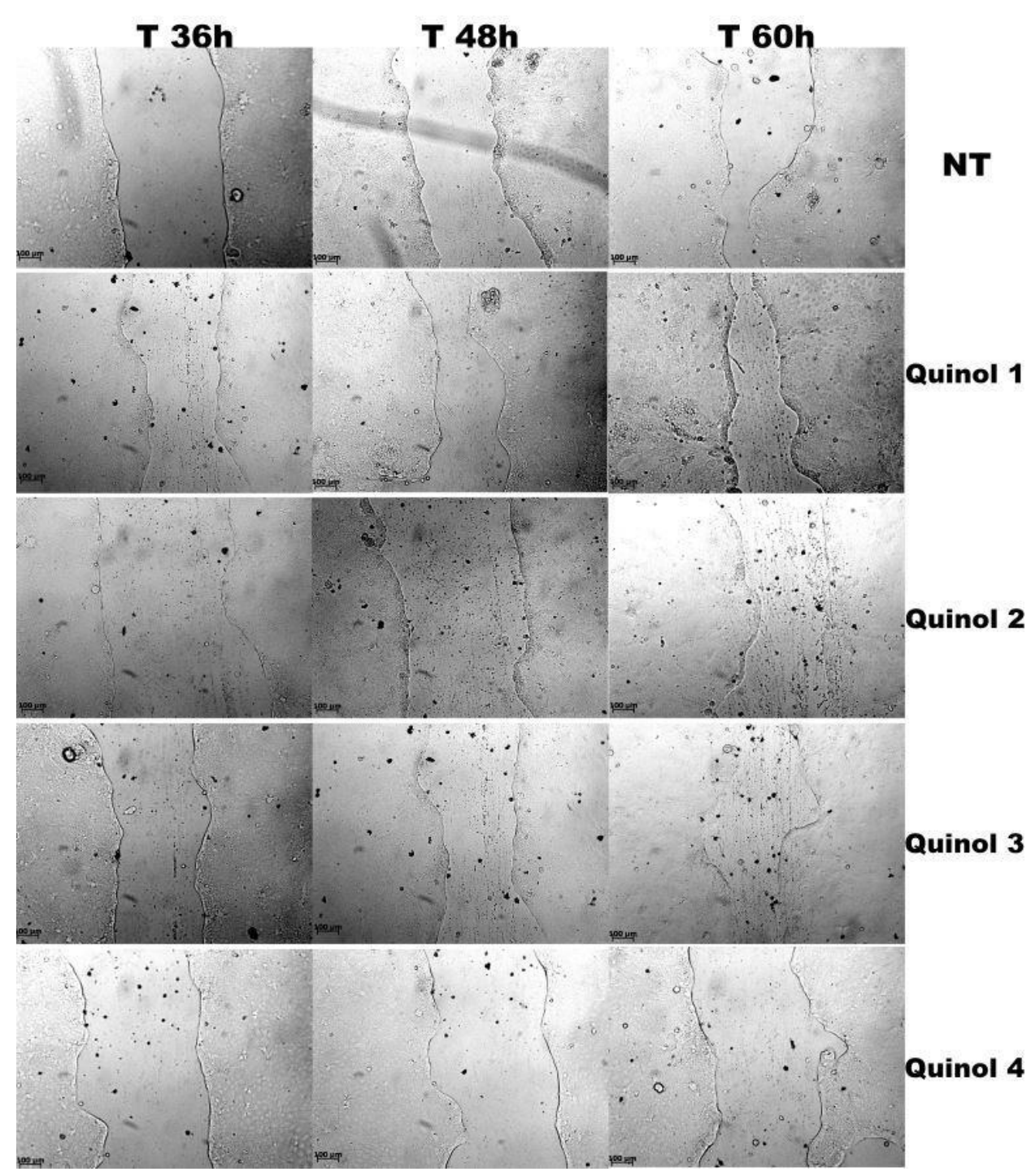

Figura 21. Avaliação da migração celular em células tumoral CAPAN - 2 nos intervalos de tempo de 36, 48 e 60h. Não foram observadas inibições da migração celular nas células tratadas com os quatro derivados das Quinolonas na concentração de $100 \mu \mathrm{M}$ e analisadas por microscopia de campo claro. Barras de $100 \mu \mathrm{m}$. 


\section{CAPAN - 2}

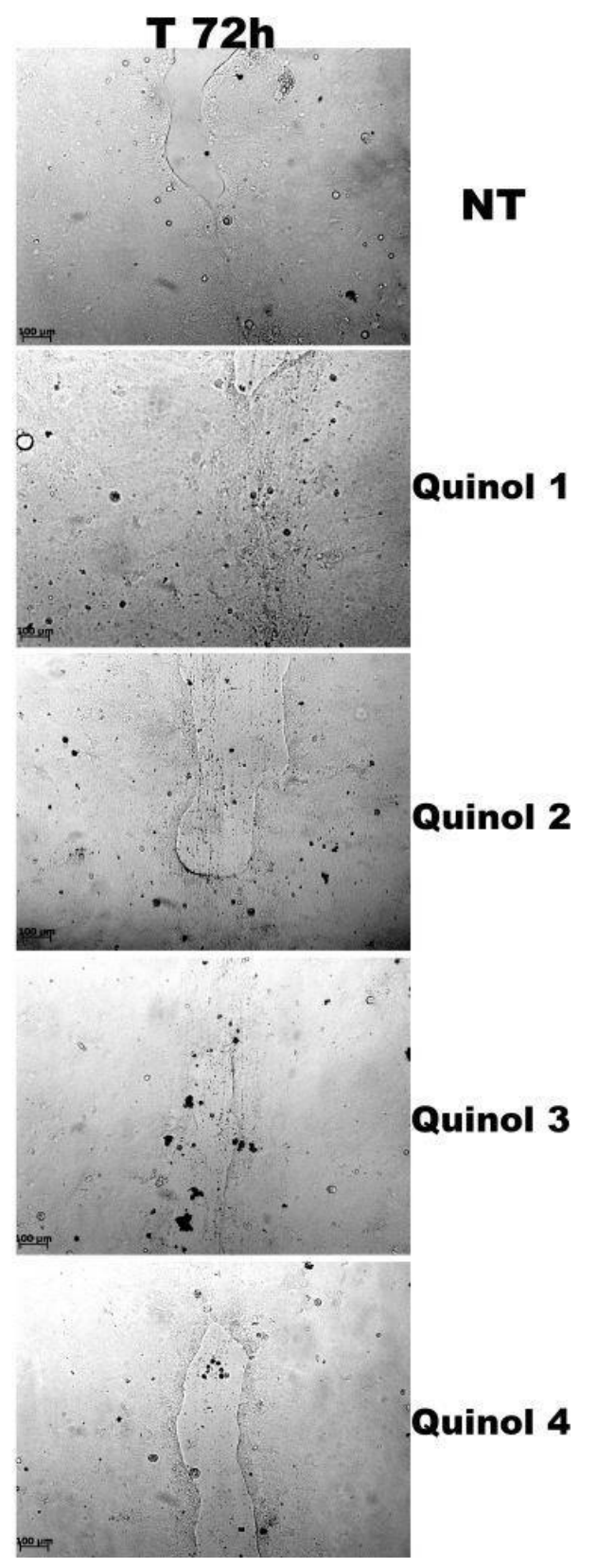

Figura 22. Avaliação da migração celular em células tumoral CAPAN - 2 no intervalo de tempo de $72 \mathrm{~h}$. Não foram observadas inibições da migração celular nas células tratadas com os quatro derivados das Quinolonas na concentração de $100 \mu \mathrm{M}$ e analisadas por microscopia de campo claro. Barras de $100 \mu \mathrm{m}$. 


\section{PANC - 1}

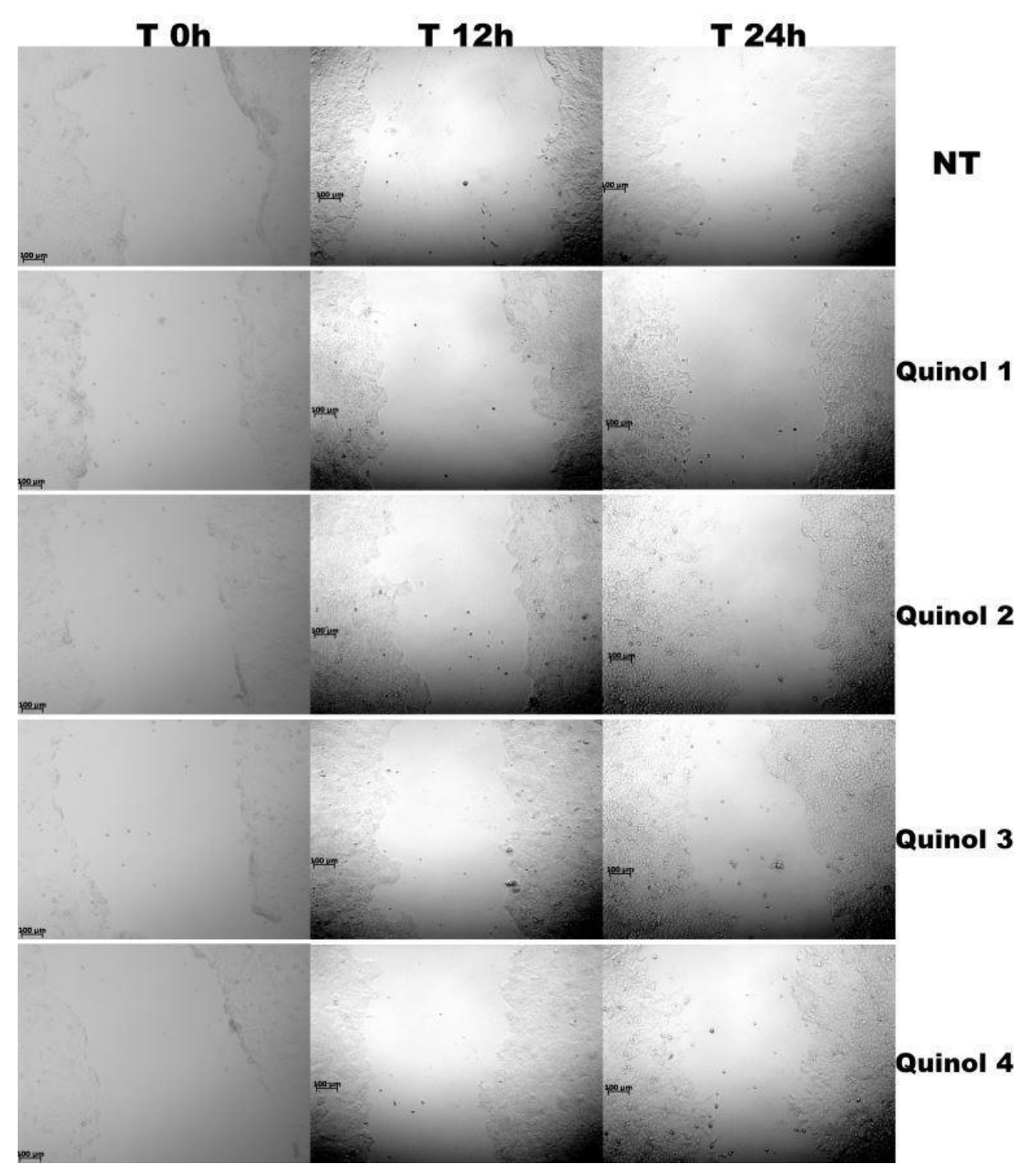

Figura 23. Avaliação da migração celular em células tumoral PANC - 1 no intervalo de tempo de 0, 12 e 24h. Não foram observadas inibições da migração celular nas células tratadas com os quatro derivados das Quinolinas na concentração de $100 \mu \mathrm{M}$ e analisadas por microscopia de campo claro. Barras de $100 \mu \mathrm{m}$. 


\section{PANC - 1}

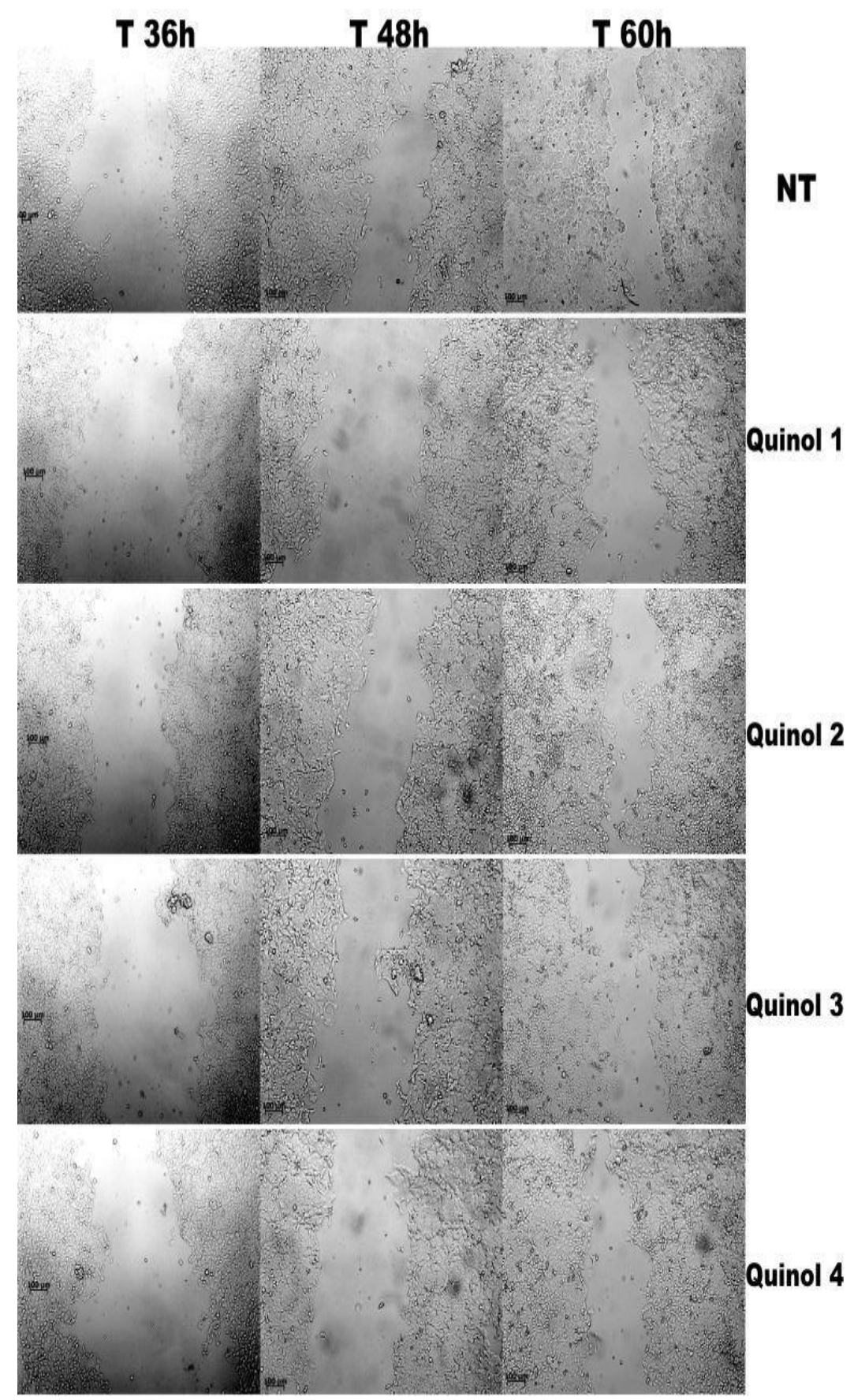

Figura 24. Avaliação da migração celular em células tumoral PANC - 1 nos intervalos de tempo de 36, 48 e 60h. Não são observadas inibições da migração celular nas células tratadas com os quatro derivados das Quinolinas na concentração de $100 \mu \mathrm{M}$ e analisadas por microscopia de campo claro. Barras de $100 \mu \mathrm{m}$. 


\section{PANC - 1}

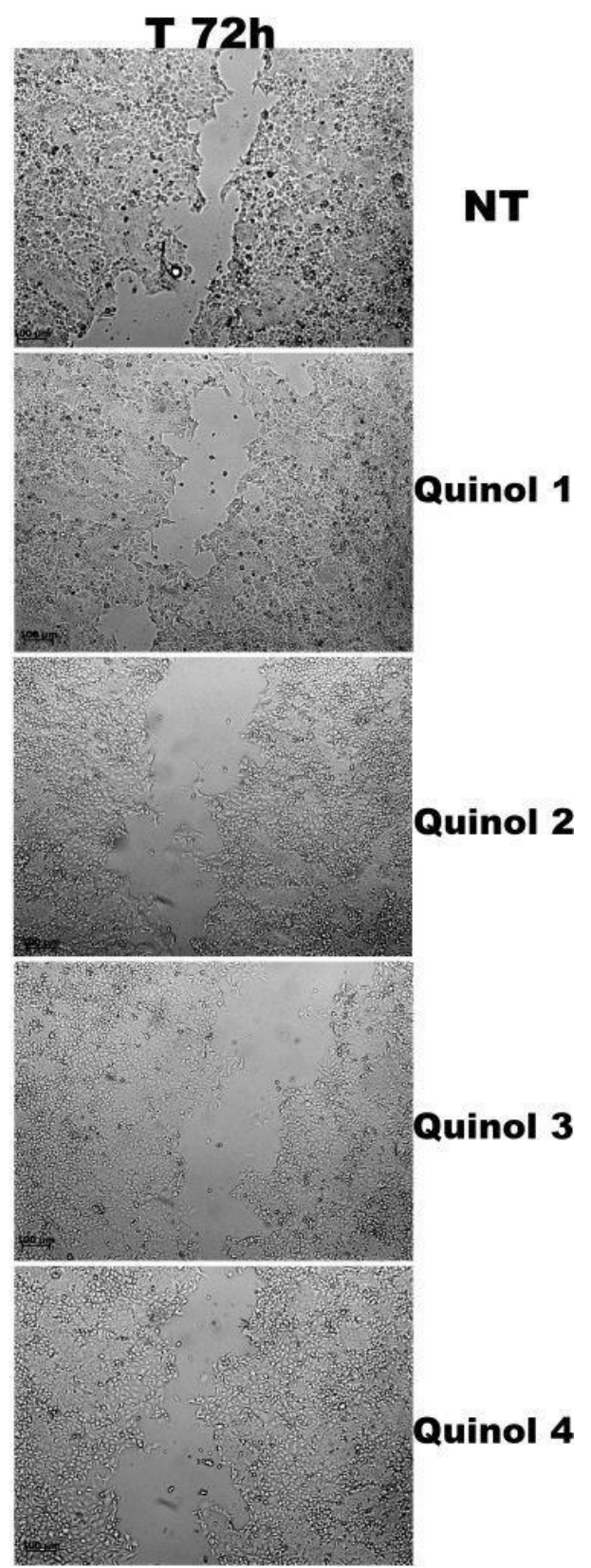

Figura 25. Avaliação da migração celular em células tumoral PANC - 1 no intervalo de tempo de $72 \mathrm{~h}$. Não são observadas inibições da migração celular nas células tratadas com os quatro derivados das Quinolinas na concentração de $100 \mu \mathrm{M}$ e analisadas por microscopia de campo claro. Barras de $100 \mu \mathrm{m}$. 


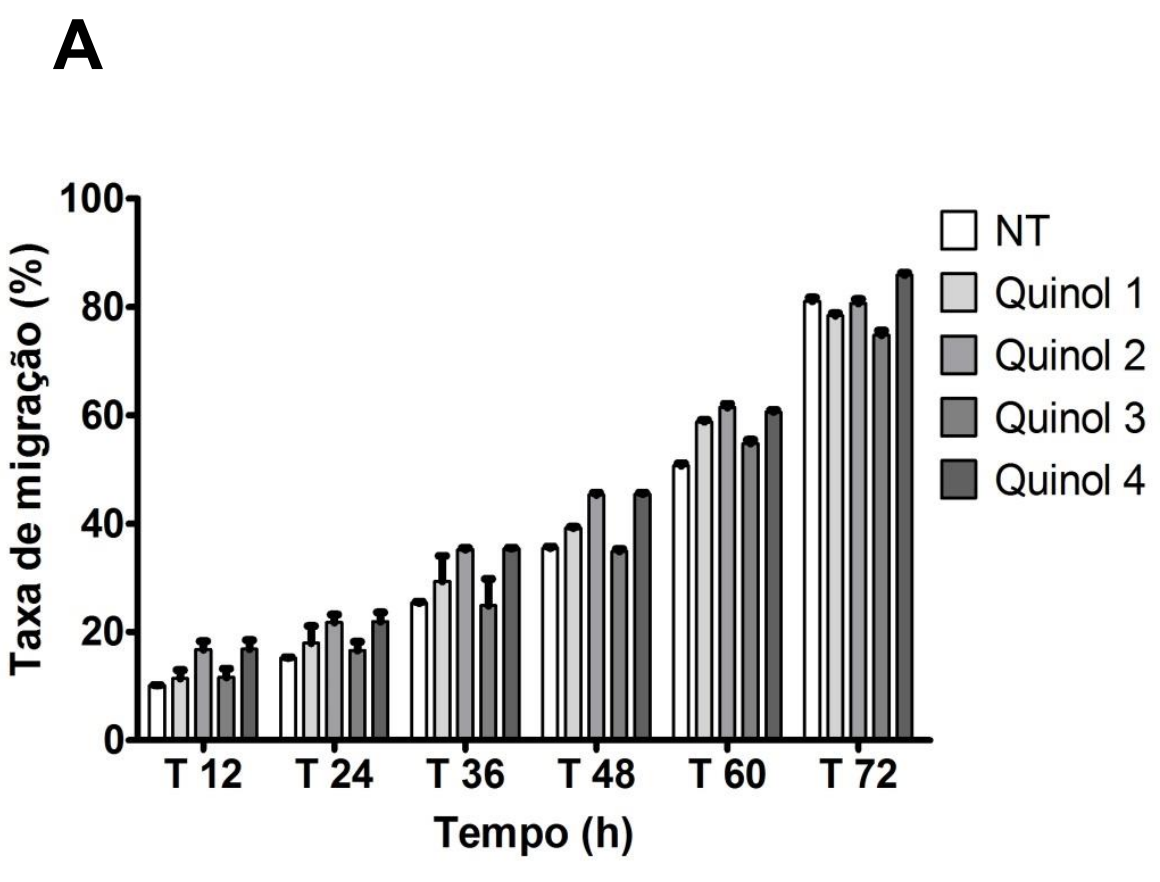

\section{B}

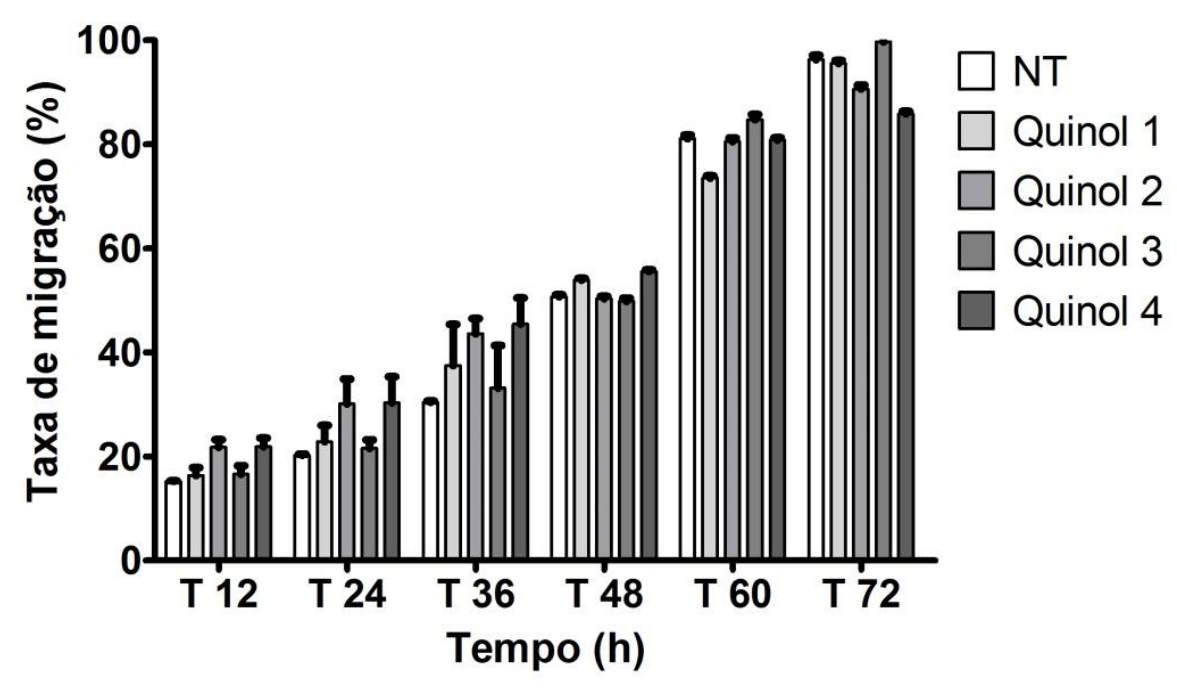

Figura 26. Avaliação quantitativa da taxa de migração das células tumorais em intervalos regulares de $\mathbf{1 2}$ horas por um período de $\mathbf{7 2}$ horas sob tratamento com os derivados de quinolonas. Não foi encontrada diferença estatisticamente significativa entre os diferentes tratamentos em relação aos controles no período avaliado A. Células CAPAN - 2. B. Células PANC - 1. 


\section{6. - DISCUSSÃO}

A obtenção de novos fármacos que sejam mais efetivos, com atividade altamente específica, menos citotóxicos às células normais e de baixo custo, são os objetivos mais procurados para os tratamentos de câncer. Existe atualmente um esforço internacional em torno da promoção do desenvolvimento de drogas contra o câncer que vem gerando uma gigantesca rede de informações que auxiliam a pesquisadores de todo o mundo na imersão nesta busca. Com base em bases de dados de acesso livre, identificamos as quinolonas como moléculas promissoras, devido ao seu histórico de estudo e análises de suas propriedades antitumorais (GURTOWSKA; KLOSKOWSKI; DREWA, 2010, KHAN et al., 2016, SUN et al., 2013). Já foi demonstrado que derivados de quinolonas são capazes de inibir a mitose e induzir células tumorais a apoptose, células estas pertencentes a diferentes tipos de cânceres (GURTOWSKA; KLOSKOWSKI; DREWA, 2010, KHAN et al., 2016, SUN et al., 2013).

As proteínas RAS participam na cascata de ativação de diversas vias metabólicas para o funcionamento normal das células, marcadamente atuando como centro de controle da proliferação e migração celular. Como a mutação dessa proteína (KRAS) é o principal fator indutor da transformação celular no câncer de pâncreas (BERNDT; HAMILTON; SEBTI, 2011, VASAN; BOYER; HERBST, 2014, SANTARPIA, 2017, COX et al., 2014), nosso grupo produziu nove derivados das quinolonas com propriedade predita computacionalmente de inibição do evento de prenilação das proteínas RAS. A prenilação é a modificação pós-tradicional essencial para que as proteínas RAS entrem em seu estado ativo e desempenhem suas funções celulares (SHEN et al., 2014, CARR, 2016, VASAN; BOYER; HERBST, 2014). Este trabalho teve como objetivo realizar a prova de conceito a cerca da atividade antitumoral de nove derivados das quinolonas, em face de sua provável atividade de inibição de proteínas RAS. Desta forma os modelos escolhidos foram linhagens celulares do câncer de pâncreas (CAPAN - 2 e PANC - 1) nas quais a proteína KRAS está mutada, exercendo continuamente sua atividade de fosforilação de forma independente de sinal, sendo o cerne da tumorogênese (VASAN; BOYER; HERBST, 2014, RAJASEKHARAN; RAMAN, 2013; VETTER; WITTINGHOFER, 2007). Este foi o modelo mais adequado para nossos ensaios, visto que a simples determinação do índice de proliferação celular após o tratamento com os derivados das quinolonas nos deu resposta sobre o estado de ativação da KRAS nestas células. Inicialmente avaliamos se os derivados de quinolonas apresentavam atividade citotóxica sobre as linhagens tumorais de pâncreas em comparação com as células normais. Nossos resultados demonstraram que os derivados por nós produzidos, não foram capazes de induzir qualquer tipo de citotoxicidade nos modelos testados, nem dose e nem tempo dependente dentro de um período de 72 horas. Desta forma não foi possível determinar um $\mathrm{IC}_{50}$ para os compostos testados, visto que não foram citotóxicos mesmo quando empregado a elevada concentração de $1 \mathrm{mM}$. Estes resultados contrastam com os obtidos por SUN et al. e SARKER et al (SUN et al., 2013, SARKER et al., 2014) os quais empregando outras classes de derivados das quinolonas observaram atividade citotóxica contra os modelos de câncer de fígado, Hep3B2.1-7, e câncer colo retal, HT-29. Nestes casos a atividade citotóxica 
observada foi acompanhada ainda da indução de morte celular por apoptose (SUN et al., 2013, SARKER et al., 2014), o que serviu de base para a proposição desta classe de compostos como promissores para o tratamento do câncer (SUN et al., 2013, SARKER et al., 2014).

Em nosso trabalho, também foi avaliado o provado perfil de morte celular que seria induzido pelo tratamento com os derivados das quinolonas. Estas análises foram feitas mesmo após o resultado negativo da citotoxicidade. A explicação esta no fato de que a inibição da proteína RAS poderia não levar a um declínio metabólico imediato, portanto, não seria detectada pelo ensaio de MTT, o qual quantifica a atividade da enzima oxidoredutase dependente de NADPH, o que indiretamente demonstra a normalidade da atividade metabólica celular devido ao fluxo de NADPH (BERRIDE et al., 2005).

Os processos de morte celular são eventos regulados de forma multifatorial, com vias de ativação conhecidas que atuam mesmo em condições metabólicas normais nas celulas (BIANCHI, 2014, BRASÓ-MARISTANY et al., 2016). Com base no acima expostos, avaliamos qual perfil de morte celular seria induzido pelo tratamento com os derivados das quinolonas. Os resultados obtidos mostraram que nenhum dos derivados de quinolonas foi capaz de induzir a morte celular de forma que consideramos satisfatório para sua utilização como agente antitumoral. Embora os resultados tenham apresentados significância estatística, os valores ficaram restritos a menos de $1 \%$ não tendo chegado a $3 \%$ no melhor resultado. Esta margem numérica inviabiliza a sua aplicação como agente antitumoral uma vez que de 97 a $99 \%$ das células tumorais não são afetadas pela atividade destes compostos. De forma muito interessante, estes resultados também demonstram o forte viés que o tratamento estatístico pode dar a resultados pouco promissores quando as diferenças ficam restritas a valores praticamente desprezíveis. Outros autores como YADAV et al, 2015 e BRAJSA et al, 2015, empregando diferentes derivados das quinolonas, observaram a indução de morte celular por apoptose. No entanto a estrutura molecular destas moléculas é bastante diferente das estruturas moleculares testadas por nós.

Levando ainda em consideração da possibilidade de inibição da atividade da proteína RAS, avaliamos fenótipos celulares como a proliferação celular e a autofagia. Estes eventos são amplamente descritos como dependentes da atividade RAS (LIU et al, 2017, MAO et al., 2017), sendo que o descontrole da proliferação das células no câncer do pâncreas é a característica essencial da transformação celular e exclusivamente dependente da KRAS mutada nas células (LUNKE et al., 2017, VARGA et al., 2017). Já a autofagia consiste na reciclagem de proteínas e organelas danificadas para manutenção da homeostase citosólica sendo considerada de forma duplas: um fator de sobrevivência para células tumorais ou como um supressor tumoral (YANG, 2011; RAO, 2014). Nossos resultados demonstraram que não houve diferenças na indução de autofagia nas células e também não houve declínio da taxa de proliferação celular. Estes resultados estabelecem a total ausência de atividade inibitória sobre a proteína KRAS dos derivados das quinolonas aqui avaliados. Neste contexto, o resultado do ensaio de proliferação celular elimina a possibilidade do emprego destes compostos como agentes citostáticos. Drogas citostáticas são importantes adjuvantes no tratamento do câncer 
uma vez que o processo de proliferação celular é considerado como o principal fator de iniciação e desenvolvimento do tumor (WANG et al., 2014, KIRCHNER, 2014).

Mesmo após toda sequência de resultados negativos, prosseguimos com as análises, realizando ensaios para avaliar modificações na morfologia das células e sua capacidade de migração. Como a migração celular é um evento controlado por muitos fatores, e esta relacionado a atividade RAS (MAO et al., 2017, PARK et al., 2016) sendo ainda um dos fatores essenciais para o estabelecimento das metástases e consequente agravamento da doença (MAO et al., 2017, PARK et al., 2016); Este ensaio consolidaria nossa conclusão a cerca destes compostos. Neste ponto, as alterações morfológicas se presentes poderiam indicar atividade citotóxica independente do alvo predito (proteína RAS). Novamente nossos resultados foram negativos tanto para a inibição da migração celular quanto para a indução de modificações morfológicas perceptíveis por microscopia de campo claro. Desta forma, ficou estabelecido que este conjunto de derivados não apresentam qualquer tipo de atividade citotóxica ou inibitório que possa ser apropriada como atividade antitumoral contra o câncer de pâncreas. No entanto, como um átomo de hidrogênio muda completamente as propriedades de uma molécula, não é possível extrapolar estes resultados para outros derivados das quinolonas que sejam sintetizados seguindo a mesma lógica de substituição de seus radicais constituintes.

\section{7. - CONCLUSÃO E PERPECTIVAS}

Os resultados obtidos com este trabalho excluem qualquer aplicabilidade dos derivados das quinolonas aqui testad os serem empregados como agentes antitumorais contra o câncer de pâncreas. Embora em modelos computacionalmente houvesse a probabilidade de interação inibitória com a via de prenilação da proteína RAS as moléculas sintetizadas não apresentaram qualquer atividade real inibitória de diversas vias controladas pela proteína RAS no modelo in vitro do câncer de pâncreas (células CAPAN - 2 e PANC - 1). Os nossos dados também excluem a possível aplicabilidade destes compostos como adjuvantes ao tratamento do câncer, por não terem apresentado atividade citostática. Nossos dados apresentam um forte alerta quanto ao tratamento estatístico de dados, mesmo com significância estatisticamente elevada, nossos dados de indução de morte celular não puderam ser convertidos em informação útil que sustentasse a aplicabilidade destes compostos. Outro ponto importante é a reavaliação das metodologias empregadas pelo nosso grupo quanto a o racional do designe das moléculas com potencial para atividade antitumoral. Embora em outros casos tivemos sucesso nesta predição, a arquitetura atômica das quinolonas nos mostrou que a metodologia aplicada por nós pode gerar produtos sem qualquer atividade. E isto nos leva a um processo de reavaliação deste racional o que contribuirá para a implantação de métodos mais eficientes de análise e comparação de estruturas. Finalmente, aplicando as lições aprendidas com este trabalho, iremos produzir uma segunda geração de derivados de quinolonas na expectativa de que estas novas moléculas possam alcançar mesmo que parcialmente os objetivos propostos aqui. 


\section{8. - REFERÊNCIAS BIBLIOGRÁFICAS}

ABRAMS, G. "Neoplasia I". Patients and Populations: Medical Genetics - M1. University of Michigan, U.S. Retrieved 23 January 2012.

ADAMSON, E. D. Oncogenes in development. Development (Cambridge, England), v. 99, n. 4, p. 449-71, abr. 1987.

ALDRED, K. J., KERNS, R. J., \& OSHEROFF, N. Mechanism of quinolone action and resistance. Biochemistry, 53(10), 1565-1574. https://doi.org/10.1021/bi5000564. 2014.

Almeida, J.; Pedrosa, N.; Leite, J.; Fleming, T.; CARVAlho, V.; CARdoso, A. Marcadores Tumorais: Revisão de Literatura, Revista Brasileira de Cancerologia. 53(3): 305$316 ; 2007$.

ALVIM, H. G. de O. Efeito de Líquido lônico Sobre a Reação de Biginelli em Condições de Catálise Homogênea e Heterogênea Efeito de Líquido lônico Sobre a Reação de Biginelli em Condições de Catálise Homogênea e Heterogênea. 2013.

AMERICAN CANCER SOCIETY. Cancer Facts \& Figures 2016. Atlanta, Ga: American Cancer Society; 2016.

ANDERSSON, M. I., \& MACGOWAN, A. P. Development of the quinolones. The Journal of Antimicrobial Chemotherapy, 51 Suppl 1(suppl_1), 1-11. http://doi.org/10.1093/jac/dkg212. 2003.

BALL, P. Quinolone generations: natural history or natural selection? J Antimicrob Chemother 46 (suppl_3): 17-24. 2000.

BERNDT, N., HAMILTON, A. D., \& SEBTI, S. M. Targeting protein prenylation for cancer therapy. Nature Reviews. Cancer, 11(11), 775-91. http://doi.org/10.1038/nrc3151. 2011.

BERRIDGE M.V. et al. Tetrazolium dyes as tools in cell biology: new insights into their cellular reduction. Biotechnology Annual Review, 11: 127-152 (2005).

BIANCHI, M. E. Killing cancer cells, twice with one shot. Cell Death and Differentiation, 21(1), 1-2. https://doi.org/10.1038/cdd.2013.147. 2014.

BIRBRAIR, A et al. Type-2 pericytes participate in normal and tumoral angiogenesis. Am J Physiol Cell Physiol.; 307(1): C25-C38. Published. doi: 10.1152/ajpcell.00084. 2014.

BRAGA, I. Câncer de pâncreas. Disponível em: http://pt.slideshare.net/lgorThBraga/cncer-depncreas-33540865.2014.

BRAJSA, K. et al. Antitumor activity of amidino-substituted benzimidazole and benzimidazo[1,2a] quinoline derivatives tested in 2D and $3 D$ cell culture systems. 

2017). https://doi.org/10.3109/14756366.2015.1101093. 2015.

BRASÓ-MARISTANY, F. et al. PIM1 kinase regulates cell death, tumor growth and chemotherapy response in triple-negative breast câncer. Nature Medicine. 22, 1303-1313 doi:10.1038/nm.4198. 2016.

CANCER CELL LINE ENCYCLOPEDIA disponível em: https://portals.broadinstitute.org/ccle/data/mutationTagcloud/116/

CARR, D. et al. A Farnesyltransferase Acts to Inhibit Ectopic Neurite Formation in C. elegans. PLOS ONE, 11(6), 1-15. https://doi.org/10.1371/journal.pone.0157537. 2016.

ChAMBERS, A. F.; GROOM, A. C.; MACDONALD, I. C. Dissemination and growth of cancer cells in metastatic sites. Nature reviews. Cancer, v. 2, n. 8, p. 563-72, 2002.

CHAO P. et al. Development of a HPLC method to determine 5-fluorouracil in plasma: application in pharmacokinetics and steady-state concentration monitoring. Development of a HPLC method to determine 5-fluorouracil in plasma: application in pharmacokinetics and steady-state concentration monitoring. 2014.

CHANG, M. et al. Role of T cells and adherent cells in agerelated decline in murine interleukin 2 production. J. Immunol. 129, 2426. 1982.

CHEN, J. et al. Amplification of HER2 and TOP2A and deletion of TOP2A genes in a series of Taiwanese breast cancer. Medicine (United States), 96(2). https://doi.org/10.1097/MD.0000000000005582. 2017.

CHENG, G, et al. Lipopolysaccharide-induced $\alpha$-catenin downregulation enhances the motility of human colorectal cancer cells in an NF- K B signaling-dependent manner, 7563-7571. 2016.

COLEMAN, W. B. Obesity and the breast cancer methylome. Current Opinion in Pharmacology, 31, 104-113. https://doi.org/10.1016/j.coph.2016.11.006. 2016.

COOPER, G. M. "Cellular transforming genes". Science. 217 (4562): $801-6.1982$.

COX, A. D. et al. Drugging the undruggable RAS: Mission Possible? Nature reviews. Drug discovery, v. 13, n. 11, p. 828-51, 2014.

DABBS, D. J.; SILVERMAN, J. F. Immunohistochemical Workup of Metastatic Carcinoma of Unknown Primary. Pathology Case Reviews, v. 6, n. 4, p. 146-153, jul. 2001.

DI LEO, A. et al. HER-2 amplification and topoisomerase llalpha gene aberrations as predictive markers in node-positive breast cancer patients randomly treated either with an anthracyclinebased therapy or with cyclophosphamide, methotrexate, and 5-fluorouracil. Clinical cancer 
research: an official journal of the American Association for Cancer Research, v. 8, n. 5, p. 1107-16, 2002.

DRY, J. R., YANG, M., \& SAEZ-RODRIGUEZ, J. Looking beyond the cancer cell for effective drug combinations. Genome Medicine, 8(1), 125. https://doi.org/10.1186/s13073-016-0379-8. 2016.

FERLAY, J. et al. GLOBOCAN 2012 v1.0, Cancer Incidence and Mortality Worldwide: IARC Cancer Base No. 11. Lyon, France: International Agency for Research on Cancer; 2013.

FIDLER, I. J. The pathogenesis of cancer metastasis: the "seed and soil" hypothesis revisited. Nature reviews. Cancer, v. 3, n. 6, p. 453-8, 2003.

FRIEDL, P.; ALEXANDER, S. Review Cancer Invasion and the Microenvironment: Plasticity and Reciprocity. Cell, v. 147, n. 5, p. 992-1009, 2011.

FRIEDL, P.; WOLF, K. Tumour-cell invasion and migration: diversity and escape mechanisms. Nature reviews. Cancer, v. 3, n. 5, p. 362-74, 2003.

GAO, D. et al. The clinical value of aberrant epigenetic changes of DNA damage repair gen es in human cancer. Oncotarget, 7(24), 37331-37346. https://doi.org/10.18632/oncotarget.7949. 2016.

GLOBOCAN 2012: estimated cancer incidence, mortality and prevalence worldwide in 2012. Lyon, France: IARC; 2013. Disponível em: http://globocan.iarc.fr/. 2012.

GOMES, A. et al. Promoter hypermethylation of DNA repair genes $\mathrm{MLH} 1$ and MSH2 in adenocarcinomas and squamous cell carcinomas of the lung. Revista portuguesa de pneumologia, v. 20, n. 1, p. 20-30, [s.d.]. 2014.

GUIDO, B. C. Avaliação da atividade antitumoral dos derivados da 3,4- dihidropirimidinona (DHPMs) sobre células do adenocarcinoma mamário humano, 138 f. Tese (Doutorado em Patologia Molecular) - Universidade de Brasília, Brasília. 2014.

GURTOWSKA, N.; KLOSKOWSKI, T.; DREWA, T. Ciprofloxacin criteriain antimicrobial prophylaxis and bladder cancer recurrence. Medical Science Monitor, v. 16, n.10, p. RA218-223, 2010.

HALFTER, K. et al. Prospective cohort study using the breast cancer spheroid model as a predictor for response to neoadjuvant therapy - the SpheroNEO study. BMC Cancer, 1-10. https://doi.org/10.1186/s12885-015-1491-7. 2015.

HANAHAN, D.; WEINBERG, R. A. Hallmarks of cancer: the next generation. Cell, v. 144, n. 5, p. $646-674,2011$.

HARVEY, JJ. "Na unidentifield vírus which causes the rapid production of tumors in mice". Nature. 204 (4963): 1104-5. 1964. 
HEEB, S. et al,. Quinolones: From antibiotics to autoinducers. FEMS Microbiology Reviews, 35(2), 247-274. http://doi.org/10.1111/i.1574-6976.2010.00247.x. 2011.

HOLDENRIEDER, S. et al. Clinically Meaningful Use of Blood Tumor Markers in Oncology. BioMed Research International, 2016, 1-10. https://doi.org/10.1155/2016/9795269. 2016.

HOLTOM, P. D.; PAVKOVIC, S. A.; BRAVOS, P. D. et al. Inhibitory effects of the quinolone antibiotics trovafloxacin, ciprofloxacin, and levofloxacin on osteoblastic cells in vitro. Journal of Orthopaedic Resarch, v.18, p. 721-27, 2000.

HOOPER, D. C. Emerging mechanisms of fluoroquinolone resistance. Emerging Infectious Diseases, 7(2), 337-341. http://doi.org/10.3201/eid0702.010239. 2001.

HUANG, Y. et al. A 5-fluorouracil-loaded floating gastroretentive hollow microsphere: Development, pharmacokinetic in rabbits, and biodistribution in tumor-bearing mice. Drug Design, Development and Therapy, 10, 997-1008. https://doi.org/10.2147/DDDT.S97735. 2016.

INCA. Tipos de câncer. Rio de Janeiro, Disponível em: http://www2.inca.gov.br/wps/wcm/connect/tiposdecancer/site/home/pancreas. 2016.

JEMAL, A. et al. Global cancer statistics. CA Cancer J Clin, v. 61, n. 2, p. 69-90, 2011.

JONES, P. A; BAYLIN, S. B. The fundamental role of epigenetic events in cancer. Nature reviews. Genetics, v. 3, n. 6, p. 415-28, jun. JournalofOrthopaedicResarch, v.18, p. 721-27, 2002.

KANDOTH, C. et al. Mutational landscape and significance across 12 major cancer types. Nature, v. 502, n. 7471 , p. 333-9, 17 out. 2013.

KAUR, M. et al. Pancreatic Tuberculosis with Markedly Elevated CA 19-9 Levels: A Diagnostic Pitfall. Oman Medical Journal, 31(6), 446-449. https://doi.org/10.5001/omj.2016.89. 2016.

KHAN, N. A. et al. Identification of drugs that restore primary cilium expression in cancer cells. Oncotarget, 7(9), 9975-92. https://doi.org/10.18632/oncotarget.7198. 2016.

KIRCHNER, T. et al. Metaplasia, intraepithelial neoplasia and early cancer of the stomach are related to dedifferentiated epithelial cells defined by cytokeratin-7 expression in gastritis. Virchows Archiv, v. 439, n. 4, p. 512-522, 5 fev. 2014.

KIRSTEN, W. H. et al. "Properties of a murine sarcoma vírus". Bibl. Haematol (36): 246-9. 1970.

KOCSIS, B., DOMOKOS, J., \& SZABO, D. Chemical structure and pharmacokinetics of novel quinolone agents represented by avarofloxacin, delafloxacin, finafloxacin, zabofloxacin and nemonoxacin. Annals of Clinical Microbiology and Antimicrobials, 15, 34. https://doi.org/10.1186/s12941-016-0150-4. 2016 
KUMAR, D. et al. Therapeutic implications of cellular and molecular biology of cancer stem cells in melanoma. Molecular Cancer, 16(1), 7. https://doi.org/10.1186/s12943-016-0578-3. 2017.

LAKHANI, A. et al Efficacy of Triple Antibiotic Paste, Moxifloxacin, Calcium Hydroxide And 2\% Chlorhexidine Gel In Elimination of E. Faecalis: An In vitro Study. Journal of Clinical and Diagnostic Research, 11(1), 9-12. https://doi.org/10.7860/JCDR/2017/22394.9132. 2017.

$\mathrm{LI}$, D. et al. Regulation of DNA methyltransferase 1 transcription in BRCA1-mutated breast cancer: A novel crosstalk between E2F1 motif hypermethylation and loss of histone $\mathrm{H} 3$ lysine 9 acetylation. Molecular cancer, v. 13, n. 1, p. 26, 6 fev. 2014.

LIU, M. et al. Inhibition of Neoplastic Transformation and Chemically-Induced Skin Hyperplasia in Mice by Traditional Chinese Medicinal Formula Si-Wu-Tang. Nutrients, 9(3), 300. https://doi.org/10.3390/nu9030300. 2017.

LIZARAZO, R.; JORGE IVÁN. Patogénesis del cáncer de páncreas. Rev Col Gastroenterol, Bogotá, v. 23, n. 4, Dec. 2008.

LUNKE, S. et al. Intratumorous heterogeneity for RAS mutations in a treatment-naïve colorectal tumour. Journal of Clinical Pathology, jclinpath-2017-204327. https://doi.org/10.1136/jclinpath2017-204327. 2017.

MALUMBRES, M.; BARBACID, M. "RAS oncogenes: the first 30 years". Nat. Ver. Cancer. 3 (6): 459- 65 Chang EH, Gonda MA, Ellis RW, Scolnick EM, Lowy DR (Augut 1982). "Human genome contains four genes homologous to transforming genes of Harvey and Kirsten murine sarcoma viroses". Proc. Natl. Acad. Sci. U.S.A. 79. 2003.

MANTRIPRAGADA, K. et al. Telomerase Activity is a Biomarker for High Grade Malignant Peripheral Nerve Sheath Tumors in Neurofibromatosis Type 1 Individuals. Genes, Chromosomes \& Cancer, 47(April), 238-246. https://doi.org/10.1002/gcc. 2015

MAO, Y. et al. The expression of aplysia ras homolog I (ARHI) and its inhibitory effect on cell biological behavior in esophageal squamous cell carcinoma. Onco Targets Ther. 2017 Feb 27;10:1217-1226. doi: 10.2147/OTT.S125742. eCollection 2017.

MARCHI, G. D. E., PAIELLA, S., \& LUCHINI, C. Very high serum levels of CA 19-9 in autoimmune pancreatitis: report of 4 cases and brief review of literature. https://doi.org/10.1111/1751-2980.12403. 2016.

MCCARREY, J. et al. Tertiary Epimutations - A Novel Aspect of Epigenetic Transgenerational Inheritance Promoting Genome Instability. Plos One, 11(12), e0168038. https://doi.org/10.1371/journal.pone.0168038. 2016. 
MEACHAM, C. E. \& MORRISON, S. J. Tumour heterogeneity and cancer cell plasticity. Nature, 501(7467), 328-37. https://doi.org/10.1038/nature12624. 2014.

MELCHIONNA, $R$. et al. The pattern of hMENA isoforms is regulated by TGF-beta1 in pancreatic cancer and may predict patient outcome. Oncolmmunology, 5(12), no pagination. https://doi.org/10.1080/2162402X.2016.1221556. 2016.

MENG, X. et al. A new hypothesis for the cancer mechanism. Cancer metastasis reviews, v.31, n. 1-2, p. 247-68, jun. 2012.

MIYAZAKI, T. et al. Molecular Characteristics of Pancreatic Ductal Adenocarcinomas with HighGrade Pancreatic Intraepithelial Neoplasia (PanIN) Are Different from Those without High-Grade PanIN. Pathobiology https://doi.org/10.1159/000455194. 2017.

NAGY, Á. et al. KRAS driven expression signature has prognostic power superior to mutation status in non-small cell lung cancer. International Journal of Cancer, 937, 930-937. https://doi.org/10.1002/ijc.30509. 2016.

NORRIS, A. et al. AGR2 is a SMAD4-suppressible gene that modulates MUC1 levels and promotes the initiation and progression of pancreatic intraepithelial neoplasia. Oncogene,32(33),3867-3876.onc.2012.394, 2013.

NOVAK, K. Epigenetics Changes in Cancer Cells. Medscape General Medicine, v. 6, n. 4, 2004.

OEHHA. PROP 65. Chemicals known to the state to cause cancer or reproductive toxicity. State of California Environmental Protection Agency, Office of Environmental Health Hazard Assessment safe drinking water and toxic enforcement act of 1986. 2017.

PARK, J.et al. Allosterically Inhibited By Its Own Product, 1-8. https://doi.org/10.1038/ncomms14132. 2016.

PIMMIER, Y. et al. "DNA topoisomerases and their poisoning by anticâncer and antibacterial drigs". Chem. Biol. 17: 421-433. 2010.

PRESS, D. Biomarkers in pancreatic adenocarcinoma: current perspectives, 7459-7467. https://doi.org/10.2147/OTT.S100510. 2016.

QANDIL, A. M. et al. "Synthesis, Antibacterial Evaluation and QSAR of A-Substituted- $N_{4}$ Acetamides of Ciprofloxacin and Norfloxacin." Antibiotics 3.3 (2014): 244-269. PMC. Web. 27 Mar. 2017.

RAJASEKHARAN, S.; RAMAN, T. Ras and Ras mutations in cancer. Open LifeSciences, v. 8, n. 7, p. 609-624, 2013.

RANG, H. P.; DALE, M. M.; RITTER, J. M.; FLOWER, R. J.; HENDERSON, G. Rang \& Dale: 
farmacologia. Rio de Janeiro: Elsevier, cap.52,778p., 2011.

RAO, S. et al. A dual role for autophagy in a murine model of lung cancer. Nature communications, v. 5, p. 3056, 20 jan. 2014.

RIBATTI, D. Anti-angiogenesis in neuroblastoma. Critical reviews in oncology/hematology, v. 86, n. 3, p. 212-21, 2013.

RIESCO, A. et al. Epidermal Growth Factor Signaling towards Proliferation: Modeling and Logic Inference Using Forward and Backward Search, https://doi.org/10.1155/2017/1809513. 2017.

RÖDEROVA, M. et al. Characteristics of Quinolone Resistance in Escherichia coli Isolates from Humans, Animals, and the Environment in the Czech Republic. Frontiers in Microbiology, 7 (January), 1-12. https://doi.org/10.3389/fmicb.2016.02147. 2017.

RUCKI, A. et al. Heterogeneous stromal signaling within the tumor microenvironment controls the metastasis of pancreatic cancer. Cancer Research, 169702(18), 41-53. https://doi.org/10.1158/0008-5472.CAN-16-1383. 2016.

SAHAI, E. Illuminating the metastatic process. Nature reviews. Cancer, v. 7, n. 10, p.737-49, 2007.

SANTARPIA, M. KRAS driven expression signature has prognostic power superior to mutation status in non-small cell lung cancer, 937, 930-937. https://doi.org/10.1002/ijc.30509. 2017.

SANTIAGO-TIRADO, F.; DOERINGT, T. L. All about that fat: Lipid modification of proteins in Cryptococcus neoformans. HHS Public Access, 8(5), 583-592. https://doi.org/10.1002/aur.1474.Replication. 2016.

SARKER, P. et al. Ciprofloxacin Affects Host Cells by Suppressing Expression of the Endogenous Antimicrobial Peptides Cathelicidins and Beta-Defensin-3 in Colon Epithelia. Antibiotics, 3(3), 353-374. http://doi.org/10.3390/antibiotics3030353. 2014.

SCHINDELIN, J.; ARGANDA-CARRERAS, I. \& FRISE, E. et al. "Fiji: an open-source platform for biological-image analysis", Nature methods 9(7): 676-682, PMID 22743772 (on Google Scholar). 2012.

SEER Training Modules, Cancer Classification. U.S. National Institutes of Health, National Cancer Institute. 10/02/2014. <http://training.seer.cancer.gov/>. 2014.

SHEN, M. et al. Farnesyltransferase and geranylgeranyltransferase I: Structures, mechanism, inhibitors and molecular modeling. Drug Discovery Today, 20(2), 267-276. http://doi.org/10.1016/j.drudis. 2014. 
SINGH, D. et al. Effects of Topical Icing on Inflammation, Angiogenesis, Revascularization, and Myofiber Regeneration in Skeletal Muscle Following Contusion Injury. Frontiers in Physiology, 8(March), 1-15. https://doi.org/10.3389/fphys.2017.00093. 2017.

STOJANOVIC, $N$. et al. HDAC1 and HDAC2 integrate the expression of p53 mutants in pancreatic cancer. Nature Publishing Group, (April 2015), 1-12. https://doi.org/10.1038/onc.2016.344. 2015.

STYLIANOPOULOS, T. The solid mechanics of cancer and strategies for improved therapy. Journal of Biomechanical Engineering (in Press), 139(2), 1-23. https://doi.org/10.1115/1.4034991. 2016

SUN, J. P. et al. Trimethoxy-benzaldehyde levofloxacin hydrazone inducing the growth arrest and apoptosis of human hepatocarcinoma cells. Cancer Cell International, 13(1), 67. https://doi.org/10.1186/1475-2867-13-67. 2013.

SUN, Y., ZHANG, J., \& MA, L. alpha-catenin: A tumor suppressor beyond adherens junctions. Cell Cycle, 13(15), 2334-2339. https://doi.org/10.4161/cc.29765. 2014.

SZOPA, W. et al. Diagnostic and Therapeutic Biomarkers in Glioblastoma: Current Status and Future Perspectives, 2017. https://doi.org/10.1155/2017/8013575. 2017.

TIROSH I. et al. Dissecting the multicellular ecosystem of metastatic melanoma by single-cell RNA-seq. Science. 2016;352:189-196. doi: 10.1126/science.aad0501. 2016.

TODD, R.; WONG, D. T. Oncogenes. Anticancer research, v. 19, n. 6A, p. 4729-46, 1999.

TRANG et al. Genes \& Cancer, 2(3) 359-372, V. 4 ed. [s.I.] SAGE, 2013.

TRAVIS, W. D. et al. Histological Typing of Lung and Pleural Tumours. Berlin, Heidelberg: Springer Berlin Heidelberg, 1999.

UCHIHARA, T. et al. Recurrence 11 years after complete response to gemcitabine, 5Fluorouracil, and Cisplatin chemotherapy followed by radiotherapy in a patient with advanced pancreatic cancer: a case report. Anticancer research, v. 35, n. 5, p. 2867-2871, 2015.

UHR, $\mathrm{K}$, et al. Understanding drugs in breast cancer through drug sensitivity screening. SpringerPlus, 4, 611. https://doi.org/10.1186/s40064-015-1406-8, 2015.

VARGA, A. et al. RAF1/BRAF dimerization integrates the signal from RAS to ERK and ROKa. Sci. Signal. 07 Mar 2017: Vol. 10, Issue 469, eaai8482 DOI: 10.1126/scisignal.aai8482. 2017. VASAN, N., BOYER, J. L., \& HERBST, R. S. A RAS renaissance: Emerging targeted therapies for KRAS-mutated non-small cell lung cancer. Clinical Cancer Research, 20 (15), 3921-3930. http://doi.org/10.1158/1078-0432.CCR-13-1762. 2014. 
VETTER, I.; WITTINGHOFER, A. The Guanine Nucleotide-Binding Switch in three Dimensions. Science, Vol. 294 no. 5545 pp. 1299-1304, 2001.

VRIZ, S.; REITER, S.; GALLIOT, B. Cell death: a program to regenerate. Current topics in developmental biology, v. 108, p. 121-51, 2014.

WANG, N.; SWITALSKA, M.; WU, M.-Y.; et al. Synthesis and in vitro cytotoxic effect of 6-aminosubstituted $11 \mathrm{H}$ - and $11 \mathrm{Me}$-indol o [3,2-c] quinolines. European journal of medicinal chemistry, v. $78 \mathrm{C}$, p. $314-323,2014$.

WEINBERG, R. The Biology of Cancer. New York: Garland Science, 2006.

WEINSTEIN, I. B.; JOE, A. K. Mechanisms of disease: Oncogene addiction--a rationale for molecular targeting in cancer therapy. Nature clinical practice. Oncology, v. 3, n. 8, p. 448-57, ago. 2006.

WHO. II "Neoplasms". World Health Organization. Retrieved 19 June 2014.

YADAV, V.et al. Moxifloxacin and ciprofloxacin induces S-phase arrest and augments apoptotic effects of cisplatin in human pancreatic cancer cells via ERK activation. BMC Cancer, 15, 581. https://doi.org/10.1186/s12885-015-1560-y. 2015.

YANG, Z. J. et al. Autophagy modulation for cancer therapy. Cancer biology \& therapy, v. 11, n. 2, p. 169-76, 15 jan. 2011.

YU, D. et al. Targeted p16/nk4a epimutation causes tumorigenesis and reduces survival in mice. The Journal of Clinical Investigation, v. 124, n. 9, p. 3708-3712, 2014.

ZHANG, M. et al. A simple microfluidic strategy for cell migration assay in an in vitro woundhealing model. Wound repair and regeneration: official publication of the Wound Healing Society [and] the European Tissue Repair Society, 17 out. 2013.

ZHAO, B. et al. Addressing Genetic Tumor Heterogeneity through Computationally Predictive Combination Therapy. Cancer discovery, v. 4, n. 2, p. 166-74, fev. 2014.

ZHU, Z. et al. Mutations in the p16 gene in DMBA-induced pancreatic intraepithelial neoplasia and pancreatic cancer in rats. Hepatobiliary and Pancreatic Diseases International, 14(2), 208214. https://doi.org/10.1016/S1499-3872(15)60331-9. 2015. 